\section{OAK RIDGE NATIONAL LABORATORY}
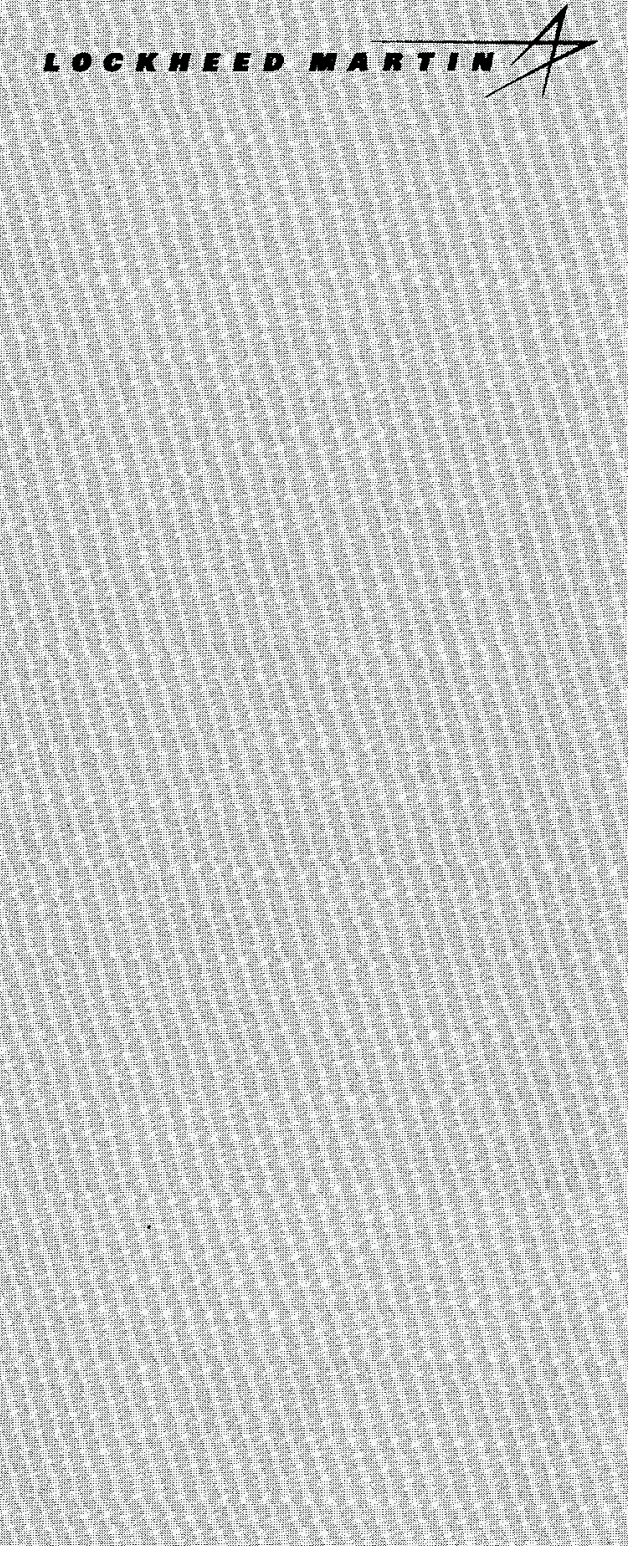

VAYAGED AND OPERATED BY WOCKHEED WARTH ENERGY RESEAROH CORPORATHON FORTHEUMTED STATES DEPAFTHENT OF ENEREY

\section{Characterization of the C1 \& C2 Waste Tanks Located in the BVEST System at ORNL}

J. M. Keller

J. M. Giaquinto

\section{MASTER}

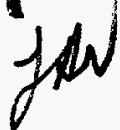


This report has been reproduced directly from the best available copy.

Available to DOE and DOE contractors from the Office of Scientific and Technical Information, P.O. Box 62, Oak Ridge, TN 37831; prices available from (423) 576-8401, FTS 626-8401.

Available to the public from the National Technical Information Service, U.S. Department of Commerce, 5285 Port Royal Rd., Springfield, VA 22161.

This report was prepared as an account of work sponsored by an agency of the United States Government. Neither the United States Government nor any agency thereof, nor any of their employees, makes any warranty, express or implied, or assumes any legal liability or responsibility for the accuracy, completeness, or usefulness of any information, apparatus, product, or process disclosed, or represents that its use would not infringe privately owned rights. Reference herein to any specific commercial product, process, or service by trade name, trademark, manufacturer, or otherwise, does not necessarily constitute or imply its endorsement, recommendation, or favoring by the United States Government or any agency thereof. The views and opinions of authors expressed herein do not necessarily state or reflect those of the United States Government or any agency thereof. 


\section{DISCLAIMER}

Portions of this document may be illegible electronic image products. Images are produced from the best available original document. 


\title{
Characterization of the C1 \& C2 Waste Tanks Located in the BVEST System at ORNL
}

\author{
J. M. Keller \\ J. M. Giaquinto
}

February 1998

\author{
Prepared by the \\ OAK RIDGE NATIONAL LABORATORY \\ Oak Ridge, Tennessee 37831 \\ managed by \\ LOCKHEED MARTIN ENERGY RESEARCH CORP. \\ for the \\ U.S. DEPARTMENT OF ENERGY \\ under contract \\ DE-AC05-96OR22464
}




\section{TABLE OF CONTENTS}

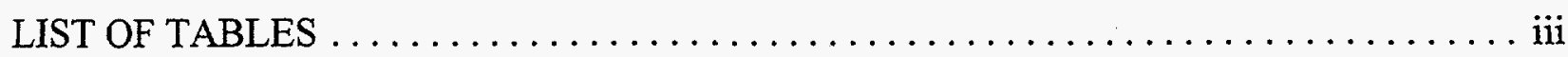

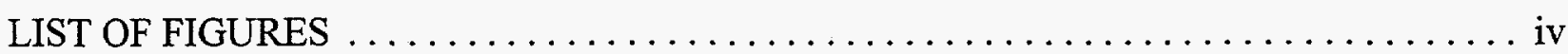

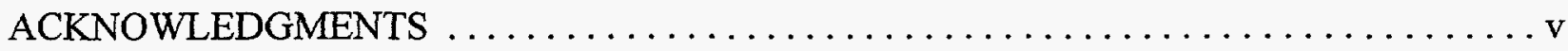

ABBREVIATIONS AND ACRONYMS $\ldots \ldots \ldots \ldots \ldots \ldots \ldots \ldots \ldots \ldots \ldots \ldots \ldots$ vi

EXECUTIVE SUMMARY $\ldots \ldots \ldots \ldots \ldots \ldots \ldots \ldots \ldots \ldots \ldots \ldots \ldots \ldots$ vii

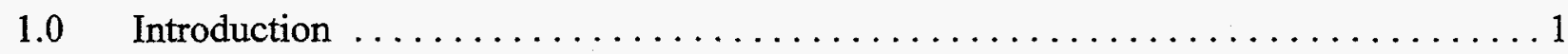

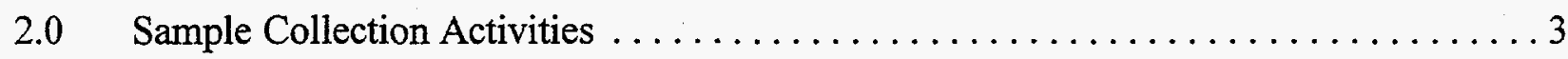

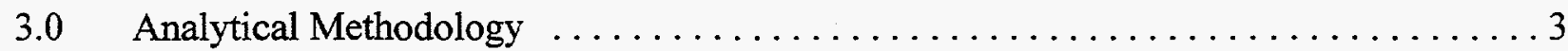

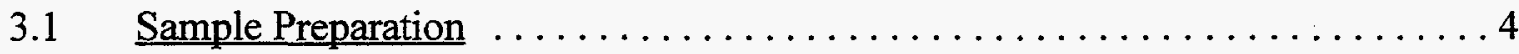

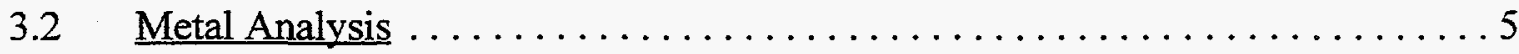

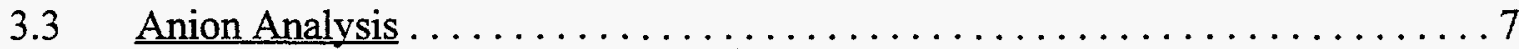

3.3.1 Microwave Digestion for the Analysis of Phosphate and Sulfate . . . . . 8

3.3.2 Caustic Fusion Method $\ldots \ldots \ldots \ldots \ldots \ldots \ldots \ldots \ldots \ldots$

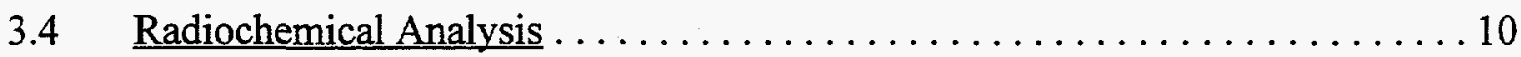

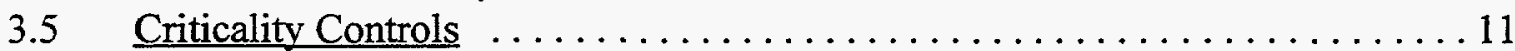

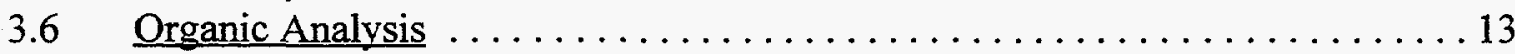

3.6.1 Non-halogenated Volatile Organic Analysis (NHVOA) . . . . . . . 13

3.6.2 Volatile Organic Analysis (VOA) ........................ 14

3.6.3 Semivolatile Organic Analysis (SVOA) $\ldots \ldots \ldots \ldots \ldots \ldots \ldots \ldots \ldots \ldots \ldots \ldots$

3.6.4 Polychlorinated Biphenyls (PCB) $\ldots \ldots \ldots \ldots \ldots \ldots \ldots \ldots \ldots \ldots \ldots \ldots$

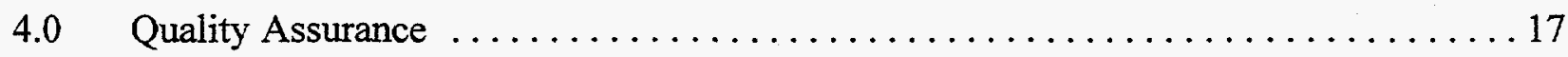

5.0 Summary of Inorganic and Radiochemical Analytical Results $\ldots \ldots \ldots \ldots \ldots \ldots 18$

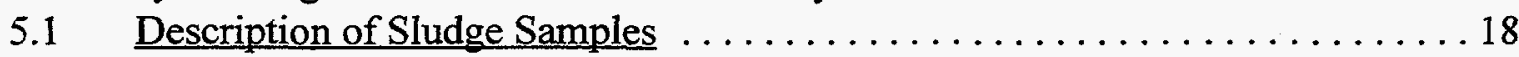

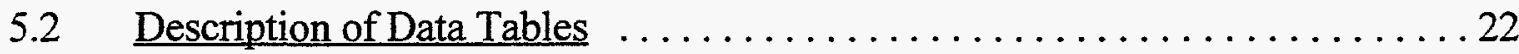

5.3 Discussion of $\mathrm{C} 1$ and $\mathrm{C} 2$ Supernatant Characteristics $\ldots \ldots \ldots \ldots \ldots \ldots 33$

5.4 Discussion of $\mathrm{C} 1$ and $\mathrm{C} 2$ Sludge Characteristics $\ldots \ldots \ldots \ldots \ldots \ldots \ldots \ldots$

5.5 RCRA Characteristics for the $\mathrm{C} 1$ and $\mathrm{C} 2$ Sludge $\ldots \ldots \ldots \ldots \ldots \ldots \ldots$

5.6 TRU Classifications for $\mathrm{C} 1$ and $\mathrm{C} 2$ Sludge $\ldots \ldots \ldots \ldots \ldots \ldots \ldots \ldots \ldots$

5.7 Distribution of Fissile Material in $\mathrm{C} 1$ and $\mathrm{C} 2$ Sludge $\ldots \ldots \ldots \ldots \ldots \ldots 42$

5.8 Discussion of the Total Anion Content in the Sludge $\ldots \ldots \ldots \ldots \ldots \ldots 45$

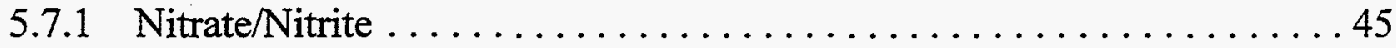

5.7.2 Halides (fluoride, chloride, bromide) . . . . . . . . . . . 46 


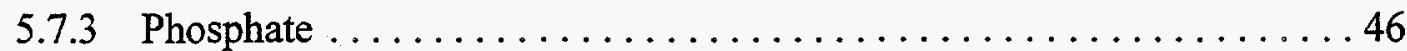

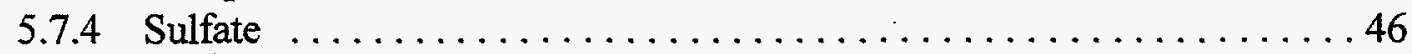

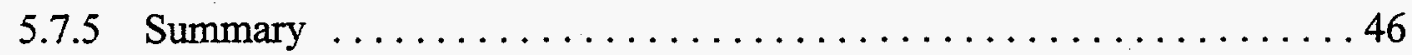

5.8 Estimates for Compliance with WIPP WAC, Rev. 5 for BVEST Sludge . . . . 47

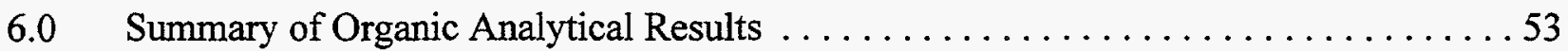

$6.1 \quad$ Discussion of Organic Analysis . .......................... 58

6.2 Regulatory Concerns due to Organic Compounds in Waste Tank Sludge . . . 58

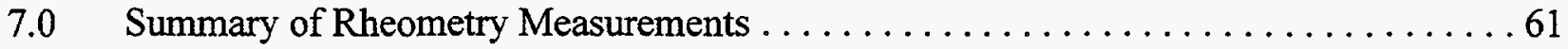

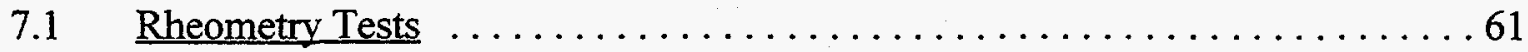

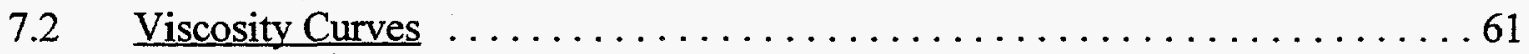

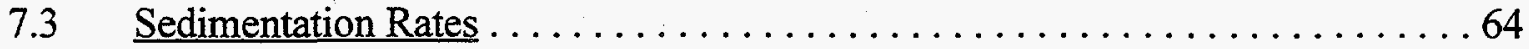

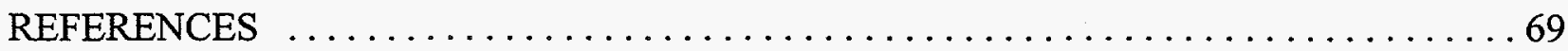

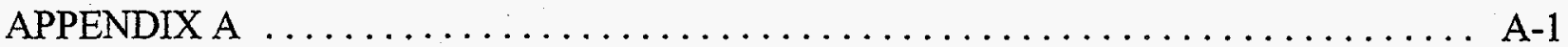

QC Acceptance Criteria for Radioactive Liquid/Solid Waste Samples .......... A-1

Volatile Organic Analyses QC Limits .................... A-4

Nonhalogenated Volatile Organic Analyses QC Limits ............ A-5

Semivolatile Organic Analyses QC Limits ................ A-5

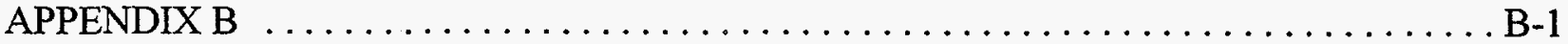

Table B1 Total Mass and Activity for Selected Species of Interest in Sludge . . B-2 


\section{LIST OF TABLES}

\section{Table}

Summary of Tanks in the Active ORNL LLLW System $\ldots \ldots \ldots \ldots \ldots \ldots \ldots 2$

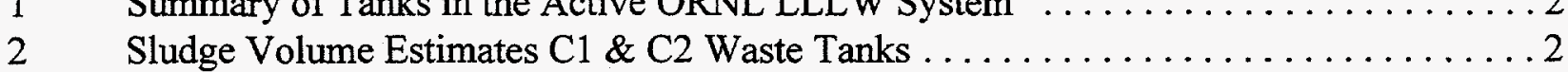

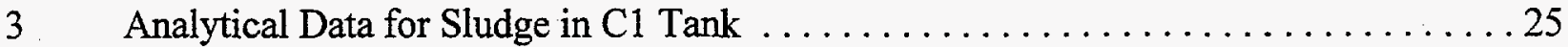

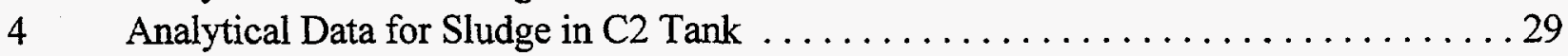

5 Assumptions Used for Major Compounds in Sludge ...................... 35

6 Summary of Quality Checks for C1 and C2 Sludge Data $\ldots \ldots \ldots \ldots \ldots \ldots \ldots \ldots$

$7 \quad$ Distribution of Beta Activity in Sludge ............................. 38

8 Summary of Actinide Elements in BVEST Sludge $\ldots \ldots \ldots \ldots \ldots \ldots \ldots \ldots \ldots \ldots \ldots$

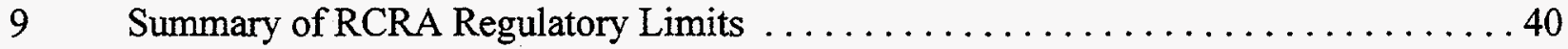

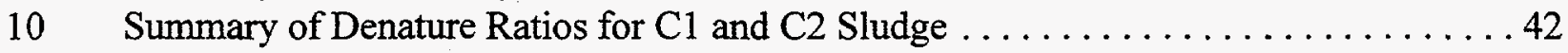

11 Example of Converting Atom $\%$ to Weight $\%$ for Typical Sludge $\ldots \ldots \ldots \ldots \ldots 43$

12 Summary of Total Anion Data for $\mathrm{C} 1$ and $\mathrm{C} 2$ Sludge $\ldots \ldots \ldots \ldots \ldots \ldots \ldots \ldots$

13 Estimates for ${ }^{239} \mathrm{Pu}$ FGE Content in the $\mathrm{C} 1$ and $\mathrm{C} 2$ Sludge $\ldots \ldots \ldots \ldots \ldots \ldots . \ldots . \ldots$

14 Estimates for ${ }^{239} \mathrm{Pu}$ Equivalent Activity with the BVEST Sludge . . . . . . . . . . . 49

15 Isotopes that Contribute to the Decay Heat in the $\mathrm{C} 1$ and $\mathrm{C} 2$ Sludge $\ldots \ldots \ldots \ldots \ldots 50$

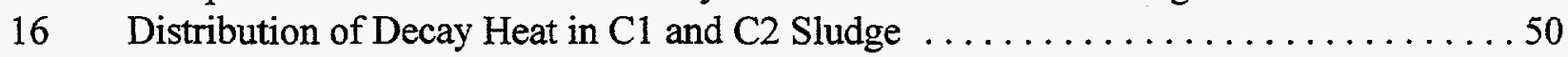

17 Summary of Relative Decay Heat in $\mathrm{C} 1$ and $\mathrm{C} 2$ Sludge $\ldots \ldots \ldots \ldots \ldots \ldots \ldots \ldots \ldots$

18 Analytical organic data for OHF sludge samples $\ldots \ldots \ldots \ldots \ldots \ldots \ldots \ldots \ldots$

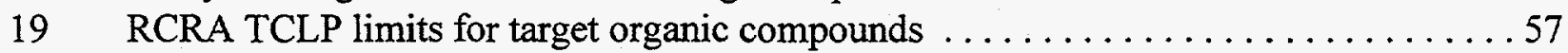




\section{LIST OF FIGURES}

Figure

Figure 1

Figure 2

Figure 3

Figure 4

Figure 5

Figure 6

Figure 7

Figure 8

Figure 9

Figure 10

Figure 11

Figure 12

Figure 13

Figure 14
Page

Photographs of C1-East and C1-West Core Samples ............... 19

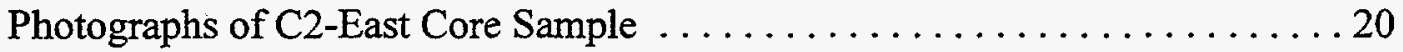

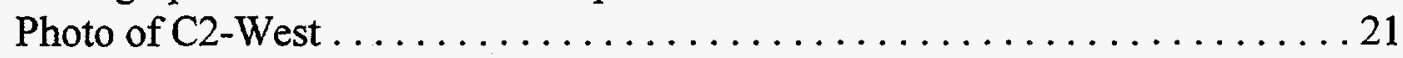

Distribution of Major Compounds in $\mathrm{C} 1$ and $\mathrm{C} 2$ Sludge ............. 37

Distribution of Uranium and Thorium in $\mathrm{C} 1$ and $\mathrm{C} 2$ Sludge ............. 37

Distribution of Plutonium Alpha Activity in the $\mathrm{C} 1$ and C2 Sludge ........ 44

Distribution of Plutonium by Concentration in the $\mathrm{Cl}$ and $\mathrm{C} 2$ Sludge ......44

Distribution of Beta Decay Heat in $\mathrm{C} 1$ and $\mathrm{C} 2$ Sludge $\ldots \ldots \ldots \ldots \ldots . \ldots 52$

Distribution of Alpha Decay Heat in C1 and C2 Sludge ............. 52

Apparent Viscosity for C2-East with $3.1 \%$ Suspended Solids $\ldots \ldots \ldots \ldots 63$

Apparent Viscosity for C2-East with $6.8 \%$ Suspended Solids $\ldots \ldots \ldots \ldots 63$

Illustration of Parameters used for Sedimentation Rate Experiments . . . . . . 66

Sedimentation Rates for $\mathrm{C} 1$ and $\mathrm{C} 2$ Sludge During the First Five Hours . . . . 67

Sedimentation Rates for $\mathrm{C} 1$ and C2 Sludge for Several Days ...........67 


\section{ACKNOWLEDGMENTS}

The authors wish to express appreciation to the following staff members of the ORNL Chemical and Analytical Sciences Division who made important contributions to this work:

Inorganic and Radiochemical Analytical Support

L. D. Bible

R. D. Canaan

D. A. Caquelin

E. H. McBay

A. M. Meeks

T. P. Mills ${ }^{\mathrm{a}}$

D. H. Smith

N. A. Teasley

Organic Analytical Support

S. H. Harmon

R. L. Schenley

${ }^{a}$ Subcontractor staff, Kelly Scientific Services.

The authors also wish to express appreciation to the following staff members of the Liquid and Gaseous Waste Operation Section of the Waste Management and Remedial Actions Division for tank sampling support:

Sampling Radioactive Waste Tanks

J. D. Brewer

C. B. Scott 


\section{ABBREVIATIONS AND ACRONYMS}

$\begin{array}{ll}\text { ALARA } & \text { As Low As Reasonably Achievable } \\ \text { BVEST } & \text { Bethel Valley Evaporator Service Tanks } \\ \text { CAO } & \text { Carlsbad Area Office } \\ \text { CASD } & \text { Chemical and Analytical Sciences Division } \\ \text { CVAA } & \text { Cold Vapor Atomic Absorption } \\ \text { DOT } & \text { Department of Transportation } \\ \text { DQO } & \text { Data Quality Objective } \\ \text { EPA } & \text { Environmental Protection Agency } \\ \text { GC/MS } & \text { Gas Chromatography/Mass Spectrometry } \\ \text { GC } & \text { Gas Chromatography } \\ \text { GFAA } & \text { Graphite Furnace Atomic Absorption } \\ \text { IC } & \text { Ion Chromatography } \\ \text { ICP } & \text { Inductively Coupled Plasma } \\ \text { ICP-AES } & \text { Inductively Coupled Plasma - Atomic Emission Spectroscopy } \\ \text { ICP-MS } & \text { Inductively Coupled Plasma - Mass Spectrometry } \\ \text { IDL } & \text { Instrument Detection Limit } \\ \text { LCS } & \text { Laboratory Control Sample } \\ \text { LGWO } & \text { Liquid and Gaseous Waste Operations } \\ \text { LLLW } & \text { Liquid Low-Level Waste } \\ \text { LMER } & \text { Lockheed Martin Energy Research, Corp. } \\ \text { LMES } & \text { Lockheed Martin Energy Systems, Inc. } \\ \text { MDL } & \text { Method Detection Limit } \\ \text { MS } & \text { Matrix Spike } \\ \text { MSD } & \text { Matrix Spike Duplicate } \\ \text { MVST } & \text { Melton Valley Storage Tanks } \\ \text { NHVOA } & \text { Non-halogenated Volatile Organic Analysis } \\ \text { NTS } & \text { Nevada Test Site } \\ \text { ORNL } & \text { Oak Ridge National Laboratory } \\ \text { PCB } & \text { Polychlorinated Biphenyls } \\ \text { QA } & \text { Quality Assurance } \\ \text { QAPjP } & \text { Quality Assurance Project Plan } \\ \text { QAPP } & \text { Quality Assurance Program Plan } \\ \text { QC } & \text { Quality Control } \\ \text { RCRA } & \text { Resource Conservation and Recovery Act } \\ \text { RMAL } & \text { Radioactive Materials Analytical Laboratory (Building 2026) } \\ \text { SVOA } & \text { Semivolatile Organic Analysis } \\ \text { TC } & \text { Total Carbon } \\ \text { TCLP } & \text { Toxicity Characteristic Leaching Procedure } \\ \text { TDS } & \text { Total Dissolved Solids } \\ \text { TIC } & \text { Total Inorganic Carbon or Tentatively Identified Compounds } \\ \text { TIMS } & \text { Thermal Ionization Mass Spectrometry } \\ \text { TOC } & \text { Total Organic Carbon } \\ \text { TRU } & \text { Transuranic } \\ \text { TWCP. } & \text { Transuranic Waste Characterization Program } \\ \text { VOA } & \text { Volatile Organic Analysis } \\ \text { WAC } & \text { Waste Acceptance Criteria } \\ \text { WIPP } & \text { Waste Isolation Pilot Plant } \\ & \end{array}$




\section{EXECUTIVE SUMMARY}

During the fall of 1996 there was a major effort to sample and analyze the Active Liquid Low-Level Waste (LLLW) tanks at ORNL which include the Melton Valley Storage Tanks (MVST) and the Bethel Valley Evaporator Service Tanks (BVEST). The characterization data summarized in this report was needed to address waste processing options, address concerns dealing with the performance assessment (PA) data for the Waste Isolation Pilot Plant (WIPP), evaluate the waste characteristics with respect to the waste acceptance criteria (WAC) for WIPP and Nevada Test Site (NTS), address criticality concerns, and meet DOT requirements for transporting the waste. This report discusses the analytical characterization data for the supernatant and sludge in the BVEST waste tanks C-1 and C-2. There are two companion reports on the MVST and BVEST waste tanks (ORNL/TM-13357 and ORNL/TM-13358, respectively) that includes the analytical data and discussion of the results for the supernatant and sludge found in the remaining active tanks.

The isotopic data presented in this report supports the position that fissile isotopes of uranium ${ }^{233} \mathrm{U}$ and ${ }^{235} \mathrm{U}$ ) and plutonium $\left({ }^{239} \mathrm{Pu}\right.$ and ${ }^{241} \mathrm{Pu}$ ) were "denatured" as required by the administrative controls stated in the ORNL LLLW waste acceptance criteria (WAC). In general, the sludge in tanks C1 \& C2 was found to be hazardous based on RCRA characteristics and the transuranic alpha activity was well above the $100 \mathrm{nCi} / \mathrm{g}$ limit for TRU waste. Additional characteristics of the $\mathrm{C} 1 \& \mathrm{C} 2$ sludge inventory relative to the WIPP WAC limits for fissile gram equivalent, plutonium equivalent activity, and thermal power from decay heat were estimated from the data in this report and found to be far below the upper boundary for any of the remote-handled transuranic waste (RH-TRU) requirements for disposal of the waste in WIPP. 


\title{
Characterization of the C1 \& C2 Waste Tanks Located in the BVEST System at ORNL
}

\author{
J. M. Keller and J. M. Giaquinto
}

\subsection{Introduction}

The predominate storage capacity of active ORNL Liquid Low Level Waste (LLLW) system consists of the set of waste tanks summarized in Table 1. As indicated in Table 1, this report discusses the analytical characterization data for the sludge in the BVEST waste tanks C-1 and C-2. There are three companion reports ${ }^{1-3}$ that include the characterization data for the remaining MVST and BVEST waste tanks. The characterization data summarized in this report was needed to address waste processing options, examine concerns from the performance assessment (PA) for the Waste Isolation Pilot Plant (WIPP), evaluate the waste characteristics with respect to the waste acceptance criteria (WAC) for WIPP and Nevada Test Site (NTS), deal with criticality concerns, and to meet DOT requirements for transporting the waste. Additional discussions of sludge and supernatant characteristics for most waste transferred to the active LLLW tanks located at ORNL can be found in reports ${ }^{4-10}$ on sampling campaigns done over the last ten years.

The data was collected during a sampling and analysis campaign performed during the late summer and fall of 1996. The sampling and waste characterization requirements were documented in a Sampling and Analysis Plan ${ }^{11}$ (SAP). The level of quality assurance approximates that required for regulatory measurements with the understanding that, when needed, sample size requirements were reduced, and steps were taken to reduce sample handling to ensure radiation exposures were aslow-as-reasonably-achievable (ALARA). Some procedure modifications were required to handle chemical matrix problems due to the high levels of sodium nitrate, uranium, and thorium present. Any deviations from procedures or problems observed with the tank samples were documented in the data files maintained by the laboratory. The regulatory holding time requirements for mercury and the organic measurements were complied with unless noted differently in the data tables. The Quality Control (QC) Acceptance Criteria for measurements used on this project are summarized in Appendix A. Total sludge inventory for selected species are estimated in Appendix B. 
Table 1 Summary of Tanks in the Active ORNL LLLW System

\begin{tabular}{||l|c|c|}
\hline \multirow{2}{*}{ Tanks } & \multicolumn{2}{|c|}{ Data Presented in this report } \\
\cline { 2 - 3 } & Liquid & Sludge \\
\hline \hline BVEST TANKS & $\checkmark$ & $\checkmark$ \\
\hline C-1 (HLW) & $\checkmark$ & $\checkmark$ \\
\hline C-2 (HLW) & none & none \\
\hline W-21 (PWTP) & none & none \\
\hline W-22 (BVCT) & none & none \\
\hline W-23 (LLLW) & none & none \\
\hline MVST TANKS & non & \\
\hline W-24 through W-31 &
\end{tabular}

Access manholes on the east and west ends of the C-1 and C-2 waste tanks were installed in the summer of 1997; prior to the installation of these new manholes there was no analytical data available to evaluate these tanks. An inventory of radioactive liquid waste and sludge stored in each tank when the samples were collected are shown in Table 2. The volume data is based on estimates ${ }^{12}$ provided by the Lockheed Martin Energy Systems (LMES) Engineering Department.

Table 2 Sludge Volume Estimates C1 \& C2 Waste Tanks

\begin{tabular}{|l||c||c|c||}
\hline \multicolumn{1}{|l||}{ Tank } & \multicolumn{1}{|c||}{$\begin{array}{c}\text { Sludge Depth } \\
\text { (in.) }\end{array}$} & \multicolumn{2}{c|}{ Sludge Volume } \\
\hline \hline C1-East & 6 & & (L) \\
C1-West & 13 & & 5680 \\
\hline C1-avg. & 10 & 1500 & \\
\hline \hline C2-East & 24 & & 17030 \\
C2-West & 16 & & \\
\hline C2-avg. & 20 & 4500 & \\
\hline
\end{tabular}




\subsection{Sample Collection Activities}

A detailed description on the background, operation of the LLLW system, and the sample collection techniques has been presented in previous reports and will not be discussed here (see Sections 2 and 3 of Reference 5). The staff from the Liquid and Gaseous Waste Operations (LGWO) Section provided all sample collection support and delivered the samples to the analytical laboratory. A good description of the sampling procedures is provided in the Sampling and Analysis Plan ${ }^{11}$; a current copy of these procedures are available from the LGWO Section. The documentation for chain-of-custody was prepared, maintained for each sample collected, and stored with the data files by the analytical laboratory.

\subsection{Analytical Methodology}

The information and data collected from these studies are used to support various activities. The activities include demonstration of regulatory compliance, measurements to support future processing options, and to meet data needs for risk assessments and other safety related assessments such as criticality. Standardized analytical procedures are used to the extent possible to ensure broad acceptance of the data generated. Unless stated otherwise, the U. S. Environmental Protection Agency (EPA) methods were used for the analyses of constituents listed as hazardous under the Resource Conservation and Recovery Act (RCRA), which includes all the inorganic and organic measurements presented in this report. In general the EPA Guidance Manual, Test Methods for Evaluating Solid Waste ${ }^{13}$ (SW-846), was used for inorganic and organic methods. Some modifications of the standard procedures were necessary to handle the high radiation levels and the high salt/solids content of the samples. Some procedure modifications were required to generate valid data; these changes were usually needed to correct for chemical or other matrix related interferences common to DOE generated liquid waste from nuclear processes. All deviations from the standard procedures are documented in the raw data files and can be provided upon request to data users. 


\subsection{Sample Preparation}

The aqueous supernatant samples from the waste tanks were filtered or centrifuged to remove suspended particles. The clarified liquids were then digested by the SW-846 Method 3015, Microwave Assisted Acid Digestion of Aqueous Samples and Extracts. This sample preparation for aqueous samples was then used for all subsequent metal analyses by ICP-AES and GFAA and most of the radiochemical analyses. Results from a collaborative study ${ }^{14}$ with Argonne National Laboratory - East (ANL-E) demonstrated Method 3015/3051 provided excellent recovery for mercury and was, therefore, used to prepare the tank samples for this project for mercury determination.

The primary method for digesting the sludge samples was SW-846 Method 3051, Microwave Assisted Acid Digestion of Sediments, Sludges, Soils, and Oils. This sample preparation is considered to be a total digestion for metals and radionuclides by regulatory agencies and yields good results for most metals and radionuclides of interest. This digestion gave poor performance on two of the metals of interest, silver and silicon. Although nitric acid is excellent for dissolving silver compounds, there is usually enough chloride present in waste samples to form an insoluble silver chloride $(\mathrm{AgCl})$ precipitate. If the chloride concentration is increased sufficiently, a silver chloride complex $\left(\mathrm{AgCl}_{3}^{-2}\right)$ forms which is soluble in the aqueous environment. Improved matrix spike recovery and defensible data for silver were obtained using a separate sample digestion discussed later in this report.

If the total silicon content in the sludge must be known to develop waste treatment options such as vitrification, another sample digestion is required. A simple nitric acid treatment will not dissolve most siliceous materials. The SW-846 Method 3052, Microwave Assisted Acid Digestion of Siliceous and Organically Based Matrices, provides the necessary digestion chemistry to yield good silicon data. Sludge samples were prepared for measurement of total silicon, by taking approximately $0.25-0.5 \mathrm{~g}$ of sludge and mixing with $7 \mathrm{~mL}$ of concentrated nitric acid and $3 \mathrm{~mL}$ of hydrofluoric acid in a fluorocarbon microwave vessel. The samples were digested using a power program which slowly raised the digestion temperatures to $175^{\circ} \mathrm{C}$ which was then held for at least 5 minutes and then cooled to room temperature. The acid solution was then treated with excess boric 
acid to complex any free fluoride. This digestion mixture was then filtered into a $50 \mathrm{~mL}$ volumetric flask and diluted to volume with ASTM Type II water. Care must be exercised to ensure the digestion solution is cooled to room temperature prior to opening the sealed microwave vessel or there may be a significant loss of the volatile $\mathrm{SiF}_{4}$. The free fluoride is complexed with the boron to protect the sample introduction system to the ICP-AES and to prevent a high silicon background from the instrument glassware. This sample digestion with hydrofluoric acid should not be used for radiochemical measurements, especially for measurement of lanthanides or actinides.

Most of the metal and radionuclide data presented in this report are based upon a Method 3051 digestion with approximately a 0.5 gram sludge sample and $10 \mathrm{~mL}$ of concentrated nitric acid. After the microwave digestion is completed and the solution cooled to room temperature, the sample is filtered into a volumetric flask and diluted to $50 \mathrm{~mL}$ with ASTM Type II water or better. To ensure valid silver and antimony data, samples were digested in a similar manner except the $10 \mathrm{~mL}$ of nitric acid was replaced with $6 \mathrm{~mL}$ of concentrated nitric acid plus $4 \mathrm{~mL}$ of concentrated hydrochloric acid. Any residue remaining after the nitric acid or nitric-hydrochloric acid digestion consisted of mostly $\mathrm{SiO}_{2}$ and was discarded.

\subsection{Metal Analysis}

Three analytical measurement methods were used to determine all of the metals included in this report. Most of the metals are first determined by SW-846 Method 6010A, Inductively Coupled Plasma-Atomic Emission Spectroscopy (ICP-AES). There are several elements of interest for which the ICP-AES has insufficient detection limits, and these elements must be determined by Method 7000A, Atomic Absorption Methods. The Radioactive Materials Analytical Laboratory (RMAL) uses

a Graphite Furnace Atomic Absorption (GFAA) Spectrometer for elements that require better sensitivity. The elements that may require GFAA were antimony (Method 7041), arsenic (Method 7060A), lead (Method 7421), selenium (Method 7740), and thallium (Method 7841). All the mercury measurements are done by either Method 7470A, Mercury in Liquid Waste (Manual ColdVapor Technique), or Method 7471A, Mercury in Solid or Semisolid Waste (Manual Cold-Vapor Technique). The samples discussed in this report were prepared for mercury analysis by the 
microwave technique discussed in section 3.1, the sample preparation specified in the mercury methods $(7470 \mathrm{~A}$ and $7471 \mathrm{~A})$ were not used.

The level of radioactivity in most LLLW tank samples required that the analytical systems used for metal measurements be modified for operation in a radiochemical hood or glove box. Custom instrument configurations are necessary to ensure contamination control and worker safety. All work was performed in radiochemical laboratories which are operated under strict radiation protection programs, with the use of protective clothing and routine contamination monitoring. Both an ICP-AES system and a GFAA system can generate dry, dusty particles which are difficult to contain and are highly hazardous when radioactive. A detailed description of the RMAL setup for these instruments are given in Appendix B of Reference 5.

The instrument detection limits (IDL) for various metals with undiluted aqueous samples are listed in data tables along with the results. For sludge samples, these detection limits must be increased by a factor that represents the dilution that results from the sample preparation. For all the BVEST sludge samples approximately $0.5 \mathrm{~g}$ of sample was digested and then diluted to $50 \mathrm{~mL}$ which results in about a 100 fold dilution for the sample, and thus a 100 fold increase in the detection limits.

The analytical error for the metal measurements depends upon the analytical method, the concentration level, and the chemical matrix. Inductively-coupled plasma-atomic emission spectroscopy (ICP-AES) and inductively coupled plasma-mass spectrometry (ICP-MS) are both multi-element measurement techniques that are designed for the best average performance for all elements analyzed. In general, these measurement techniques are not optimized for any single element. The sample introduction system for ICP instruments adds additional variability due to changes in sample density, viscosity, and solids content between samples and/or calibration standards. Overall, the expected analytical error for ICP measurements range from $\pm 4-6 \%$ at concentrations above 10 times the detection limit to $\pm 20-50 \%$ near the detection limit. These error estimates are typical for both ICP-AES and ICP-MS measurements.

Graphite Furnace AA instruments are generally optimized for a specific element and usually provide lower detection limits and better precision. The expected analytical error for GFAA measurements 
range from $3-5 \%$ for concentrations greater than 10 times the detection limit to $20-40 \%$ near the detection limit. One advantage of GFAA analysis is that the measurements are normally well above the method's detection limits. The mercury measurements were done by Cold Vapor Atomic Absorption (CVAA), which is very selective and sensitive for mercury. The analytical errors for CVAA measurements are similar to GFAA work.

\subsection{Anion Analysis}

The determination of the inorganic anions was needed for the development of process treatment options, to provide information to explain the distribution and chemical behaviors observed in the waste tanks, and to ensure the major chemical constituents were identified in the waste for which data was used to calculate the mass and charge balance for each sample. The common inorganic anions; including fluoride, chloride, bromide, phosphate, nitrate, nitrite, and sulfate; were measured by ion chromatography (IC) with a Dionex Model 4500i system using either a Dionex AS14 or AS11 analytical column. In addition, several water soluble organic acids were measured along with the inorganic anions. These organic acids were measured in their ionized form and included formate, acetate, citrate, and oxalate. Both the citrate and the oxalate can form strong complexes with many metals and change the solution chemistry of these metals in the waste. The ion chromatography system used for measurements on these radioactive samples was configured such that the components that come into contact with radioactivity were isolated in a radiochemical hood for contamination control.

From past observations, the nitrate content usually dominates both the mass and charge balance calculations with both the supernatant and sludge samples taken from the active LLLW tanks. There are many other anions present in the waste, some of which are measured directly by ion chromatography and others which can be estimated from the metal data such as chromate, dichromate, permanganate, and others. The carbonate is estimated from the total inorganic carbon measurement.

The performance of balance checks for sludge samples is not expected to be as good as the liquid samples because of the large content of mixed oxides, hydrated hydroxides (heavy metals and 
actinides), and insoluble carbonates (calcium carbonate, etc.) present in the sludge. The complex precipitation chemistry of the sludge complicates the measurements of total anions and makes estimates for the mass and charge balance more difficult. Analytical techniques such as x-ray fluorescence (XRF) are useful for solid samples but are limited to total element measurements (total sulfur vs. sulfate, total phosphorus vs. phosphate). Another technique, $\mathrm{x}$-ray diffraction (XRD), is useful for the identification of compounds present but only provides qualitative information such as the determination of crystal structures. For this report, the primary sludge anion data is based on a water leach which represents the sum of the anions in the interstitial liquid and the water soluble anions from the solids. For these measurements the sludge samples were prepared by adding approximately 1 gram of sludge to $10 \mathrm{~mL}$ of water, mixing for several minutes at room temperature on a vortex mixer, and separating the solids. The resulting solution was analyzed by ion chromatography and the anion concentration was normalized back to the wet weight of the sludge.

Additional sample preparations were performed to obtain estimates for the total anion content, which included microwave digestion for total phosphorus as phosphate and total sulfur as sulfate. The total halide content requires a caustic peroxide fusion followed by analysis by ion chromatography. As stated before the total nitrate and nitrite are taken from the analysis of a water wash.

\subsubsection{Microwave Digestion for the Analysis of Phosphate and Sulfate}

Microwave digestion of the C-1 and C-2 sludges were done following SW846 method 3051 protocol. Approximately 0.5 grams of the raw sludges were weighed into microwave vessels into which $10 \mathrm{~mL}$ of ultra pure nitric acid was added. Once there was no more off-gas observed the vessels were sealed and placed into the oven. After a "soft" oxidation step at 250 watts to slowly breakdown any volatile components of the sludges the temperature program of method 3051 was followed (slowly raised to 175 degrees centigrade in 5.5 minutes and held at temperature for 4.5 minutes). Once the vessels cooled they were opened and the digested samples were rinsed into flasks and diluted to $50 \mathrm{~mL}$ using type II water. The microwave preparations were analyzed by ion chromatography using at least a 50X dilution of the preparations to ensure that the analytical columns capacity was not exceeded by the high nitrate content in the preparations. The following IC conditions were used, Analytical column: Dionex IonPac AS11 (column used vs AS14 for the 
analysis of sulfate and phosphate because of the additional separation of these peaks from the large nitrate peak in the microwave preparations) The eluant used was a sodium hydroxide gradient starting at $0.5 \mathrm{mM}$ and gradually increasing to $35 \mathrm{mM}$.

\subsubsection{Caustic Fusion Method}

Hydroxide fusion preparations of the $\mathrm{C}-1$ and $\mathrm{C}-2$ sludges were done using the following protocol. Approximately $0.25 \mathrm{~g}$ of the raw sludges were weighed into passivated nickel crucibles. One and one half grams of reagent grade sodium peroxide and one gram of ultra pure sodium hydroxide were added to each sample. Once no more reaction was observed the crucibles were covered and placed into a muffle furnace heated to 600 degrees centigrade for 15 minutes. At the end of the heating period the crucibles were removed from the oven and allowed to cool slightly (1-2 min.). While still warm the fused solids were rinsed into flasks using type II water and diluted to $50 \mathrm{~mL}$.

Prior to analysis by ion chromatography the fusion preparations were passed through a cation exchange column to remove the excess sodium in the preparations. Excess sodium in the samples will cause interference of the early eluting analytes such as fluoride and chloride. The cation columns were converted to an acid form using $1 \underline{\mathrm{M}}$ nitric acid then washed using type II water prior to sample loading. The following IC conditions were used, analytical column was a Dionex IonPac AS14 which was used for the fusion preparations and water preparations because of its fast run time and good resolution of the bromide and nitrate peaks. The eluant was $3.5 \mathrm{mM}$ sodium carbonate/ $1 \mathrm{mM}$ sodium bicarbonate.

It is important to note that the microwave dissolution and the caustic fusion preparation method for the sludge samples measures total concentrations of each element reported. An example would be sulfate analysis. A water leach of the sludge will yield a sulfate concentration due to water soluble compounds containing sulfate while the other preparation methods of the sludge yield a sulfur concentration due not only to the compounds containing sulfates (both water soluble and insoluble) but any compound containing sulfur. In other words these preparations yield a total sulfur concentration rather than a total sulfate concentration. In theory, the same principle applies to any anion determined using the fusion or total dissolution preparation methods. 
The final anion measurement technique was ion chromatography, no matter which sample preparation method was used. For simple water samples, without complex chemical matrix problems, the empirical analytical error for ion chromatography measurements ranges from 4-6\% for concentrations above 10 times the detection limits to $20-40 \%$ near the detection limit. The measurement of anions present at concentrations much lower $(<1 / 25)$ than other anionic species present may increase the overall error of the measurement.

\subsection{Radiochemical Analysis}

The only standard radiochemical methods useful for radioactive waste characterization are EPA Method 600/900.0, Gross Alpha and Beta Radioactivity in Drinking Water, and EPA Method 600/901.1: Gamma Emitting Radionuclides in Drinking Water. The EPA Method 600/905.0, Radioactive Strontium in Drinking Water, gave poor performance with the chemical matrix found in ORNL LLLW supernatant and sludge samples. The EPA method for gross alpha/beta measurements uses gas-flow proportional counting. In general, this counting technique requires drying a sample at elevated temperatures onto a metal (usually stainless steel) plate, which resulted in the loss of cesium chloride and other volatile radionuclides such as ${ }^{3} \mathrm{H},{ }^{14} \mathrm{C},{ }^{99} \mathrm{Tc},{ }^{106} \mathrm{Ru}$, and ${ }^{129} \mathrm{I}$, which resulted in poor gross beta measurements for the ORNL waste samples. To avoid this problem, all gross beta measurements reported are based on measurements by liquid scintillation counting. Other than the gamma spectroscopy measurements, all of the radionuclide measurements were done with in-house procedures. The method detection limits for radiochemical measurements are dependent on both sample matrix and count time and are not listed here. In general, the radiochemical measurements used count times to yield at least $1 \%(10,000$ counts) counting statistics. The expected errors for the radiochemical data range from $\pm 5-10 \%$ for gross alpha/beta and gamma emitter measurements to $\pm 10-20 \%$ for radionuclides that require chemical separations before counting (i.e. ${ }^{90} \mathrm{Sr},{ }^{129} \mathrm{I},{ }^{237} \mathrm{~Np}$, etc.).

The long-lived fission products are typically more difficult and expensive to measure than shortlived fission products. Many of these long-lived radionuclides are either pure beta emitters or have weak, low energy, and/or low yield gamma-rays which are not very useful for accurate analytical 
measurements. In general, good radiochemical data requires that each of these isotopes be chemically separated from all other radioactivity prior to measurement. These chemical separations and measurements are currently being done routinely for ${ }^{99} \mathrm{Tc}$ and ${ }^{129} \mathrm{I}$ because both can exist as anionic species $\left(\mathrm{TcO}_{4}^{-}, \mathrm{I}^{-}\right.$, and $\left.\mathrm{IO}_{3}^{-}\right)$in the waste, and these anions would be highly mobile in the environment. The ${ }^{99} \mathrm{Tc}$ is currently measured by ICP-MS without prior chemical separation and is much more sensitive than counting techniques. The ${ }^{129} \mathrm{I}$ is first extracted into carbon tetrachloride as iodine $\left(\mathrm{I}_{2}\right)$, then reduced to iodide $(\mathrm{I})$, back-extracted into an aqueous matrix, and loaded onto an anion exchange resin. The ${ }^{129} \mathrm{I}$ is then determined by neutron activation analysis. Typically the level of ${ }^{99} \mathrm{Tc}$ and ${ }^{129} \mathrm{I}$ in the waste is lower than expected from the fission yields, and one possible explanation is that both isotopes may have been volatilized as $\mathrm{HTcO}_{4}, \mathrm{HI}$, and $\mathrm{I}_{2}$ when exposed to either acid and/or heat in the past.

The long-lived fission products are a very small fraction of the overall activity present in the waste, and there has been little interest in the measurement of these radionuclides in the past. The determination of these isotopes are less routine and are frequently more expensive methods to perform. The judgement of most waste characterization teams has been that the measurement of these radionuclides, with the exception of ${ }^{99} \mathrm{Tc}$, would be interesting but there is insufficient risk to justify the analytical cost.

\subsection{Criticality Controls}

Historically the ORNL waste acceptance criteria (WAC) for liquid-low level waste has required that the fissile isotopes of uranium and plutonium be isotopically diluted with ${ }^{238} \mathrm{U}$ and ${ }^{232} \mathrm{Th}$, respectively. The administrative controls in place when most of the waste was generated required that the ratio of the ${ }^{238} \mathrm{U}$ mass divided by the fissile equivalent mass (FEM) for uranium be greater than 100 (see eq. 1). A similar administrative control was also in place for diluting ${ }^{239} \mathrm{Pu}$ with ${ }^{232} \mathrm{Th}$ (see eq. 2). More recently (within the last year) these requirements for the dilution ratios have been increased to more conservative values (see eq. 3 and eq. 4) for newly generated waste. The ${ }^{235} \mathrm{U}$ FEM is a useful scale for criticality calculations that normalizes the fission probability for each fissile isotope to ${ }^{235} \mathrm{U}$. These FEM factors, designated as $f_{35}$ for ${ }^{235} \mathrm{U}$ mass factors, are discussed and listed in the Appendix A, Table 1 of ORNL Procedure NCS-1.0, Nuclear Criticality Safety Program. 
The major fissile isotopes of concern in the ORNL waste tanks are ${ }^{233} \mathrm{U},{ }^{235} \mathrm{U}$, and ${ }^{239} \mathrm{Pu}$. The fissile isotope ${ }^{241} \mathrm{Pu}$ is also present in the waste, but the mass is usually several orders of magnitude lower and below a level that would influence the isotopic dilution ratio for plutonium. Other fissile isotopes present in the ORNL waste include isotopes of neptunium, americium, and curium, but the actual mass present in the waste has been too low for major concern, and the low concentration would make it difficult and expensive to measure by mass spectrometry.

The data presented in this report for isotopic dilution ratios (also referred to as denature ratios) reflect both the past and current ORNL standard practices for disposal of fissile isotopes of uranium and plutonium. The administrative controls which were in effect when most of the waste was generated, required that the ${ }^{233} \mathrm{U}$ and ${ }^{235} \mathrm{U}$ be diluted with depleted uranium such that the following condition was true,

$$
\frac{(238)}{(1.35)\left({ }^{233} U\right)+\left({ }^{235} U\right)} \geq 100
$$

Because thorium chemistry is more similar to plutonium chemistry, the past administrative controls required that the ${ }^{239} \mathrm{Pu}$ be diluted with ${ }^{232} \mathrm{Th}$ as follows,

$$
\frac{\left({ }^{232} T h\right)}{\left({ }^{239} P u\right)} \geq 100
$$

All calculations dealing with isotopic dilution for criticality safety are based on isotope mass ratios and must not be confused with activity ratios. For any data discussed in this report that uses ${ }^{232} \mathrm{Th}$ relative to isotopic mass ratios, the total thorium concentration and the ${ }^{232} \mathrm{Th}$ concentration are the same value. 
The new requirements for administrative criticality control are more conservative and require that the following conditions be satisfied for uranium,

$$
\begin{aligned}
& \frac{\left({ }^{238} U\right)-200\left({ }^{233} U\right)}{\left({ }^{235} U\right)} \geq 110 \\
& \frac{\left({ }^{238} U\right)-100\left({ }^{235} U\right)}{\left({ }^{233} U\right)} \geq 200
\end{aligned}
$$

The new administrative controls also change requirements for plutonium by increasing the ratio of thorium to plutonium, as given in eq. 2 , from a dilution ratio of 100 to a ratio of 200 .

\subsection{Organic Analysis}

The organic sample preparation and analysis methods were based on SW-846 methods which had been adapted for radioactive samples. The performance of these methods had been demonstrated according to the Transuranic Waste Characterization Program (TWCP) Quality Assurance Program Plan (QAPP) ${ }^{15}$ requirements. The amounts of sample extracted and analyzed for this project were limited to ensure contamination control and good ALARA practices. In general, it was not necessary to reduce the sensitivities of the volatile organic compound analysis (VOA), the non-halogenated volatile organic compound analysis (NHVOA), the semivolatile organic compound analysis (SVOA), or the polychlorinated biphenyls (PCB) analysis to meet sampling handling requirements due to the radioactivity.

\subsubsection{Non-halogenated Volatile Organic Analysis (NHVOA)}

The NHVOA measurements were done by SW-846 Method 8015A, Nonhalogenated Volatile Organics by Gas Chromatography. Approximately two grams of sludge was extracted by shaking with $10 \mathrm{~mL}$ of water. This extraction was increased by a factor of five from the method used in the TWCP, and therefore the method detection limits (MDL) were a factor of five higher. A volume 
of $0.001 \mathrm{~mL}$ of the extract was injected onto each of two gas chromatography columns, and the organic compounds were detected by flame ionization and quantified using the method of external standards. A surrogate standard was added to all samples and quality control samples. The latter included a laboratory blank, matrix spike (MS) and spike duplicate (MSD) samples, and a laboratory control sample (LCS).

\subsubsection{Volatile Organic Analysis (VOA)}

The VOA measurements were done by SW-846 Method 8260A, Volatile Organic Compounds by Gas Chromatography/Mass Spectrometry (GC/MS): Capillary Column Technique. For sludge samples approximately two grams of sludge was extracted by shaking with $10 \mathrm{~mL}$ of methanol. A $0.05 \mathrm{~mL}$ aliquot of the extract was added to $5 \mathrm{~mL}$ of water and was subjected to purge and trap gas chromatography-mass spectrometry (GC-MS). Quantitation was by the method of internal standards. Surrogate standards were added to all samples and quality control samples. The latter included a laboratory blank, MS and MSD, and a LCS.

\subsubsection{Semivolatile Organic Analysis (SVOA)}

The SVOA measurements included SW-846 Method 3550A, Ultrasonic Extraction, for sample preparation, and SW-846 Method 8270B, Semivolatile Organic Compounds by Gas Chromatography / Mass Spectrometry (GC/MS): Capillary Column Technique, for sample analysis. For sludge samples, two grams of sludge were mixed with sodium sulfate until a free-flowing matrix was obtained, and the mixture was extracted with $100 \mathrm{~mL}$ of methylene chloride using an ultrasonic bath. The methylene chloride was concentrated to $1 \mathrm{~mL}$, and the extract was analyzed by GC-MS using the method of internal standards. Surrogate standards were added to all samples and quality control samples. The latter included a laboratory blank, MS and MSD, and a LCS.

\subsubsection{Polychlorinated Biphenyls (PCB)}

The PCB measurements included SW-846 Method 3550A, Ultrasonic Extraction and Method 3665, Sulfuric Acid/Permanganate Cleanup, for sample preparation, and Method 8081, Organochlorine Pesticides and PCBs as Aroclors by Gas Chromatography: Capillary Column Technique, for sample analysis. A fraction of the SVOA methylene chloride extract was used for the PCB sample 
preparation. The extract was concentrated and solvent-exchanged into hexane, washed with sulfuric acid until the acid washes were colorless and did not contain precipitates, washed with water to remove excess acid, combined with a hexane back-extract of the acid washes, and then were concentrated to $1 \mathrm{~mL}$. Analysis was conducted on a dual capillary column GC equipped with dual electron capture detectors using the method of external standards. A surrogate standard was added to all samples and quality control samples. The latter included a laboratory blank, MS and MSD, and a LCS. 


\subsection{Quality Assurance}

Both the inorganic and organic chemical characterization of the $\mathrm{C} 1$ and $\mathrm{C} 2$ sludge samples followed the method requirements and Data Quality Objectives (DQO) of the TWCP QAPP. The RMAL implements the TWCP QAPP with a flow down RMAL Quality Assurance Project Plan (QAPjP) ${ }^{16}$ and implementation procedures. The list of metals determined was expanded from the TWCP requirements to meet ORNL needs. Although the organic target compounds were those listed in the TWCP QAPP, the full set of semivolatile and volatile organic compounds for the EPA Contract Laboratory Program Target Compound List (TCL) were reported as Tentatively Identified Compounds (TIC), if they were detected in the samples.

Quality assurance during the sampling activities was primarily addressed by the use of approved procedures for sampling of the sludge phase found in each waste tank. These procedures provide detailed instructions for the collection, labeling, and shipping of each sample. Chain-of-custody forms were used to track individual samples from their collection point to the analytical laboratory.

The RMAL also operates under a Radioactive Waste Characterization QA Plan ${ }^{17}$ which, in conjunction with the TWCP QAPjP, defines the basis for quality assurance and quality control used for the analysis of the waste tank samples. The QA plans discuss staff qualification requirements, laboratory participation in performance demonstration programs, quality control acceptance criteria for analytical methods, sample management, and most other laboratory operations. The set of QA plans implemented for RMAL waste characterization meet both the WIPP and the Nevada Test Site (NTS) QA requirements for inorganic, organic, and radiochemical measurements. 


\subsection{Summary of Inorganic and Radiochemical Analytical Results}

\subsection{Description of Sludge Samples}

The C1-east (971004-021) and C1-west (971014-012) sludge samples varied in color from a light and dark tan to a yellow green. Both of the $\mathrm{Cl}$ core samples had black particulates dispersed throughout the sludge matrix. As can be seen in Figures 1 neither of these core samples were very homogeneous. The C2-east (971004-022) and C2-west (971014-013) core samples are shown in

Figures 2 and 3, respectively. The C2-east sludge went from yellow in color near the bottom of the tank and gradually changed from tan to brown moving to the top of the sludge layer. The $\mathrm{C} 2$-west core sample varied from brown to black moving from the bottom of the tank to the top of the sludge layer, and a dark yellow layer was observed about three inches from the top of the sludge. The sludge in both the $\mathrm{C} 1$ and $\mathrm{C} 2$ tanks had a smooth "mud-like" consistency with a tendency to stick to the surface of the core sampling tools. 
Figure 1 Photographs of C1-East and Cl-West Core Samples

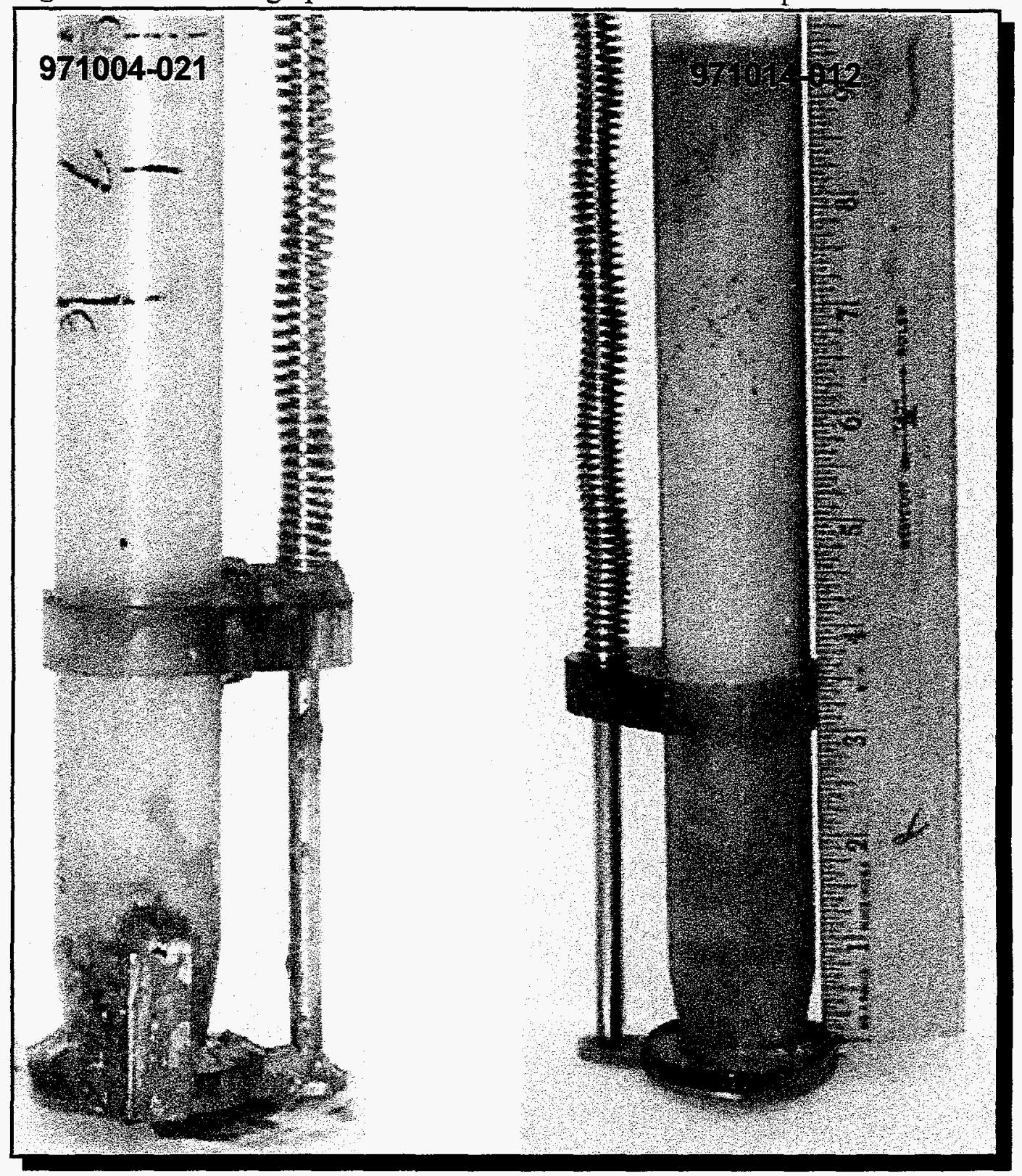


Figure 2 Photographs of C2-East Core Sample

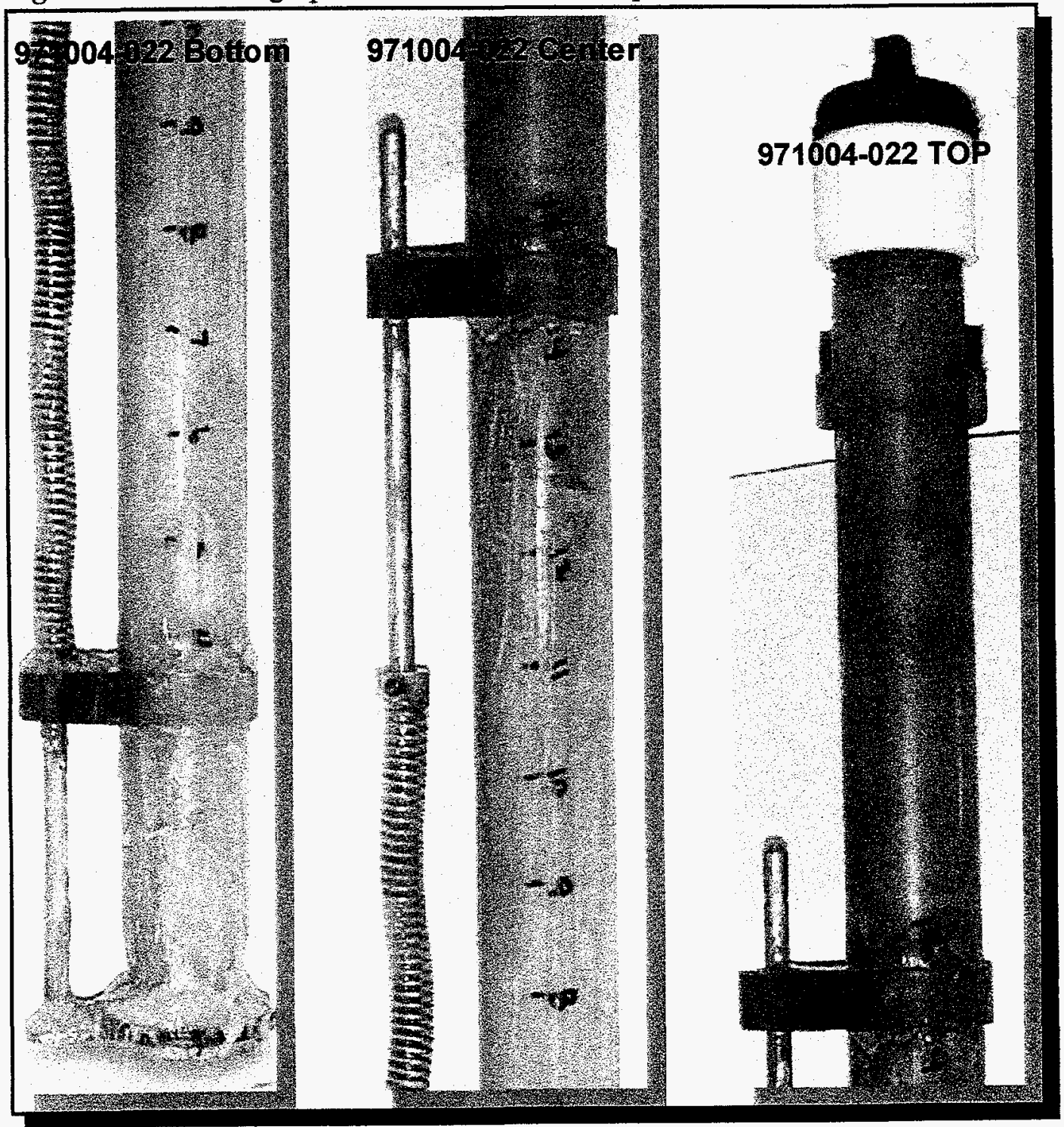


Figure 3 Photo of C2-West

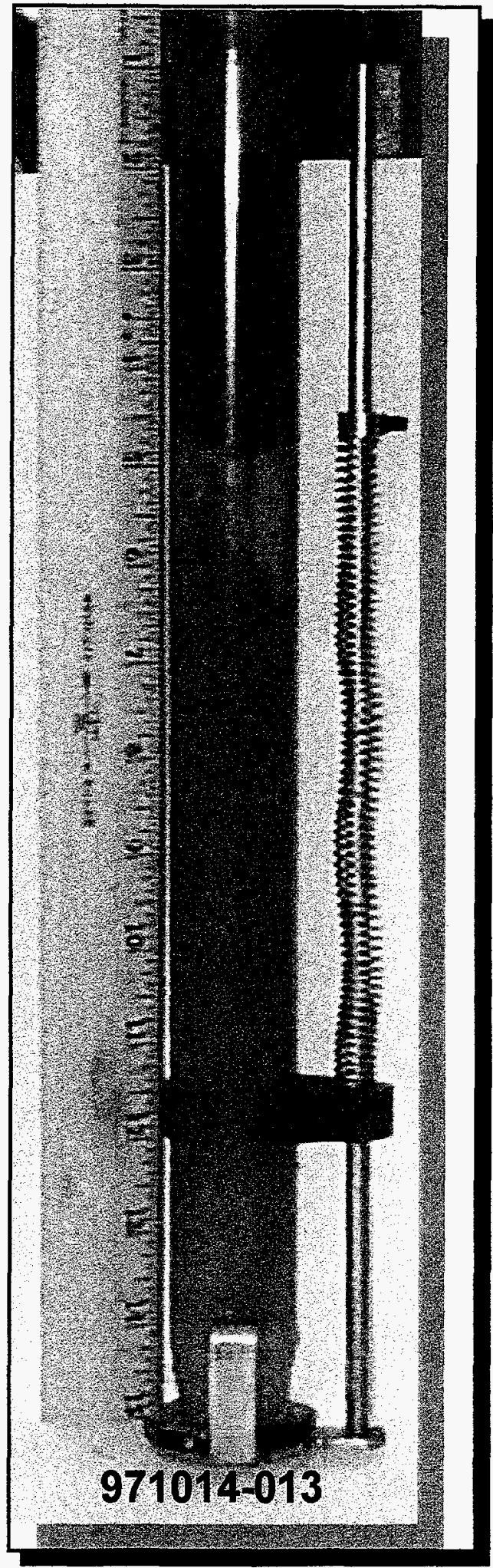




\subsection{Description of Data Tables}

A summary of the inorganic and radiochemical analytical results are presented in Table 3 for the $\mathrm{Cl}$ and $\mathrm{C} 2$ sludge samples. The table is arranged in a format to facilitate comparing data from different tanks and to group information into useful units. The analytical data presented in these tables are the consolidation of data from a single project which had a fixed set of analytical requirements. Any parameter reported with a dash ("-") indicates that the data was not measured for that sample.

The first section, "Physical properties and miscellaneous data", includes information that does not fit well into other table groups. The first parameters entered in a column include the RMAL request and sample numbers, which are laboratory filing codes used to track sample information. The next set of data includes information on the $\mathrm{pH}$, moisture or water content, and the solids content of the sample. The group is completed with data on the inorganic and organic carbon content. For most ORNL waste tank samples the inorganic carbon can be assumed to be all carbonate and bicarbonate. The Total Organic Carbon (TOC) provides an upper limit on the organic content in the tank waste and current methods include volatile organic compounds. Most of the liquid waste in the active system has been through an evaporator which removes the highly volatile organic compounds from the waste.

The next two sections include groups of metals; the "RCRA metals" are separated out for quick reference. The regulatory limit for the concentrations are listed in parentheses next to each RCRA metal. For the liquid samples, the RCRA regulatory limits are used directly, since the supernatant would be defined as the TCLP leachate in the determination of waste characteristics for hazardous waste. The RCRA metal sludge data represents total metal measurements, as defined by EPA. Exceeding the RCRA regulatory limits listed for the sludge samples only indicates that the waste has the potential to be classified as hazardous. The sludge waste should only be classified as RCRA waste if the final waste form fails the TCLP leaching test.

The remaining metals are grouped under "Process metals", which includes the common Group IA \& IIA metals along with elements that could effect chemical processing, criticality concerns, and 
stabilization techniques such as grouting or vitrification. For the sludge data, all the metals are reported on an "as received" (wet weight) basis.

The section "Semi-quantitative metals by ICP-MS" includes additional metals identified in a full mass range scan by inductively coupled plasma - mass spectrometry. This measurement helps ensure all major elements have been identified in the waste. Each element reported is quantified based upon a response factor from a curve generated from a few elements across the mass range, verses quantification based upon calibration with each element of interest. Therefore, these elemental concentrations are listed as estimates only.

The "Anions by ion chromatography" section include anions reported for the sludge samples based on a water wash of the sludge, as discussed in section 3.3. Along with the inorganic anions, several water soluble organic acids are reported, which includes compounds classified as complexing agents such as citrate and oxalate.

The "Beta/gamma emitters" section summarizes the radionuclides that emit gamma-rays and beta particles. This section includes the gross beta activity, radionuclides identified by gamma spectrometry, and several "pure" beta emitters of interest. Many of the "pure" beta emitters $\left({ }^{90} \mathrm{Sr}\right)$ require radiochemical separations prior to measurement by either liquid scintillation or gas-flow proportional counting. The ${ }^{99} \mathrm{Tc}$ was measured by ICP-MS without any prior chemical separation,.

The "Alpha emitters" section summarize the actinide elements in the waste. These section includes the gross alpha activity, an estimate of the activity for each alpha emitter identified in a gross alpha spectrum, and plutonium isotopes determined by alpha spectrometry after a radiochemical separation. The TRU activity as a mathematical sum of the Pu alpha and ${ }^{241} \mathrm{Am}$ is also listed in this section for quick reference. 
The remaining sections include "Uranium isotopes by TIMS", "Uranium isotopes by ICP-MS", and "Plutonium isotopes by ICP-MS". These sections summarize the uranium and plutonium data measured by thermal ionization mass spectrometry and for comparison to the uranium isotopes measured by ICP-MS. Also, included in these sections are the isotopic mass dilution or "denature" ratios for uranium and plutonium based on the requirements in place when the waste was generated (see section 3.5). The plutonium section for the sludge samples also includes the activity for each plutonium isotope, which was calculated from the mass spectrometry data. 
Table 3 Analytical Data for Sludge in C1 Tank

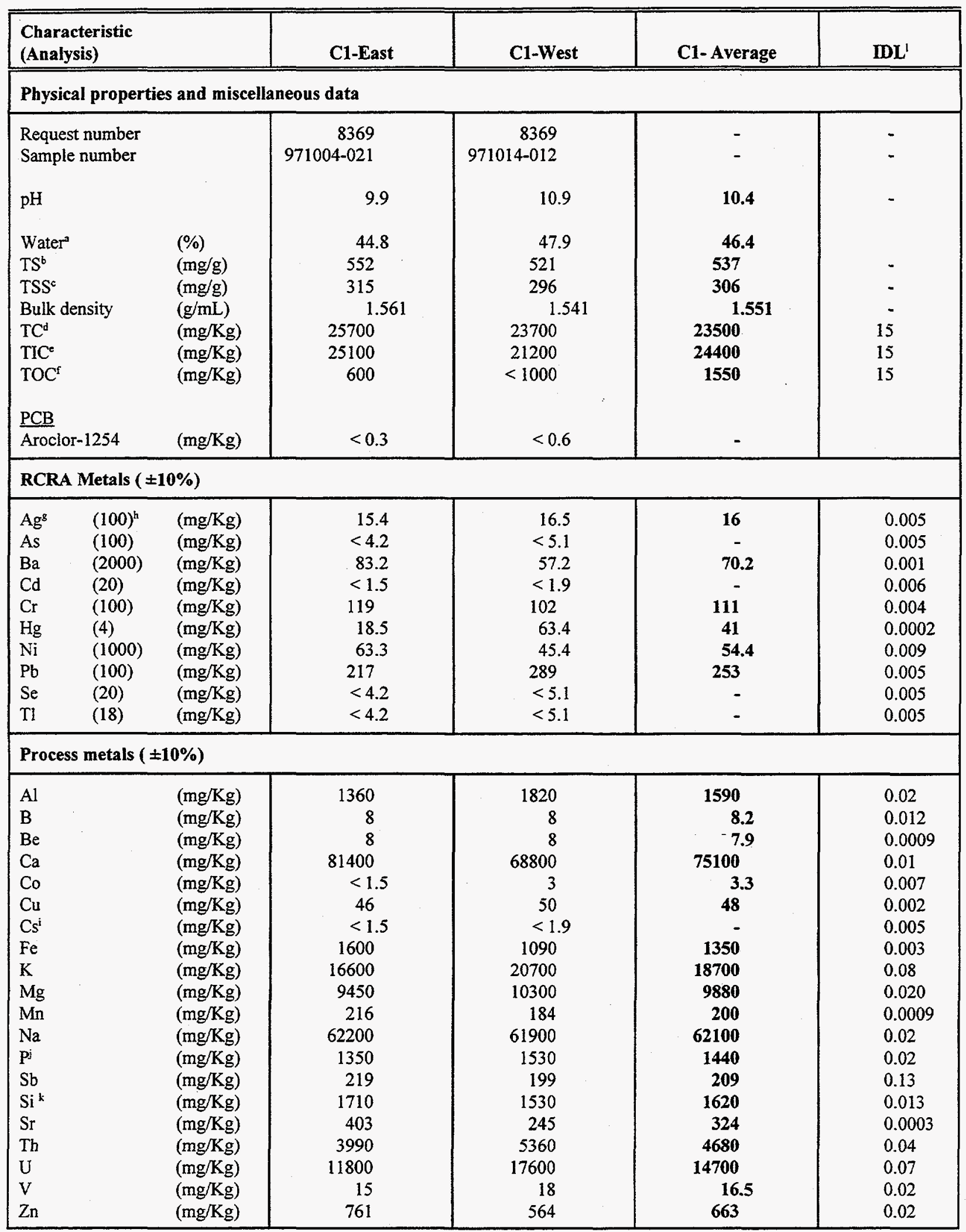




\begin{tabular}{|c|c|c|c|c|c|}
\hline $\begin{array}{l}\text { Characteristic } \\
\text { (Analysis) }\end{array}$ & & C1-East & C1-West & C1- Average & $\mathbf{I D L}^{1}$ \\
\hline \multicolumn{6}{|c|}{ Semi-quantitative metals by ICP-MS ( $\pm 30-50 \%$, * indicates data from water leach) } \\
\hline $\begin{array}{l}\mathrm{Bi} \text {, bismuth } \\
\mathrm{Ce} \text {, cerium } \\
\mathrm{Ga} \text {, gallium } \\
\mathrm{Gd} \text {, gadolinium } \\
\mathrm{Li} \text {, lithium } \\
\mathrm{Mo} \text {, molybdenum } \\
\mathrm{Sn} \text {, tin } \\
\mathrm{Te} \text {, Tellurium } \\
\mathrm{Ti} \text {, titanium } \\
\mathrm{W} \text {, tungsten } \\
\mathrm{Zr} \text {, zirconium }\end{array}$ & $\begin{array}{l}(\mathrm{mg} / \mathrm{Kg}) \\
(\mathrm{mg} / \mathrm{Kg}) \\
(\mathrm{mg} / \mathrm{Kg}) \\
(\mathrm{mg} / \mathrm{Kg}) \\
(\mathrm{mg} / \mathrm{Kg}) \\
(\mathrm{mg} / \mathrm{Kg}) \\
(\mathrm{mg} / \mathrm{Kg}) \\
(\mathrm{mg} / \mathrm{Kg}) \\
(\mathrm{mg} / \mathrm{Kg}) \\
(\mathrm{mg} / \mathrm{Kg}) \\
(\mathrm{mg} / \mathrm{Kg})\end{array}$ & $\begin{array}{l}13 \\
5.8 \\
5.4 \\
4.0 \\
2.2 \\
2.3 \\
9.0 \\
6.7 \\
7.4 \\
2.1 \\
3.3\end{array}$ & $\begin{array}{c}68 \\
5.7 \\
4.7 \\
4.8 \\
3.3 \\
2.3 \\
8.5 \\
14 \\
10 \\
<1.9 \\
5.4\end{array}$ & $\begin{array}{c}41 \\
5.8 \\
5.1 \\
4.4 \\
2.7 \\
2.3 \\
8.8 \\
10 \\
8.7 \\
- \\
4.4\end{array}$ & $\begin{array}{l}- \\
- \\
- \\
- \\
- \\
- \\
- \\
- \\
-\end{array}$ \\
\hline \multicolumn{6}{|c|}{ Anions by ion chromatography in water wash of sludge $( \pm 10 \%)$} \\
\hline $\begin{array}{l}\text { Inorganic } \\
\text { Bromide } \\
\text { Chloride } \\
\text { Chromate } \\
\text { Fluoride } \\
\text { Nitrate } \\
\text { Nitrite } \\
\text { Phosphate } \\
\text { Sulphate } \\
\text { Organic } \\
\text { Acetate } \\
\text { Citrate } \\
\text { Formate } \\
\text { Oxalate } \\
\text { Phthalate }\end{array}$ & $\begin{array}{l}(\mathrm{mg} / \mathrm{Kg}) \\
(\mathrm{mg} / \mathrm{Kg}) \\
(\mathrm{mg} / \mathrm{Kg}) \\
(\mathrm{mg} / \mathrm{Kg}) \\
(\mathrm{mg} / \mathrm{Kg}) \\
(\mathrm{mg} / \mathrm{Kg}) \\
(\mathrm{mg} / \mathrm{Kg}) \\
(\mathrm{mg} / \mathrm{Kg}) \\
\\
(\mathrm{mg} / \mathrm{Kg}) \\
(\mathrm{mg} / \mathrm{Kg}) \\
(\mathrm{mg} / \mathrm{Kg}) \\
(\mathrm{mg} / \mathrm{Kg}) \\
(\mathrm{mg} / \mathrm{Kg})\end{array}$ & $\begin{array}{c}<48 \\
2810 \\
<5 \\
<48 \\
195000 \\
1090 \\
<10 \\
1230 \\
179 \\
<5 \\
87.6 \\
<5 \\
<5\end{array}$ & $\begin{array}{c}<48 \\
3140 \\
<4 \\
53.7 \\
161000 \\
1860 \\
<9 \\
1800 \\
\\
1820 \\
<4 \\
99.4 \\
870 \\
<4\end{array}$ & $\begin{array}{r}- \\
2980 \\
- \\
53.7 \\
178000 \\
1475 \\
- \\
1520 \\
1000 \\
- \\
93.5 \\
870 \\
-\end{array}$ & $\begin{array}{l}0.05 \\
0.05 \\
0.01 \\
0.05 \\
0.10 \\
0.10 \\
0.20 \\
0.10 \\
- \\
- \\
- \\
- \\
-\end{array}$ \\
\hline \multicolumn{6}{|c|}{ Beta/gamma emitters $( \pm 10 \%)$} \\
\hline $\begin{array}{l}\frac{\text { Gross beta }}{{ }^{63} \mathrm{Ni}} \\
{ }^{60} \mathrm{Co} \\
{ }^{90} \mathrm{Sr}{ }^{90} \mathrm{Y} \\
{ }^{99} \mathrm{Tc} \\
{ }^{129} \mathrm{I} \\
{ }^{134} \mathrm{Cs} \\
{ }^{137} \mathrm{Cs} \\
{ }^{152} \mathrm{Eu} \\
{ }^{154} \mathrm{Eu} \\
{ }^{155} \mathrm{Eu} \\
{ }^{227} \mathrm{Ac} \\
{ }^{241} \mathrm{Pu}\end{array}$ & $\begin{array}{l}(\mathrm{Bq} / \mathrm{g}) \\
(\mathrm{Bq} / \mathrm{g}) \\
(\mathrm{Bq} / \mathrm{g}) \\
(\mathrm{Bq} / \mathrm{g}) \\
(\mathrm{Bq} / \mathrm{g}) \\
(\mathrm{Bq} / \mathrm{g}) \\
(\mathrm{Bq} / \mathrm{g}) \\
(\mathrm{Bq} / \mathrm{g}) \\
(\mathrm{Bq} / \mathrm{g}) \\
(\mathrm{Bq} / \mathrm{g}) \\
(\mathrm{Bq} / \mathrm{g}) \\
(\mathrm{Bq} / \mathrm{g}) \\
(\mathrm{Bq} / \mathrm{g})\end{array}$ & $\begin{array}{r}4100000 \\
13000 \\
43000 \\
1200000 \\
<140 \\
- \\
7900 \\
460000 \\
540000 \\
240000 \\
39000 \\
- \\
15000\end{array}$ & $\begin{array}{r}3600000 \\
4400 \\
21000 \\
880000 \\
507 \\
- \\
19000 \\
700000 \\
520000 \\
150000 \\
38000 \\
- \\
15000\end{array}$ & $\begin{array}{r}3850000 \\
8700 \\
32000 \\
1000000 \\
507 \\
- \\
13500 \\
580000 \\
530000 \\
195000 \\
38500 \\
- \\
15000\end{array}$ & $\begin{array}{l}- \\
- \\
- \\
- \\
- \\
- \\
- \\
- \\
- \\
- \\
- \\
-\end{array}$ \\
\hline
\end{tabular}




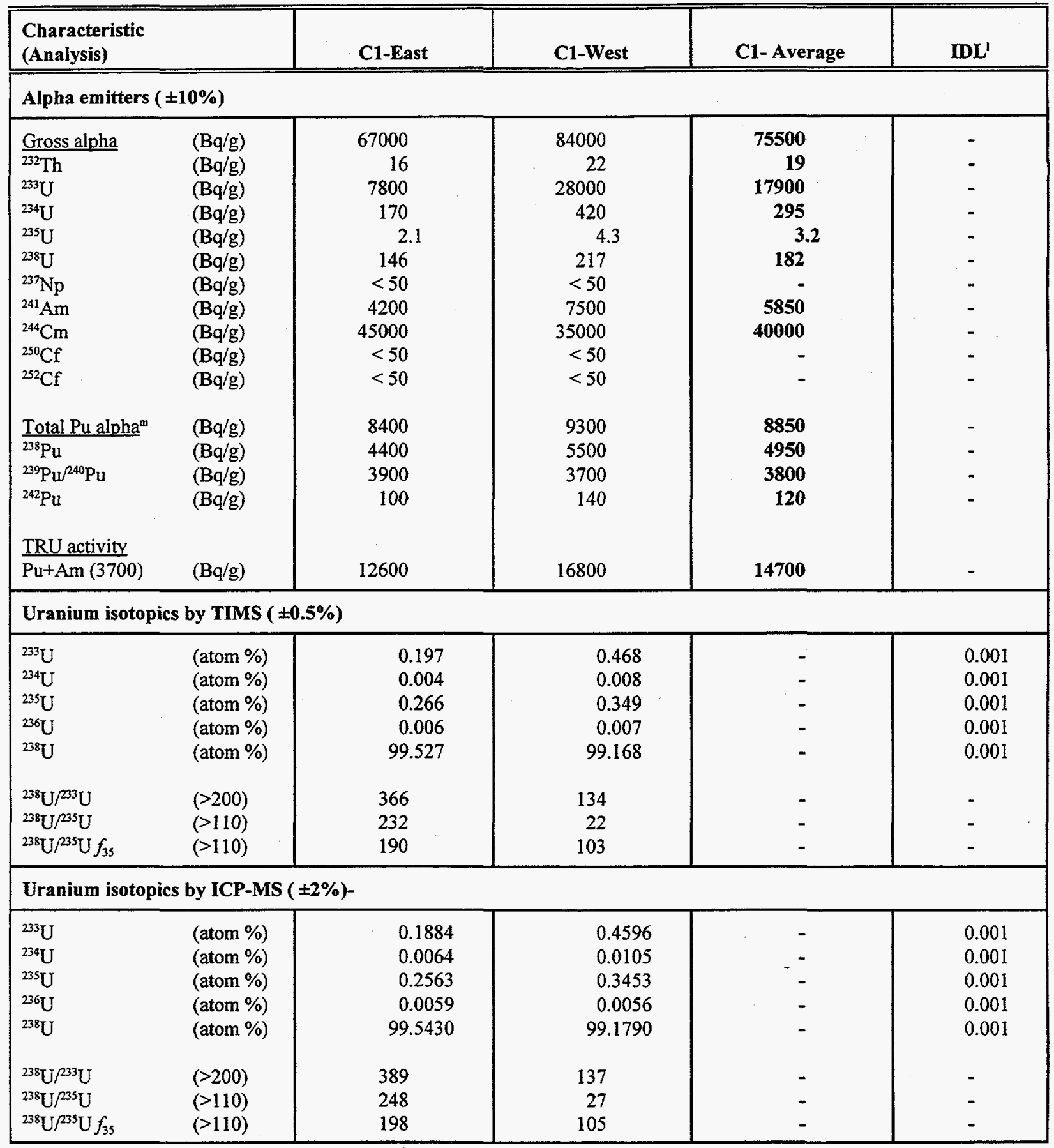




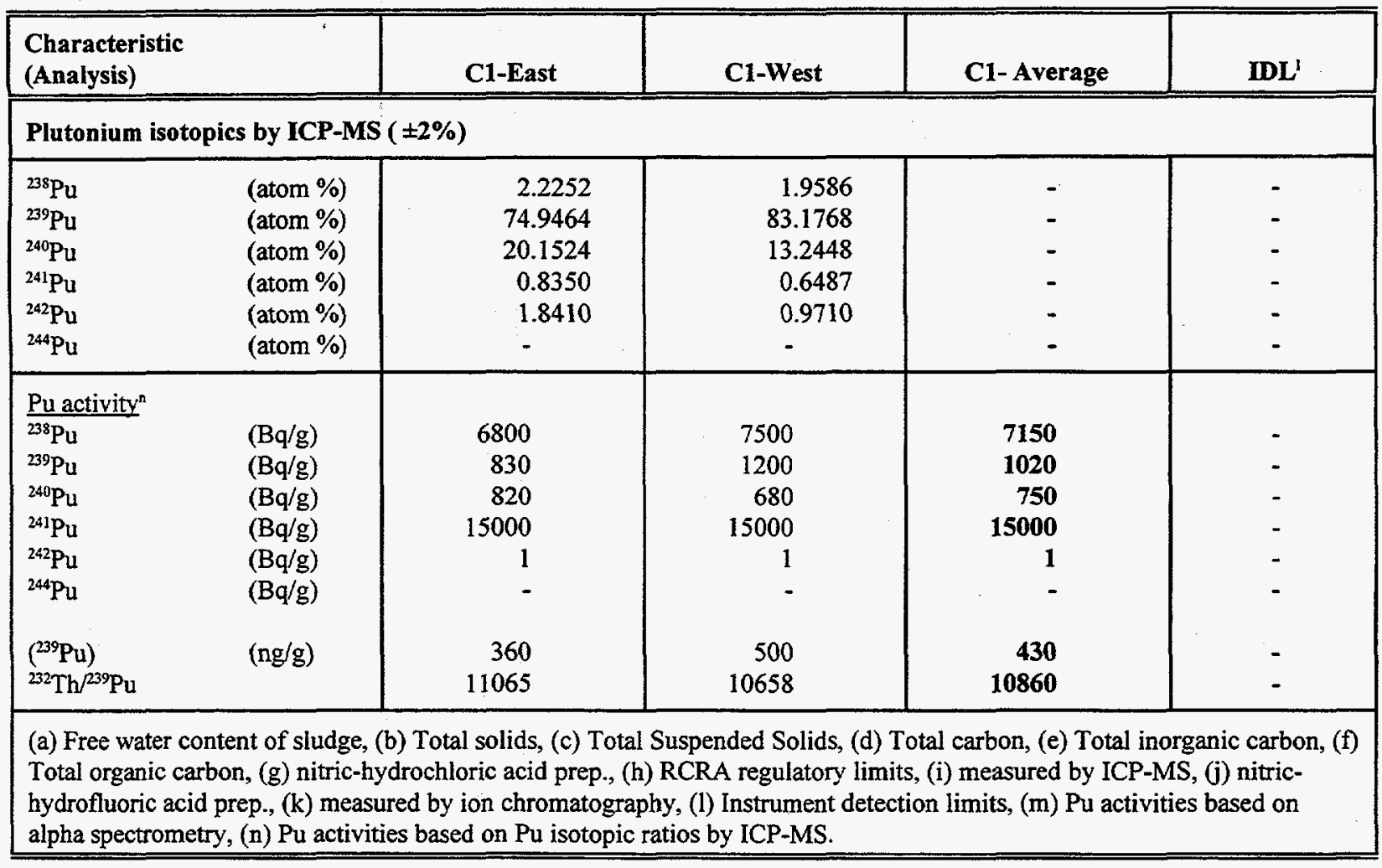


Table 4 Analytical Data for Sludge in C2 Tank

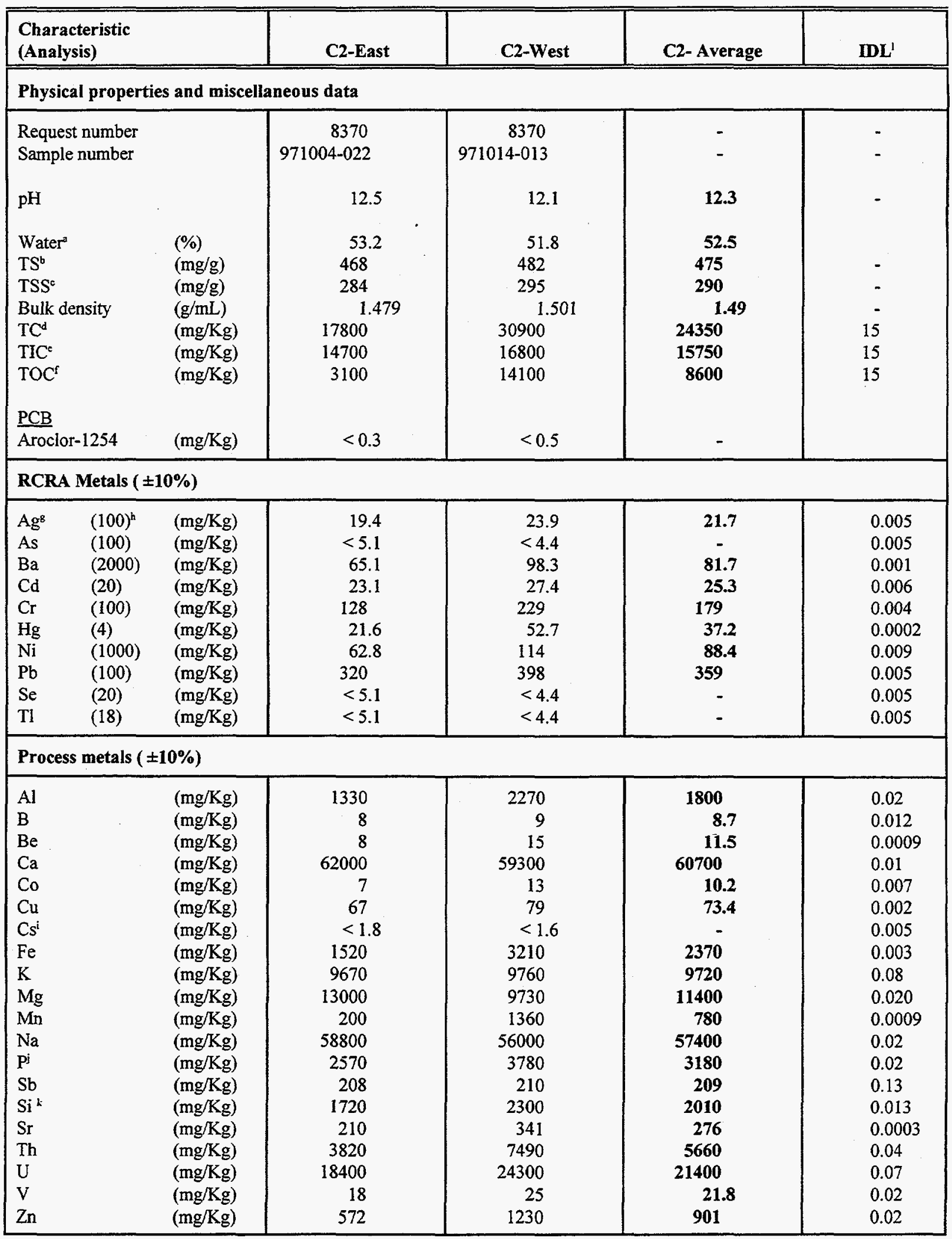




\begin{tabular}{|c|c|c|c|c|c|}
\hline $\begin{array}{l}\text { Characteristic } \\
\text { (Analysis) }\end{array}$ & & C2-East & C2-West & C2-Average & mL' \\
\hline \multicolumn{6}{|c|}{ Semi-quantitative metals by ICP-MS $\left( \pm 30-50 \%,{ }^{*}\right.$ indicates data from water leach) } \\
\hline $\begin{array}{l}\mathrm{Bi} \text {, bismuth } \\
\mathrm{Ce} \text {, cerium } \\
\mathrm{Ga} \text {, gallium } \\
\mathrm{Gd} \text {, gadolinium } \\
\mathrm{Li} \text {, lithium } \\
\mathrm{Mo} \text {, molybdenum } \\
\mathrm{Sn} \text {, tin } \\
\mathrm{Te} \text {, Tellurium } \\
\mathrm{Ti} \text {, titanium } \\
\mathrm{W} \text {, tungsten } \\
\mathrm{Zr} \text {, zirconium }\end{array}$ & $\begin{array}{l}(\mathrm{mg} / \mathrm{Kg}) \\
(\mathrm{mg} / \mathrm{Kg}) \\
(\mathrm{mg} / \mathrm{Kg}) \\
(\mathrm{mg} / \mathrm{Kg}) \\
(\mathrm{mg} / \mathrm{Kg}) \\
(\mathrm{mg} / \mathrm{Kg}) \\
(\mathrm{mg} / \mathrm{Kg}) \\
(\mathrm{mg} / \mathrm{Kg}) \\
(\mathrm{mg} / \mathrm{Kg}) \\
(\mathrm{mg} / \mathrm{Kg}) \\
(\mathrm{mg} / \mathrm{Kg})\end{array}$ & $\begin{array}{l}18 \\
12 \\
5.2 \\
7.8 \\
3.4 \\
3.5 \\
11 \\
8.7 \\
11 \\
2.3 \\
4.1\end{array}$ & $\begin{array}{l}23 \\
15 \\
8.2 \\
8.0 \\
4.0 \\
3.3 \\
24 \\
14 \\
23 \\
2.4 \\
8.2\end{array}$ & $\begin{array}{c}21 \\
14 \\
6.7 \\
7.9 \\
3.7 \\
3.4 \\
18 \\
11 \\
17 \\
2.4 \\
6.2\end{array}$ & $\begin{array}{l}- \\
- \\
- \\
- \\
- \\
- \\
- \\
-\end{array}$ \\
\hline \multicolumn{6}{|c|}{ Anions by ion chromatography in water wash of sludge $( \pm 10 \%)$} \\
\hline $\begin{array}{l}\text { Inorganic } \\
\text { Bromide } \\
\text { Chloride } \\
\text { Chromate } \\
\text { Fluoride } \\
\text { Nitrate } \\
\text { Nitrite } \\
\text { Phosphate } \\
\text { Sulphate } \\
\text { Organic } \\
\text { Acetate } \\
\text { Citrate } \\
\text { Formate } \\
\text { Oxalate } \\
\text { Phthalate }\end{array}$ & $\begin{array}{l}(\mathrm{mg} / \mathrm{Kg}) \\
(\mathrm{mg} / \mathrm{Kg}) \\
(\mathrm{mg} / \mathrm{Kg}) \\
(\mathrm{mg} / \mathrm{Kg}) \\
(\mathrm{mg} / \mathrm{Kg}) \\
(\mathrm{mg} / \mathrm{Kg}) \\
(\mathrm{mg} / \mathrm{Kg}) \\
(\mathrm{mg} / \mathrm{Kg}) \\
\\
(\mathrm{mg} / \mathrm{Kg}) \\
(\mathrm{mg} / \mathrm{Kg}) \\
(\mathrm{mg} / \mathrm{Kg}) \\
(\mathrm{mg} / \mathrm{Kg}) \\
(\mathrm{mg} / \mathrm{Kg})\end{array}$ & $\begin{array}{c}<50 \\
4800 \\
<5 \\
<50 \\
134000 \\
3130 \\
15.8 \\
5540 \\
\\
983 \\
12.9 \\
170 \\
57.5 \\
10.4\end{array}$ & $\begin{array}{c}<48 \\
4440 \\
<5 \\
87.4 \\
124000 \\
3140 \\
<10 \\
5110 \\
1330 \\
53.6 \\
178 \\
959 \\
25.4\end{array}$ & $\begin{array}{c}-\dot{-} \\
4620 \\
- \\
87.4 \\
129000 \\
1730 \\
15.8 \\
5330 \\
\\
1160 \\
33.3 \\
174 \\
508 \\
17.9\end{array}$ & $\begin{array}{l}0.05 \\
0.05 \\
0.01 \\
0.05 \\
0.10 \\
0.10 \\
0.20 \\
0.10 \\
- \\
- \\
- \\
- \\
-\end{array}$ \\
\hline \multicolumn{6}{|c|}{ Beta/gamma emitters $( \pm 10 \%)$} \\
\hline $\begin{array}{l}\text { Gross beta } \\
{ }^{63} \mathrm{Ni} \\
{ }^{60} \mathrm{Co} \\
{ }^{90} \mathrm{Sr} /{ }^{90} \mathrm{Y} \\
{ }^{99} \mathrm{Tc} \\
{ }^{129} \mathrm{I} \\
{ }^{134} \mathrm{Cs} \\
{ }^{137} \mathrm{Cs} \\
{ }^{152} \mathrm{Eu} \\
{ }^{154} \mathrm{Eu} \\
{ }^{155} \mathrm{Eu} \\
{ }^{227} \mathrm{Ac} \\
{ }^{241} \mathrm{Pu}\end{array}$ & $\begin{array}{l}(\mathrm{Bq} / \mathrm{g}) \\
(\mathrm{Bq} / \mathrm{g}) \\
(\mathrm{Bq} / \mathrm{g}) \\
(\mathrm{Bq} / \mathrm{g}) \\
(\mathrm{Bq} / \mathrm{g}) \\
(\mathrm{Bq} / \mathrm{g}) \\
(\mathrm{Bq} / \mathrm{g}) \\
(\mathrm{Bq} / \mathrm{g}) \\
(\mathrm{Bq} / \mathrm{g}) \\
(\mathrm{Bq} / \mathrm{g}) \\
(\mathrm{Bq} / \mathrm{g}) \\
(\mathrm{Bq} / \mathrm{g}) \\
(\mathrm{Bq} / \mathrm{g})\end{array}$ & $\begin{array}{r}4800000 \\
8000 \\
47000 \\
890000 \\
<170 \\
- \\
35000 \\
920000 \\
1300000 \\
380000 \\
93000 \\
26000\end{array}$ & $\begin{array}{r}5800000 \\
21000 \\
64000 \\
1400000 \\
<150 \\
- \\
32000 \\
860000 \\
1200000 \\
480000 \\
98000 \\
- \\
57000\end{array}$ & $\begin{array}{r}5300000 \\
15000 \\
55500 \\
1145000 \\
- \\
- \\
33500 \\
890000 \\
1250000 \\
430000 \\
95500 \\
-\end{array}$ & $\begin{array}{l}- \\
- \\
- \\
- \\
- \\
- \\
- \\
- \\
- \\
-\end{array}$ \\
\hline
\end{tabular}




\begin{tabular}{|c|c|c|c|c|c|}
\hline $\begin{array}{l}\text { Characteristic } \\
\text { (Analysis) }\end{array}$ & & C2-East & C2-West & C2- Average & $\mathbf{I D L}^{\mathbf{3}}$ \\
\hline \multicolumn{6}{|c|}{ Alpha emitters ( $\pm 10 \%)$} \\
\hline Gross alpha & $(\mathrm{Bq} / \mathrm{g})$ & 88000 & 160000 & 124000 & - \\
\hline${ }^{232} \mathrm{Th}$ & $(\mathrm{Bq} / \mathrm{g})$ & 16 & 30 & 23 & - \\
\hline${ }^{233} \mathrm{U}$ & $(\mathrm{Bq} / \mathrm{g})$ & 7300 & 14000 & 10700 & - \\
\hline${ }^{234} \mathrm{U}$ & (Bq/g) & 250 & 280 & 265 & - \\
\hline & $(\mathrm{Bq} / \mathrm{g})$ & 4.1 & 6.4 & 5.3 & - \\
\hline${ }^{238} \mathrm{U}$ & $(\mathrm{Bq} / \mathrm{g})$ & 230 & 300 & 265 & - \\
\hline${ }^{237} \mathrm{~Np}$ & $(\mathrm{~Bq} / \mathrm{g})$ & $<50$ & $<50$ & - & - \\
\hline${ }^{241} \mathrm{Am}$ & $(\mathrm{Bq} / \mathrm{g})$ & 12100 & 12000 & 12100 & - \\
\hline${ }^{244} \mathrm{Cm}$ & $(\mathrm{Bq} / \mathrm{g})$ & 53000 & 110000 & 81500 & - \\
\hline${ }^{250} \mathrm{Cf}$ & $(\mathrm{Bq} / \mathrm{g})$ & $<50$ & $<50$ & - & - \\
\hline${ }^{252} \mathrm{Cf}$ & $(\mathrm{Bq} / \mathrm{g})$ & $<50$ & $<50$ & - & - \\
\hline Total Pu alpha & $(\mathrm{Bq} / \mathrm{g})$ & 14000 & 22000 & 18000 & - \\
\hline${ }^{238} \mathrm{Pu}$ & $(\mathrm{Bq} / \mathrm{g})$ & 7900 & 14000 & 11000 & - \\
\hline${ }^{239} \mathrm{Pu} /{ }^{240} \mathrm{Pu}$ & $(\mathrm{Bq} / \mathrm{g})$ & 5900 & 7700 & 6800 & - \\
\hline${ }^{242} \mathrm{Pu}$ & $(\mathrm{Bq} / \mathrm{g})$ & 150 & 77 & 113 & - \\
\hline \multicolumn{6}{|l|}{ TRU activity } \\
\hline $\mathrm{Pu}+\mathrm{Am}(3700)$ & $(\mathrm{Bq} / \mathrm{g})$ & 26100 & 34000 & 30100 & - \\
\hline \multicolumn{6}{|c|}{ Uranium isotopics by TIMS ( $\pm 0.5 \%)$} \\
\hline${ }^{233} \mathrm{U}$ & (atom \%) & 0.101 & 0.175 & - & 0.001 \\
\hline${ }^{234} \mathrm{U}$ & (atom \%) & 0.003 & 0.005 & - & 0.001 \\
\hline${ }^{235} \mathrm{U}$ & (atom \%) & 0.305 & 0.380 & - & 0.001 \\
\hline${ }^{236} \mathrm{U}$ & (atom \%) & 0.010 & 0.006 & - & 0.001 \\
\hline${ }^{238} \mathrm{U}$ & (atom \%) & 99.580 & 99.434 & - & 0.001 \\
\hline${ }^{238} \mathrm{U} /{ }^{233} \mathrm{U}$ & $(>200)$ & 672 & 340 & - & . \\
\hline${ }^{238} \mathrm{U}^{235} \mathrm{U}$ & $(>110)$ & 265 & 174 & - & - \\
\hline${ }^{238} \mathrm{U} /^{235} \mathrm{U} f_{35}$ & $(>110)$ & 229 & 164 & - & - \\
\hline \multicolumn{6}{|c|}{ Uranium isotopics by ICP-MS ( $\pm 2 \%$ ) } \\
\hline${ }^{233} \mathrm{U}$ & (atom \%) & 0.1139 & 0.1682 & - & 0.001 \\
\hline${ }^{234} \mathrm{U}$ & (atom \%) & 0.0060 & 0.0050 & $=$ & 0.001 \\
\hline${ }^{235} \mathrm{U}$ & (atom \%) & 0.3149 & 0.3764 & - & 0.001 \\
\hline${ }^{236} \mathrm{U}$ & (atom \%) & 0.0079 & 0.0048 & - & 0.001 \\
\hline${ }^{238} \mathrm{U}$ & (atom \%) & 99.5573 & 99.4456 & - & 0.001 \\
\hline${ }^{238} U \rho^{233} U$ & $(>200)$ & 586 & 356 & - & - \\
\hline${ }^{238} \mathrm{U}^{235} \mathrm{U}$ & $(>110)$ & 248 & 179 & - & - \\
\hline${ }^{238} \mathrm{U}{ }^{235} \mathrm{U} f_{35}$ & $(>110)$ & 216 & 167 & - & - \\
\hline
\end{tabular}




\begin{tabular}{|c|c|c|c|c|c|}
\hline $\begin{array}{l}\text { Characteristic } \\
\text { (Analysis) }\end{array}$ & & C2-East & C2-West & C2- Average & $\mathbf{D L}^{1}$ \\
\hline \multicolumn{6}{|c|}{ Plutonium isotopics by TIMS ( $\pm 1 \%$ ) } \\
\hline $\begin{array}{l}{ }^{238} \mathrm{Pu} \\
{ }^{239} \mathrm{Pu} \\
{ }^{240} \mathrm{Pu} \\
{ }^{241} \mathrm{Pu} \\
{ }^{242} \mathrm{Pu} \\
{ }^{444} \mathrm{Pu}\end{array}$ & $\begin{array}{l}\text { (atom \%) } \\
\text { (atom \%) } \\
\text { (atom\%) } \\
\text { (atom \%) } \\
\text { (atom\%) } \\
\text { (atom \%) }\end{array}$ & $\begin{array}{r}1.9350 \\
78.5289 \\
17.5362 \\
0.7408 \\
1.2590 \\
-\end{array}$ & $\begin{array}{r}1.0350 \\
77.2019 \\
19.2823 \\
0.6639 \\
1.8169 \\
-\end{array}$ & $\begin{array}{l}- \\
- \\
- \\
- \\
- \\
-\end{array}$ & $\begin{array}{l}- \\
- \\
- \\
- \\
-\end{array}$ \\
\hline $\begin{array}{l}\frac{\mathrm{Pu} \text { activity }}{{ }^{\mathrm{n}}} \\
{ }^{238} \mathrm{Pu} \\
{ }^{230} \mathrm{Pu} \\
{ }^{244} \mathrm{Pu} \\
{ }^{242} \mathrm{Pu} \\
{ }^{244} \mathrm{Pu} \\
\left.{ }^{(239} \mathrm{Pu}\right) \\
{ }^{232} \mathrm{Th} /{ }^{239} \mathrm{Pu}\end{array}$ & $\begin{array}{l}(\mathrm{Bq} / \mathrm{g}) \\
(\mathrm{Bq} / \mathrm{g}) \\
(\mathrm{Bq} / \mathrm{g}) \\
(\mathrm{Bq} / \mathrm{g}) \\
(\mathrm{Bq} / \mathrm{g}) \\
(\mathrm{Bq} / \mathrm{g}) \\
\\
(\mathrm{ng} / \mathrm{g})\end{array}$ & $\begin{array}{r}11000 \\
1600 \\
1300 \\
25000 \\
2 \\
- \\
710 \\
5382\end{array}$ & $\begin{array}{r}14000 \\
3900 \\
3600 \\
57000 \\
6 \\
- \\
1700 \\
4379\end{array}$ & $\begin{array}{r}12500 \\
2750 \\
2450 \\
41500 \\
4 \\
- \\
1200 \\
4880\end{array}$ & $\begin{array}{l}- \\
- \\
- \\
- \\
- \\
-\end{array}$ \\
\hline \multicolumn{6}{|c|}{$\begin{array}{l}\text { (a) Free water content of sludge, (b) Total solids, (c) Total Suspended Solids, (d) Total carbon, (e) Total inorganic carbon, } \\
\text { (f) Total organic carbon, (g) nitric-hydrochloric acid prep., (h) RCRA regulatory limits, (i) measured by ICP-MS, (j) nitric } \\
\text { hydrofluoric acid prep., (k) measured by ion chromatography, (l) Instrument detection limits, (m) Pu activities based on } \\
\text { alpha spectrometry, (n) Pu activities based on Pu isotopic ratios by ICP-MS. }\end{array}$} \\
\hline
\end{tabular}




\subsection{Discussion of $\mathrm{C} 1$ and $\mathrm{C2}$ Supernatant Characteristics}

Although the supernatant from $\mathrm{C} 1$ and $\mathrm{C} 2$ were not characterized for this project the information in this section is provided to help the reader understand the general chemistry in the waste tanks. The observations discussed in this section represent the general overall average that would be expected for the liquid phase in the active waste system at ORNL.

The Group IA elements, sodium and potassium, are very soluble in the supernatant at any $\mathrm{pH}$. In general, the concentration of Group IIA metals such as calcium and strontium will increase in the supernatant as the $\mathrm{pH}$ decreases. These Group IIA metals remain mostly soluble in the liquid phase at high $\mathrm{pH}$, but as carbon dioxide is absorbed into the supernatant from the air, both calcium and strontium form insoluble carbonate compounds. The general distribution of radioactivity in the waste tanks is a function of the $\mathrm{pH}$, where at higher $\mathrm{pH}$ the ${ }^{137} \mathrm{Cs}$ dominates the beta activity in the liquid phase and the ${ }^{90} \mathrm{Sr}{ }^{90} \mathrm{Y}$ is the predominate source of the beta activity in the sludge phase. At high $\mathrm{pH}$, the actinide elements are mostly insoluble which corresponds to most of the alpha activity being concentrated in the sludge phase.

The sludge layers in the ORNL waste tanks are typically high in several RCRA metals, including chromium, mercury, and lead. At high $\mathrm{pH}$ these RCRA metals are generally below the hazard limits in the supernatant, but as the $\mathrm{pH}$ decreases the concentration of these RCRA metals can increase to the point where the regulatory limits are exceeded in the liquid phase.

In general, the distribution of ${ }^{137} \mathrm{Cs}$ in the liquid waste is independent of $\mathrm{pH}$, and the ${ }^{90} \mathrm{Sr}$ activity is a function of both $\mathrm{pH}$ and carbonate concentration.

If the waste tank chemistry approaches the conditions where the $\mathrm{pH}$ is high and the carbonate concentration is low, it is possible for the ${ }^{90} \mathrm{Sr}$ to remain soluble and the ${ }^{90} \mathrm{Y}$ to precipitate as the hydroxide and disrupt the secular equilibrium. It is important to understand any conditions that could disrupt this equilibrium because some radiochemical screening techniques and the interpretation of beta dose assume that the ${ }^{90} \mathrm{Y}$ activity is equal to the ${ }^{90} \mathrm{Sr}$ activity. The separation of the strontium from the yttrium is frequently observed with ${ }^{90} \mathrm{Sr}$ contaminated water moving through soil. The soluble ${ }^{90} \mathrm{Sr}$ moves with the water and the ${ }^{90} \mathrm{Y}$ is absorbed to the soil by an ion 
exchange process. Past practices used clay based materials as a mobilizing agent for pumping sludge. Therefore, the sludge may have an ion exchange affinity for yttrium or other radionuclides, which could interfere with the expected behavior for some radionuclides or other chemical species.

In general, the beta/gamma emitters that would be in the $\mathrm{C} 1$ and $\mathrm{C} 2$ supernatant represent what would be expected for fission product waste that had been aged for 5-10 years. The ORNL liquid waste is normally stored at a caustic $\mathrm{pH}$ and the radioactive cesium dominates the activity for the liquid phase in most ORNL waste tanks.

The alpha activity is usually low in the supernatant, as would be expected with a caustic $\mathrm{pH}$ such as the $\mathrm{C} 1$ and $\mathrm{C} 2$ tanks. If the hydroxide concentration in the supernatant is less than about $0.1 \underline{\mathrm{M}}$, the uranium can form a complex with the carbonate present and become more soluble. Based on past experience, any alpha activity observed in the supernatant from $\mathrm{C} 1$ and $\mathrm{C} 2$ would most likely be due to suspended particles and the activity would be dominated by the ${ }^{244} \mathrm{Cm}$ present. The uranium contribution to the total alpha activity is typically minor relative to the ${ }^{244} \mathrm{Cm}$ activity present in ORNL waste.

\subsection{Discussion of C1 and C2 Sludge Characteristics}

Determination of the mass and charge balance for the sludge samples are more difficult than for the supernatant samples. Not only are there assumptions required about the chemical form and the oxidation state of the species present in the sludge, but many of the compounds in the sludge are mixed oxides which are not directly measured. Also, the sludge is actually a compressed slurry with a high water content. The interstitial liquid is in close contact with the sludge, and there are many ionic solubility equilibriums. The anion data for the sludge samples are based on the water soluble anions that would be available to a water wash. The water wash would not account for the insoluble hydroxides, carbonates, and mixed oxides present. The insoluble species do not contribute to the charge balance, and the cation charge is not used in the calculation, as indicated in Table 7. Most of the nitrate reported for the sludge is due to the interstitial liquid. Considering these limitations, the compounds listed in Table 5 were used to estimate the mass and charge balance. 
Table 5 Assumptions Used for Major Compounds in Sludge

\begin{tabular}{|c|c|c|c|}
\hline Cation & Chemical Form & $\begin{array}{c}\text { Cation } \\
\text { Charge Used }\end{array}$ & $\begin{array}{c}\text { Gravimetric } \\
\text { Factors }\end{array}$ \\
\hline \hline $\mathrm{Al}^{3+}$ & $\mathrm{Al}_{2} \mathrm{O}_{3}$ & 0 & 1.890 \\
$\mathrm{Ca}^{2+}$ & $\mathrm{CaCO}_{3}$ & 0 & 2.497 \\
$\mathrm{Fe}^{3+}$ & $\mathrm{Fe}_{2} \mathrm{O}_{3}$ & 0 & 1.430 \\
$\mathrm{~K}^{+}$ & $\mathrm{K}^{+} \mathrm{NO}_{3}^{-}$ & +1 & 2.586 \\
$\mathrm{Mg}^{2+}$ & $\mathrm{Mg}(\mathrm{OH})_{2}$ & 0 & 2.399 \\
$\mathrm{Mn}^{2+}$ & $\mathrm{Mn}(\mathrm{OH})_{2}$ & 0 & 1.619 \\
$\mathrm{Na}^{+}$ & $\mathrm{Na}{ }^{+} \mathrm{NO}_{3}^{-}$ & +1 & 3.697 \\
$\mathrm{Th}^{4+}$ & $\mathrm{Th}(\mathrm{OH})_{4}$ & 0 & 1.293 \\
$\mathrm{UO}_{2}{ }^{2+}$ & $\mathrm{UO}$ & $\left((\mathrm{OH})_{2}-\mathrm{H}_{2} \mathrm{O}\right.$ & 0 \\
\hline
\end{tabular}

Table 6 summarizes the mass and charge balance for the $\mathrm{Cl}$ and $\mathrm{C} 2$ tank sludge samples. Considering the limitations of these calculations, the mass balance is excellent for these sludge samples and well within the analytical error of the measurements. The charge balance is more sensitive to the chemical form assumptions and the results show a larger corresponding error range.

Table 6 Summary of Quality Checks for C1 and C2 Sludge Data

\begin{tabular}{|c|c|c|c|c|c|c|}
\hline Tank & $\begin{array}{c}\text { Mass } \\
\text { Balance } \\
\left(\mathrm{TS}_{\text {calc }} / \mathrm{TS}_{\text {meas }}\right)\end{array}$ & $\begin{array}{l}\text { Charge } \\
\text { Balance } \\
\left(\mathbf{M}^{+} / \mathbf{A}^{-}\right)\end{array}$ & pH & $\begin{array}{c}{ }^{134} \mathrm{Cs}+{ }^{137} \mathrm{Cs} \\
(\%)\end{array}$ & $\begin{array}{c}{ }^{90} \mathrm{Sr}{ }^{\rho 0} \mathrm{Y} \\
(\%)\end{array}$ & $\begin{array}{c}\text { Beta } \\
\text { Recovery } \\
(\%)\end{array}$ \\
\hline C1-East & 0.958 & 0.760 & 9.9 & 14.2 & 62.4 & 95.3 \\
\hline C1-West & 0.995 & 0.928 & 10.9 & 25.1 & 52.9 & 94.6 \\
\hline C2-East & 0.998 & 0.964 & 12.5 & 23.6 & 37.9 & 99.6 \\
\hline C2-West & 0.959 & 0.938 & 12.1 & 18.0 & 48.4 & 102.3 \\
\hline
\end{tabular}


The beta recovery results are also listed in Table 6 for the $\mathrm{C} 1$ and $\mathrm{C} 2$ sludge samples. There is some variability for the beta recovery which is probably due to the analytical error on the ${ }^{90} \mathrm{Sr}$ measurement. The impact of the analytical error for the ${ }^{90} \mathrm{Sr}$ activity on the beta recovery calculation would be doubled because of the ${ }^{90} \mathrm{Y}$ in secular equilibrium with the strontium. Considering the overall potential for propagated error, the comparison of the gross beta to the summation of the identified radionuclides was excellent for the these sludge samples.

The distribution of the major compounds (listed in Table 5) by weight percent are illustrated in Fig. 4 for each sludge sample. These $\mathrm{C} 1$ and $\mathrm{C} 2$ sludge sample are similar to most ORNL sludge waste in that the sodium/potassium nitrate and calcium carbonate accounts for most of the sludge mass and volume. The balance of the sludge mass is dominated by the uranium and thorium content. The distribution of the total uranium and thorium concentration for the $\mathrm{C} 1$ and $\mathrm{C} 2$ sludge samples are shown in Fig. 5. 
Figure 4 Distribution of Major Compounds in $\mathrm{C} 1$ and $\mathrm{C} 2$ Sludge

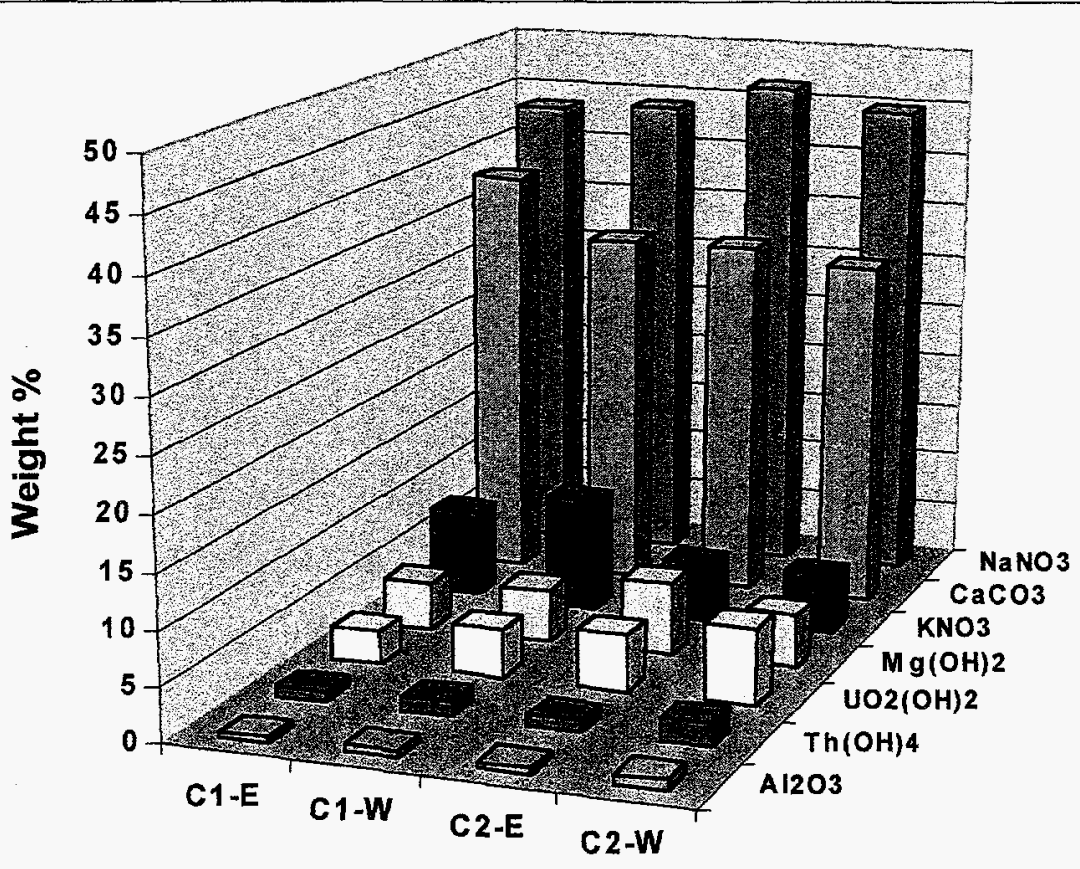

Figure 5 Distribution of Uranium and Thorium in $\mathrm{C} 1$ and $\mathrm{C} 2$ Sludge

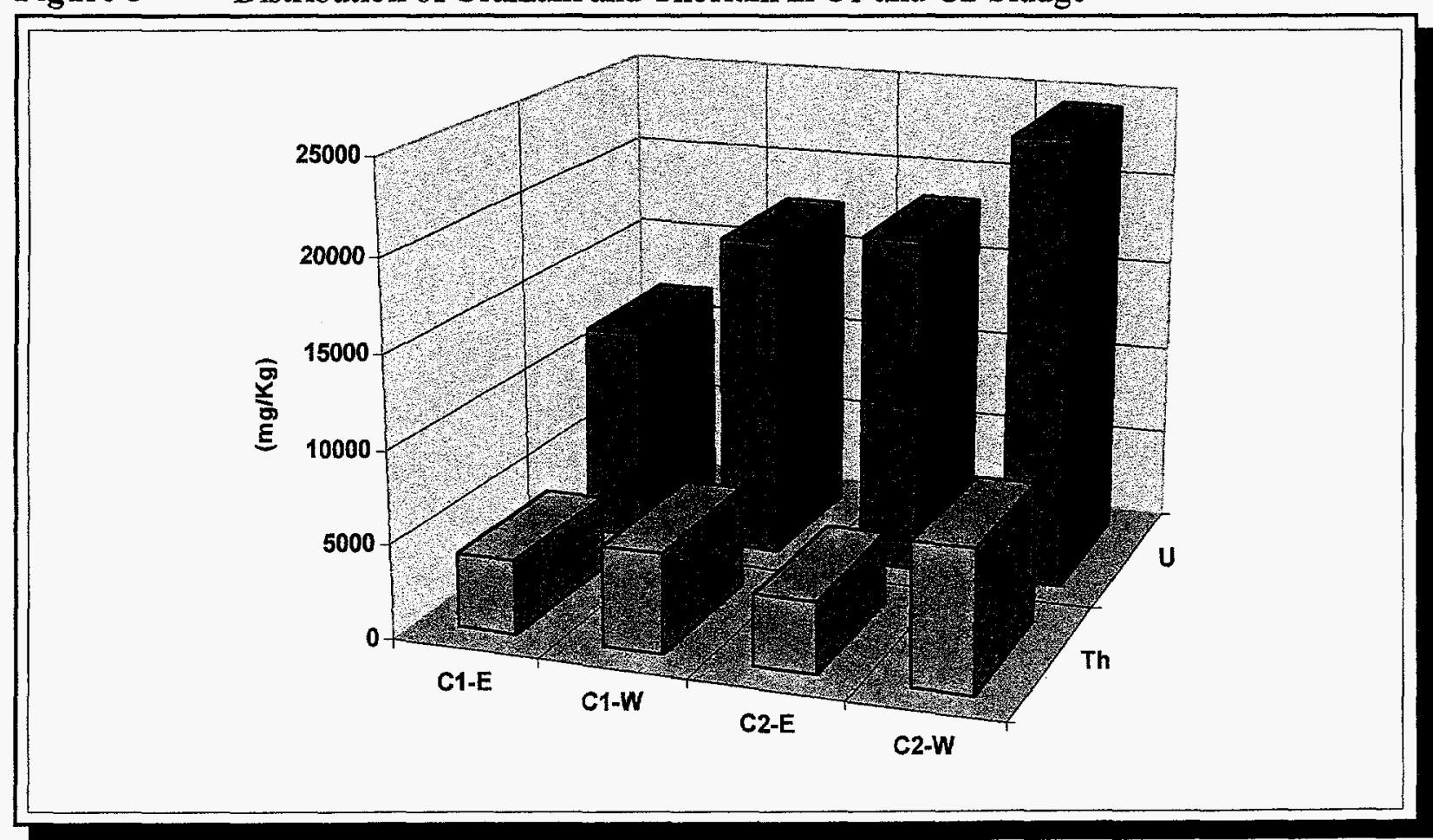


The distribution of the beta emitters found in the $\mathrm{C} 1$ and $\mathrm{C} 2$ sludge samples are summarized in Table 7. Considering the typical basic conditions for ORNL waste tanks, the major difference in the beta distribution between the supernatant and the sludge is that the distribution of the longer lived fission products $\left({ }^{90} \mathrm{Sr}\right.$ and $\left.{ }^{137} \mathrm{Cs}\right)$ are reversed due to the differences in solubility. The Group IA metals $\left({ }^{134} \mathrm{Cs}\right.$ and $\left.{ }^{137} \mathrm{Cs}\right)$ and the radionuclides that form anionic species $\left({ }^{99} \mathrm{TcO}_{4}-{ }^{129} \mathrm{I}^{-}\right.$, and $\left.{ }^{129} \mathrm{IO}_{3}{ }^{-}\right)$are more soluble in the supernatant. The solubility of the Group IIA metals $\left({ }^{90} \mathrm{Sr}\right)$ in the supernatant are a function of both $\mathrm{pH}$ and carbonate concentration. At high $\mathrm{pH}$ most of the other metals, lanthanides, and actinide elements form insoluble hydroxides and mixed oxides, which are found in the sludge. The shorter lived radionuclides observed include the europium $\left({ }^{152} \mathrm{Eu},{ }^{154} \mathrm{Eu}\right.$, and $\left.{ }^{155} \mathrm{Eu}\right)$ isotopes and to some extent ${ }^{134} \mathrm{Cs}$. The distribution of beta activity observed in these sludge samples are typical of the sludge generally found in the ORNL active waste system.

Table 7 Distribution of Beta Activity in Sludge

\begin{tabular}{|c|c|c|c|c|c|c|c|}
\hline \multirow{2}{*}{ Tank } & \multirow{2}{*}{$\mathbf{p H}$} & \multicolumn{5}{|c|}{ Percent of Total Beta Activity } & \multirow{2}{*}{$\begin{array}{c}\mathrm{U} \\
(\mathrm{mg} / \mathrm{Kg})\end{array}$} \\
\hline & & $\begin{array}{l}{ }^{60} \mathrm{Co} \\
(\%)\end{array}$ & $\begin{array}{c}{ }^{90} \mathrm{Sr} /{ }^{90} \mathrm{Y} \\
(\%)\end{array}$ & $\begin{array}{c}{ }^{137} \mathrm{Cs} \\
(\%)\end{array}$ & $\begin{array}{c}{ }^{152,154,155} \mathrm{Eu} \\
(\%)\end{array}$ & $\begin{array}{c}{ }^{241} \mathrm{Pu} \\
(\%)\end{array}$ & \\
\hline C1-East & 9.9 & 1.1 & 62.4 & 14.0 & 21.8 & 0.4 & 11800 \\
\hline C1-West & 10.9 & 0.6 & 52.9 & 24.6 & 20.7 & 0.5 & 17600 \\
\hline C2-East & 12.5 & 1.0 & 37.9 & 22.9 & 36.6 & 0.6 & 18400 \\
\hline C2-West & 12.1 & 1.1 & 48.4 & 17.4 & 31.2 & 1.0 & 24300 \\
\hline
\end{tabular}

The distribution of the alpha activity for the $\mathrm{C} 1$ and $\mathrm{C} 2$ sludge samples are summarized in Table 8 by radionuclide as the relative percent alpha. In general, the alpha activity in ORNL sludge waste is strongly weighted by the ${ }^{244} \mathrm{Cm}$ which has the highest specific activity. The list of actinides in Table 8 required several radiochemical and inorganic analytical measurements to generate the best estimates for each of the alpha activities. The ${ }^{232} \mathrm{Th}$ activity was calculated from the total thorium measured by ICP-AES. The other thorium isotopes $\left({ }^{228} \mathrm{Th},{ }^{229} \mathrm{Th}\right.$, and $\left.{ }^{230} \mathrm{Th}\right)$ are present in the ORNL sludge waste at such low mass, their presence would not effect the ICP-AES measurements. The uranium isotopes were measured by TIMS or ICP-MS. The atom $\%$ results were then converted to weight $\%$ and used to calculate the concentration of each uranium isotope from the total uranium 
results obtained by ICP-AES. The activity for each uranium radionuclide is then calculated from the specific activity for each isotope. The plutonium isotopes were first measured by TIMS or ICPMS, and then along with the total plutonium alpha activity measured after a chemical separation was used to calculate the activity for each plutonium isotope. The ${ }^{244} \mathrm{Cm}$ was measured directly by alpha spectrometry without any chemical separation. The ${ }^{241} \mathrm{Am}$ activity was determined by subtracting the ${ }^{238} \mathrm{Pu}$ activity from the sum of the ${ }^{238} \mathrm{Pu}+{ }^{241} \mathrm{Am}$ measured by alpha spectrometry. Both ${ }^{238} \mathrm{Pu}$ and ${ }^{241} \mathrm{Am}$ have an alpha energy of about $5.50 \mathrm{MeV}$ and can not be resolved by alpha spectrometry and there were no chemical separations done for the plutonium and americium for this project because of cost constraints.

Table 8 Summary of Actinide Elements in BVEST Sludge

\begin{tabular}{|c|c|c|c|c||}
\hline \multirow{2}{*}{ Actinide } & C1-East & C1-West & C2-East & C2-West \\
\cline { 2 - 5 } & $(\% \alpha)$ & $(\% \alpha)$ & $(\% \alpha)$ & $(\% \alpha)$ \\
\hline \hline${ }^{232} \mathrm{Th}$ & 0.02 & 0.03 & 0.02 & 0.02 \\
${ }^{233} \mathrm{U}$ & 11.82 & 35.00 & 8.42 & 8.98 \\
${ }^{234} \mathrm{U}$ & 0.26 & 0.52 & 0.29 & 0.17 \\
${ }^{235} \mathrm{U}$ & $<0.01$ & 0.01 & $<0.01$ & $<0.01$ \\
${ }^{238} \mathrm{U}$ & 0.22 & 0.27 & 0.26 & 0.19 \\
${ }^{237} \mathrm{~Np}$ & $<0.01$ & $<0.01$ & $<0.01$ & $<0.01$ \\
${ }^{238} \mathrm{Pu}$ & 10.28 & 9.25 & 12.69 & 9.10 \\
${ }^{239} \mathrm{Pu}$ & 1.26 & 1.43 & 1.87 & 2.47 \\
${ }^{240} \mathrm{Pu}$ & 1.24 & 0.84 & 1.54 & 2.27 \\
${ }^{241} \mathrm{Am}$ & 6.39 & 9.29 & 13.92 & 7.55 \\
${ }^{244} \mathrm{Cm}$ & 68.49 & 43.36 & 60.98 & 69.23 \\
\hline \hline Gross $\alpha(\mathrm{Bq} / \mathrm{g})$ & 67000 & 84000 & 88000 & 160000 \\
\hline \hline
\end{tabular}

${ }^{a}$ The ${ }^{241} \mathrm{Am}$ data is based on subtracting the ${ }^{238} \mathrm{Pu}$ by ICP-MS from the alpha peak measured at 5.15 $\mathrm{MeV}\left({ }^{238} \mathrm{Pu}+{ }^{241} \mathrm{Am}\right)$ in the alpha spectrum. 


\subsection{RCRA Characteristics for the C1 and C2 Sludge}

The RCRA regulatory limits are listed in Table 9, which also includes the limits for the EPA Toxicity Characteristic Leaching Protocol (TCLP) extract and the functional total metal limits for a solid or sludge waste. Because of the 1:20 dilution used for the TCLP extraction procedure, the total metal limits for sludge samples are twenty times higher than the TCLP extraction limits.

Table 9 Summary of RCRA Regulatory Limits

\begin{tabular}{|ll|c|c||}
\hline Metals & & $\begin{array}{c}\text { TCLP Extract } \\
\text { and Liquids } \\
\text { (mg/L) }\end{array}$ & $\begin{array}{c}\text { Solid/Sludge } \\
\text { Total Metal } \\
\text { (mg/Kg) }\end{array}$ \\
\hline \hline Silver & $(\mathrm{Ag})$ & 5 & 100 \\
Arsenic & $(\mathrm{As})$ & 5 & 100 \\
Barium & $(\mathrm{Ba})$ & 100 & 2000 \\
Cadmium & $(\mathrm{Cd})$ & 1 & 20 \\
Chromium & $(\mathrm{Cr})$ & 5 & 100 \\
Mercury & $(\mathrm{Hg})$ & 0.2 & 4 \\
Nickel & $(\mathrm{Ni})$ & 50 & 1000 \\
Lead & $(\mathrm{Pb})$ & 5 & 100 \\
Selenium & $(\mathrm{Se})$ & 1 & 20 \\
Thallium & $(\mathrm{Tl})$ & 0.9 & 18 \\
\hline
\end{tabular}

If the RCRA metal concentrations are found to be below the total metal limits, the solid waste can not fail the TCLP leach test. If the RCRA metal concentrations exceed the total metal limits, the TCLP leach test must be done to determine if the solid waste is hazardous. For solid samples, the TCLP leach test is only valid for the final waste form ready for disposal. The total metal concentration data can be used as acceptable process knowledge if the final waste form only results in a dilution of the RCRA metal concentrations. Examples of waste forms that result in a dilution of a solid waste includes grouting ( 2 fold dilution) and vitrification ( 3 fold dilution). If the total 
metal limit is exceeded after stabilizing the waste, the TCLP leach test would be required for only the metals that had the potential to exceed the regulatory limits.

Both of the $\mathrm{C} 1$ tank sludge samples exceed the total metal limits for chromium, lead, and mercury. The C2 sludge samples exceed the total metal limits for cadmium, chromium, lead, and mercury Most of the ORNL radioactive waste sludge samples characterized to date have exceeded the total metal limits for these RCRA metals. Based on past experience, it is expected that solidification of the most ORNL sludge would fix these RCRA metals such that the final waste form would pass a TCLP leach test.

\subsection{TRU Classifications for C1 and C2 Sludge}

The DOE definition for Transuranic (TRU) Waste includes the following conditions,

- TRU activity $>3700 \mathrm{~Bq} / \mathrm{g}(100 \mathrm{nCi} / \mathrm{g})$,

- TRU isotopes must be alpha emitting actinides with $Z>92$ (uranium),

- TRU isotopes must have a half life $\geq 20$ years.

This definition excludes all thorium and uranium isotopes. The short lived actinide ${ }^{244} \mathrm{Cm}\left(\mathrm{t}_{1 / 2}=18.1\right.$ years), which is common to ORNL waste, falls outside the TRU definition. Also, the plutonium isotope, ${ }^{241} \mathrm{Pu}$, would be excluded from calculation of the TRU activity because it is a pure beta emitter. The primary actinide elements common to ORNL waste, that are present at sufficient levels to meet the TRU definition, include ${ }^{238} \mathrm{Pu},{ }^{239} \mathrm{Pu},{ }^{240} \mathrm{Pu}$, and ${ }^{241} \mathrm{Am}$. There is some recent work at the Radiochemical Engineering Development Center (Mark-42 fuel assembly processing) that could generate enough ${ }^{243} \mathrm{Am}$ to make a significant contribution to TRU alpha content of the waste. The remaining actinide elements present in ORNL waste are generally not available at high enough activity, and/or do not have a long enough half-life to meet the TRU definition.

All of the $\mathrm{C} 1$ and $\mathrm{C} 2$ sludge samples characterized for this project were classified as TRU waste based on only the plutonium and americium activity. The alpha activity reported is based on wet weight and if adjusted for dry weight the TRU activity would almost double. The $\mathrm{C} 1$ and $\mathrm{C} 2$ sludge samples contained enough plutonium and americium activity to easily satisfy the WIPP waste 
acceptance criteria ${ }^{13}$ for transuranic waste. Based on the TRU activity, any dilution of the sludge that would result from a solidification process such as grouting or vitrification would most likely not effect the TRU classification.

\subsection{Distribution of Fissile Material in C1 and C2 Sludge}

The ORNL LLLW waste acceptance criteria (WAC) requires the fissile isotopes of uranium and plutonium to be diluted with ${ }^{238} \mathrm{U}$ and ${ }^{232} \mathrm{Th}$, respectively. A summary of the dilution ratios for fissile material in the BVEST sludge samples are provided in Table 10. All the dilution ratios for the BVEST sludge samples exceeded the required dilution factors for the fissile isotopes of uranium and plutonium except for the $\mathrm{C} 1$-West uranium ratios which were low because of the additional ${ }^{233} \mathrm{U}$ in the sample. All the dilution ratios listed in Table 10 are based on equations discussed in section 3.5 of this report.

Table 10 Summary of Denature Ratios for C1 and C2 Sludge

\begin{tabular}{|l|c|c|c|c|c|}
\hline Tank & $\begin{array}{c}{ }^{238} \mathbf{U}{ }^{235} \mathbf{U} f_{35} \\
\text { (eq. 1) }\end{array}$ & $\begin{array}{c}{ }^{238} \mathbf{U}{ }^{235} \mathbf{U} \\
\text { (eq. 3) }\end{array}$ & $\begin{array}{c}{ }^{238} \mathbf{U}{ }^{233} \mathbf{U} \\
\text { (eq. 4) }\end{array}$ & $\begin{array}{c}{ }^{232} \mathbf{T h}{ }^{239} \mathbf{P u} \\
\text { (eq. 2) }\end{array}$ & pH \\
\hline C1-East & 198 & 248 & 389 & 11065 & 9.9 \\
C1-West & 105 & 27 & 137 & 10658 & 10.9 \\
C2-East & 216 & 248 & 586 & 5382 & 12.5 \\
C2-West & 167 & 179 & 356 & 4379 & 12.1 \\
\hline
\end{tabular}

The dilution ratios listed in Table 10 are based on the ratio of weight $\%$, not the ratio of atom $\%$ given in the data tables. There is a small difference between atom $\%$, reported for the uranium and plutonium, and weight $\%$, which is needed for many calculations performed with the analytical data. To convert from atom $\%$ to weight $\%$, we used the following equation, 


$$
W_{i}=\frac{a_{i} M_{i}}{\sum_{i}^{n} a_{i} M_{i}} X 100 \%
$$

$$
\text { where, } \quad \begin{array}{ll}
\mathrm{W}_{\mathrm{i}} & =\text { weight } \%, \\
\mathrm{M}_{\mathrm{i}} & =\text { nuclidic mass } \\
\mathrm{a}_{\mathrm{i}} & =\text { atom } \% .
\end{array}
$$

An example of this calculation is provided in Table 11, which shows there is not much difference between the atom $\%$ and the weight $\%$.

Table 11 Example of Converting Atom \% to Weight \% for Typical Sludge

\begin{tabular}{|c|c|c|r|r||}
\hline Isotope & $\begin{array}{c}\text { Nuclidic mass } \\
(\mathbf{g} / \mathbf{m o l})\end{array}$ & atom \% & $\left.\mathbf{( a}_{\mathbf{i}} \mathbf{M}_{\mathbf{i}}\right)$ & weight $\%$ \\
\hline \hline${ }^{233} \mathrm{U}$ & 233.039629 & 0.056 & 13.0502 & 0.0548 \\
${ }^{234} \mathrm{U}$ & 234.040947 & 0.004 & 0.9362 & 0.0039 \\
${ }^{235} \mathrm{U}$ & 235.043924 & 0.621 & 145.9623 & 0.6132 \\
${ }^{236} \mathrm{U}$ & 236.045563 & 0.002 & 0.4721 & 0.0020 \\
${ }^{238} \mathrm{U}$ & 238.050785 & 99.316 & 23642.2518 & 99.3260 \\
& & 99.999 & 23802.6726 & 99.9999 \\
\hline
\end{tabular}

The distribution of plutonium isotopes by alpha activity are illustrated in Fig. 6 for each of the $\mathrm{C} 1$ and $\mathrm{C} 2$ sludge samples. For comparison, Fig. 7 shows the distribution of the plutonium isotopes by concentration for each of the $\mathrm{C} 1$ and $\mathrm{C} 2$ sludge samples. One should note that the ${ }^{238} \mathrm{Pu}$ dominates the alpha activity and the ${ }^{239} \mathrm{Pu}$ is the major isotope by weight or concentration. 
Figure 6 Distribution of Plutonium Alpha Activity in the C1 and C2 Sludge

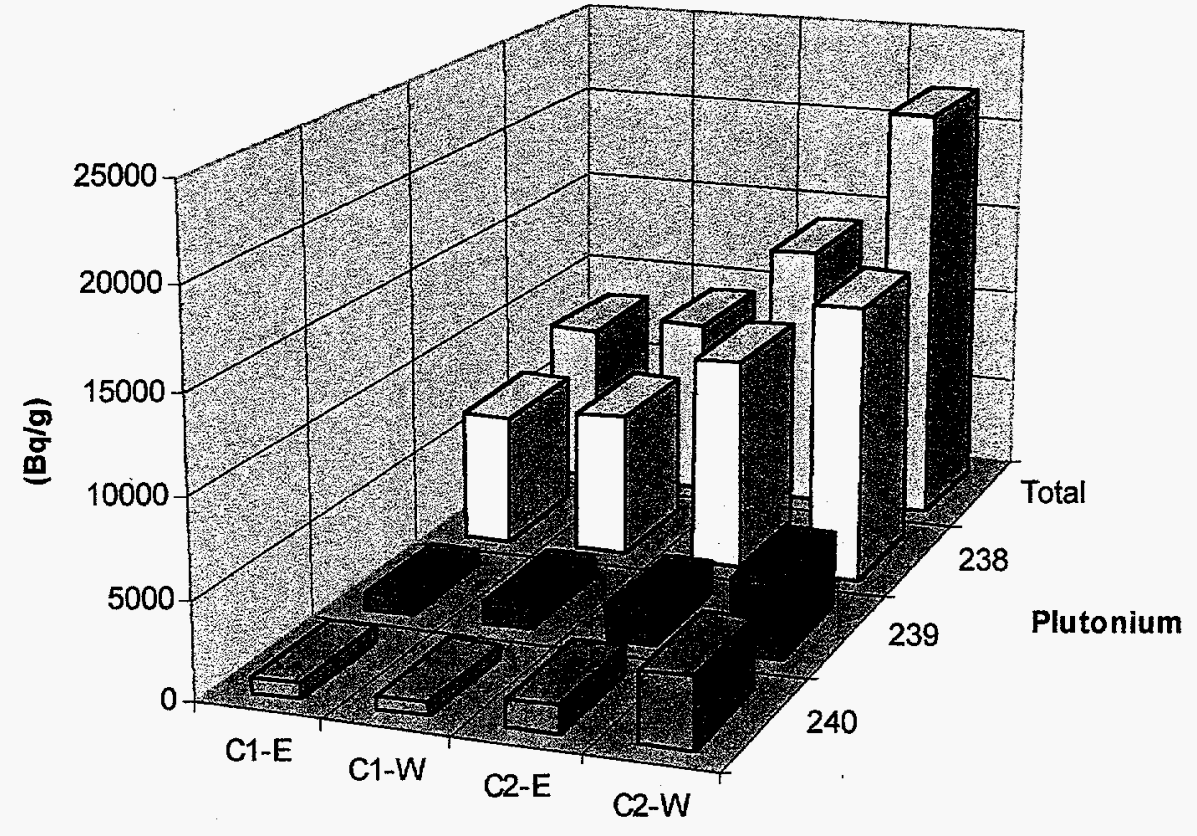

Figure 7 Distribution of Plutonium by Concentration in the $\mathrm{C} 1$ and C2 Sludge

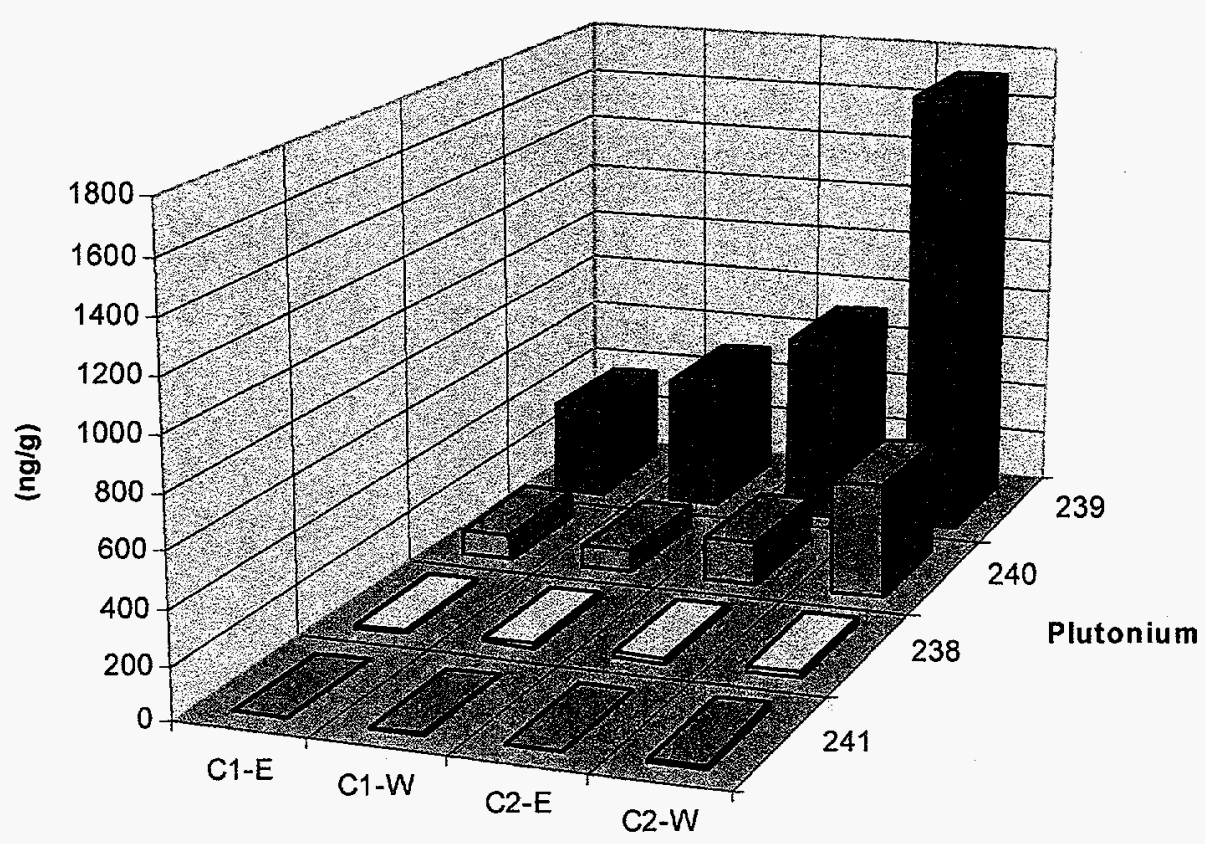




\subsection{Discussion of the Total Anion Content in the Sludge}

As discussed in section 3.3, there were several sample preparation methods used to investigate the total anion content of the $\mathrm{C} 1$ and $\mathrm{C} 2$ sludge samples. These preparation methods included (1) a water leach, (2) a caustic sodium peroxide fusion, and a (3) nitric acid microwave dissolution for the total phosphorus as phosphate and sulfur as sulfate content. A summary and comparison of these sludge preparation methods are given in Table 12.

Table 12 Summary of Total Anion Data for C1 and C2 Sludge

\begin{tabular}{|c|c|c|c|c|c|}
\hline \multirow[t]{2}{*}{ Anion } & \multirow[t]{2}{*}{ Method } & \multicolumn{4}{|c|}{$(\mathrm{mg} / \mathrm{Kg})$} \\
\hline & & C1-East & C1-West & C2-East & C2-West \\
\hline Bromide & $\begin{array}{l}\text { Water Leach } \\
\text { Fusion }\end{array}$ & $\begin{array}{l}<48 \\
<42\end{array}$ & $\begin{array}{l}<48 \\
263\end{array}$ & $\begin{array}{r}<50 \\
383\end{array}$ & $\begin{array}{r}<48 \\
234\end{array}$ \\
\hline Chloride & $\begin{array}{l}\text { Water Leach } \\
\text { \% Leached } \\
\text { Fusion }\end{array}$ & $\begin{array}{c}2810 \\
83.6 \\
3360\end{array}$ & $\begin{array}{l}3140 \\
91.8 \\
3420\end{array}$ & $\begin{array}{c}4800 \\
94.9 \\
5060\end{array}$ & $\begin{array}{c}4440 \\
98.9 \\
4490\end{array}$ \\
\hline Fluoride & $\begin{array}{l}\text { Water Leach } \\
\text { \% Leached } \\
\text { Fusion }\end{array}$ & $\begin{array}{r}<48 \\
- \\
567\end{array}$ & $\begin{array}{c}54 \\
4.6 \\
1180\end{array}$ & $\begin{array}{r}<50 \\
- \\
549\end{array}$ & $\begin{array}{c}87 \\
19.9 \\
437\end{array}$ \\
\hline Nitrate & Water Leach & 195000 & 161000 & 134000 & 124000 \\
\hline Nitrite & Water Leach & 1090 & 1860 & 313 & 3140 \\
\hline Phosphate & $\begin{array}{l}\text { Water Leach } \\
\mathrm{HNO}_{3}\end{array}$ & $\begin{array}{r}<10 \\
4180 \\
\end{array}$ & $\begin{array}{r}<10 \\
4740 \\
\end{array}$ & $\begin{array}{r}16 \\
7950 \\
\end{array}$ & $\begin{array}{r}<10 \\
11700 \\
\end{array}$ \\
\hline Sulfate & $\begin{array}{l}\text { Water Leach } \\
\text { \% Leached } \\
\text { Fusion } \\
\mathrm{HNO}_{3} \\
\end{array}$ & $\begin{array}{c}1230 \\
31.3 \\
3930 \\
3660 \\
\end{array}$ & $\begin{array}{c}1800 \\
52.0 \\
3460 \\
3910 \\
\end{array}$ & $\begin{array}{c}5540 \\
70.9 \\
7810 \\
8640 \\
\end{array}$ & $\begin{array}{c}5110 \\
62.4 \\
8190 \\
8000 \\
\end{array}$ \\
\hline
\end{tabular}

\subsubsection{Nitrate/Nitrite}

The majority of the anion contribution is by far due to the nitrate/nitrite ions with the other anions contributing just a fraction of the total negative molar charge. Based on the calculated charge balance it is believed that the majority of the nitrates are accounted for with the water leaches. 


\subsubsection{Halides (fluoride, chloride, bromide)}

As illustrated by the data in Table 12 all the halides show a higher result with the caustic fusion preparation. However, most of chloride was soluble in the water leach and very little of the fluoride was observed in the water preparation. This type of halide behavior was expected based on the solubility properties of most binary metal-halide compounds.

\subsubsection{Phosphate}

It is believed that a significant fraction of the phosphate in the $\mathrm{C} 1 / \mathrm{C} 2$ sludge is present as tributyl phosphate and degradation products dibutyl-and monobutyl phosphate. The tributyl phosphate has a low solubility in water and would not be seen in the water leach, and is consistent with the data in Table 12 where phosphate values are below or near the detection limit of the analytical method. However, it is difficult to develop any conclusions concerning the phosphate because most metalphosphates, with the exception of Group I metals, are water insoluble.

If the sludge samples were prepared using closed vessel microwave acid digestion followed with analysis by ion chromatography the highest results for total phosphate were observed. These phosphate results based on the analysis of total phosphorus after total digestion are currently considered to be the best results for the total phosphorus in the sludge.

\subsubsection{Sulfate}

Both the caustic fusion or the nitric acid digestion seemed to be suitable for the total sulfur as sulfate determination. Even the water leach was fairly efficient at removing sulfate with the water soluble fraction ranging from about $30 \%-70 \%$. Although the calcium, which was a major component of the sludge, forms insoluble compounds with sulfate, most of the calcium was bound up with the carbonate present.

\subsubsection{Summary}

There is no ideal single method to obtain a total anion content on the $\mathrm{C} 1 / \mathrm{C} 2$ sludge. The water leaches are considered to be good for nitrate and nitrite, and fair for the chloride and sulfate. The phosphate content can not be obtained by a water leach and the water soluble sulfate ranges from 
poor to fair. The best preparation method for total phosphorus or sulfur appears to be closed vessel microwave digestion followed by analysis by ICP-AES, ICP-MS, or ion chromatography with the appropriate column. The best results for halide compounds is the caustic fusion follow by ion chromatography, especially for the bromide and fluoride.

\subsection{Estimates for Compliance with WIPP WAC, Rev. 5 for BVEST Sludge}

The purpose of this section is to establish upper boundary estimates, based upon a 55-gal. drum shipping container, for several of the preliminary nuclear properties criteria and requirements for RH-TRU waste as specified in the WIPP WAC, Revision 5. Specifically, this section will develop estimates for the ${ }^{239} \mathrm{Pu}$ Fissile Gram Equivalent (FGE) ${ }^{239} \mathrm{Pu}$ Equivalent Activity, and Thermal Power or decay heat limits per RH-TRU canister. The preliminary RH-TRU limits per waste canister for each of these nuclear criteria are listed as follows,

$\begin{array}{lll}\text { - } & { }^{239} \mathrm{Pu} \text { FGE } & <325 \mathrm{~g} \\ \text { - } & { }^{239} \mathrm{Pu} \text { Equivalent Activity } & <1000 \mathrm{Ci} \\ \text { - } & \text { Thermal Power } & <300 \text { watts. }\end{array}$

For the BVEST sludge, the ${ }^{239} \mathrm{Pu}$ FGE can be estimated by the summation of the gram-equivalents for ${ }^{233} \mathrm{U},{ }^{235} \mathrm{U}$, and ${ }^{239} \mathrm{Pu}$. As shown in Table 13, the ${ }^{235} \mathrm{U}$ dominates the total ${ }^{239} \mathrm{Pu}$ FGE for the BVEST sludge samples and the ${ }^{239} \mathrm{Pu}$ is less than $5 \%$ of the total fissile gram equivalent. Based on packaging the wet sludge in 55-gal. drums, none of the BVEST sludge would approach the RH-TRU limit of $325 \mathrm{~g}$ per canister for the ${ }^{239} \mathrm{Pu}$ FGE. Estimates for the total weight $(\mathrm{Kg})$ of sludge in a 55 gal. drum, for each sludge sample, are listed in Table 16.

Estimates for the total ${ }^{239} \mathrm{Pu}$ equivalent activity (Ci) in a 55-gal. drum for each of the BVEST sludge samples are listed in Table 14 . The ${ }^{239} \mathrm{Pu}$ equivalent activity is based on following calculation,

$$
{ }^{239} \mathrm{Pu} \text { Equivalent Activity }=\sum_{i=1} \frac{A_{i}}{F_{i}}
$$

where $\mathrm{A}_{\mathrm{i}}$ is the activity of radionuclide $i$, and $\mathrm{F}_{\mathrm{i}}$ is the ${ }^{239} \mathrm{Pu}$ equivalent activity weighting factor for radionuclide $i$. The weighting factors for the major radionuclides found in the $\mathrm{C} 1$ and $\mathrm{C} 2$ sludge are 
listed in Table 15. As shown in the last row of Table 15, all of the $\mathrm{C} 1$ and $\mathrm{C} 2$ sludge estimates for ${ }^{239} \mathrm{Pu}$ Equivalent activity would be less than $1 \mathrm{Ci}$ per $55 \mathrm{gal}$. drum, which is well below the RH-TRU limits. These sludge estimates are also well below the CH-TRU limit of $80 \mathrm{Ci}$ of plutonium equivalent activity for untreated waste in a 55-gal. drum and would not approach the $1000 \mathrm{Ci} \mathrm{WAC}$ limit for a RH-TRU canister, which holds three 55-gal. drums.

There is concern about the thermal power from the decay heat of the radionuclides present in waste packages prepared for WIPP disposal. These concerns are addressed in Revision 5 of the WIPP WAC, with limits of 40 watts for a TRUPACT-II container for CH-TRU waste and a limit of 300 watts for a RH-TRU canister. High decay heat is also an indicator for potential problems with hydrogen gas generation. The major radionuclides found in the $\mathrm{C} 1$ and $\mathrm{C} 2$ sludge are listed in Table 15 along with the " $Q$ " values needed to calculate the decay heat for each isotope.

An estimate of the decay heat distribution by radionuclide for the $\mathrm{C} 1$ and $\mathrm{C} 2$ sludge samples are listed in Table 16 along with an upper boundary for total decay heat that could be expected in a 55 gal. drum full of wet sludge. These estimates indicate that the decay heat from sludge is far below any of the WIPP WAC limits for thermal power and should have no impact on packaging requirements. For general interest, the relative percent distributions of the decay heat by radionuclide, beta activity, and alpha activity are listed in Table 17. The distribution of decay heat as a function of the radionuclide is illustrated in Fig. 8 for beta decay, and in Fig. 9 for alpha decay. It is interesting to note that the beta activity accounts for most of the decay heat output and that the heat from alpha decay is generally less than $15 \%$ of the total thermal power. 
Table 13 Estimates for ${ }^{239} \mathrm{Pu}$ FGE Content in the $\mathrm{C} 1$ and $\mathrm{C} 2$ Sludge

\begin{tabular}{|l|c|c|c|c|c||}
\hline Isotope & $\begin{array}{c}{ }^{239} \mathbf{P u} \text { FGE } \\
\text { factor }\end{array}$ & $\begin{array}{c}\text { C1-East } \\
(\mathbf{m g} / \mathbf{K g})\end{array}$ & $\begin{array}{c}\text { C1-West } \\
(\mathbf{m g} / \mathbf{K g})\end{array}$ & $\begin{array}{c}\text { C2-East } \\
\text { (mg/Kg) }\end{array}$ & $\begin{array}{c}\text { C2-West } \\
\text { (mg/Kg) }\end{array}$ \\
\hline${ }^{233} \mathrm{U}$ & 0.865 & 21.8 & 79.2 & 20.5 & 40.0 \\
\hline${ }^{235} \mathrm{U}$ & 0.641 & 26.6 & 53.4 & 50.9 & 80.3 \\
\hline${ }^{239} \mathrm{Pu}$ & 1.000 & $\mathbf{0 . 3 6}$ & 0.50 & 0.71 & 1.7 \\
\hline \hline${ }^{239} \mathrm{Pu}$ FGE (mg/Kg) & 36.3 & 103 & 51.1 & $\mathbf{8 7 . 8}$ \\
\hline${ }^{239} \mathrm{Pu}$ FGE in 55 gal. (g) & $\mathbf{1 1 . 8}$ & $\mathbf{3 3 . 1}$ & $\mathbf{1 5 . 7}$ & $\mathbf{2 7 . 4}$ \\
\hline
\end{tabular}

Table 14 Estimates for ${ }^{239} \mathrm{Pu}$ Equivalent Activity with the BVEST Sludge

\begin{tabular}{|l|c|c|c|c|c|}
\hline Isotope & $\begin{array}{c}{ }^{239} \mathbf{P u} \\
\text { wt. factor }\end{array}$ & $\begin{array}{c}\text { C1-East } \\
(\mathbf{B q} / \mathbf{g})\end{array}$ & $\begin{array}{c}\text { C1-West } \\
(\mathbf{B q} / \mathbf{g})\end{array}$ & $\begin{array}{c}\text { C2-East } \\
(\mathbf{B q} / \mathbf{g})\end{array}$ & $\begin{array}{c}\text { C2-West } \\
(\mathbf{B q} / \mathbf{g})\end{array}$ \\
\hline${ }^{233} \mathrm{U}$ & 3.9 & 7760 & 28200 & 7320 & 14300 \\
\hline${ }^{238} \mathrm{Pu}$ & 1.1 & 6750 & 7470 & 11000 & 14500 \\
\hline${ }^{239} \mathrm{Pu}$ & 1.0 & 828 & 1150 & 1630 & 3930 \\
\hline${ }^{240} \mathrm{Pu}$ & 1.0 & 818 & 675 & 1340 & 3600 \\
\hline${ }^{241} \mathrm{Pu}$ & 52.0 & 15400 & 15100 & 25700 & 56500 \\
\hline${ }^{241} \mathrm{Am}$ & 1.0 & 4200 & 7500 & 12100 & 12000 \\
\hline${ }^{244} \mathrm{Cm}$ & 1.9 & 45000 & 35000 & 53000 & 110000 \\
\hline${ }^{239} \mathrm{Pu}$ Eqv. (Bq/g) & 37950 & 42060 & 55340 & 91980 \\
\hline${ }^{239} \mathrm{Pu}$ Eqv. in 55 gal. (Ci) & $\mathbf{0 . 3 3}$ & $\mathbf{0 . 3 6}$ & $\mathbf{0 . 4 6}$ & $\mathbf{0 . 7 8}$ \\
\hline
\end{tabular}

${ }^{a}$ Radionuclide-specific weighting factors for the ${ }^{239} \mathrm{Pu}$ equivalent activity taken from Appendix $\mathrm{A}$ of DOE/WIPP-069, Rev.5 . 
Table 15 Isotopes that Contribute to the Decay Heat in the C1 and C2 Sludge

\begin{tabular}{|c|c|c|c|c|c|c|}
\hline Isotope & $\begin{array}{c}\text { "Q" value } \\
\text { (W/Ci) }\end{array}$ & $\begin{array}{c}\text { "Q" value } \\
(W / B q)\end{array}$ & $\begin{array}{c}\text { C1-E } \\
\text { (Bq/g) }\end{array}$ & $\begin{array}{c}C 1-W \\
(B q / g)\end{array}$ & $\begin{array}{c}\text { C2-E } \\
(\mathrm{Bq} / \mathrm{g})\end{array}$ & $\begin{array}{l}\text { C2-W } \\
(\mathrm{Bq} / \mathrm{g})\end{array}$ \\
\hline${ }^{60} \mathrm{Co}$ & $1.54 \mathrm{E}-02$ & $4.16 \mathrm{E}-13$ & 4.3E+04 & $2.1 E+04$ & 4.7E+04 & $6.4 E+04$ \\
\hline${ }^{90} \mathrm{Sr}$ & 1.16E-03 & $3.14 \mathrm{E}-14$ & $1.2 E+06$ & $8.8 E+05$ & $8.9 E+05$ & $1.4 E+06$ \\
\hline${ }^{90} \mathrm{Y}$ & 5.54E-03 & $1.50 E-13$ & $1.2 E+06$ & $8.8 E+05$ & $8.9 E+05$ & $1.4 E+06$ \\
\hline${ }^{137} \mathrm{Cs}$ & 1.01E-03 & $2.73 E-14$ & $4.6 E+05$ & $7.0 E+05$ & $9.2 E+05$ & $8.6 E+05$ \\
\hline${ }^{137 \mathrm{~m}} \mathrm{Ba}$ & $3.94 E-03$ & $1.06 E-13$ & $4.6 E+05$ & $7.0 \mathrm{E}+05$ & $9.2 \mathrm{E}+05$ & $8.6 E+05$ \\
\hline${ }^{152} \mathrm{Eu}$ & 7.65E-03 & $2.07 E-13$ & $5.4 E+05$ & $5.2 E+05$ & $1.3 E+06$ & $1.2 E+06$ \\
\hline${ }^{154} \mathrm{Eu}$ & $9.08 E-03$ & $2.45 E-13$ & $2.4 E+05$ & $1.5 E+05$ & $3.8 \mathrm{E}+05$ & $4.8 E+05$ \\
\hline${ }^{155} \mathrm{Eu}$ & 7.59E-04 & $2.05 E-14$ & $3.9 E+04$ & $3.8 E+04$ & $9.3 E+04$ & $9.8 \mathrm{E}+04$ \\
\hline${ }^{24 i} \mathrm{Pu}$ & 3.20E-05 & $8.65 \mathrm{E}-16$ & $1.5 E+04$ & $1.5 E+04$ & $2.6 \mathrm{E}+04$ & $5.7 E+04$ \\
\hline \multicolumn{3}{|c|}{ Gotal beta (Ci/Kg) } & 1.13E-01 & $1.06 \mathrm{E}-01$ & $1.48 E-01$ & $1.73 E=011$ \\
\hline${ }^{233} \mathrm{U}$ & $2.86 E-02$ & $7.72 E-13$ & $7.8 E+03$ & $2.8 E+04$ & $7.3 E+03$ & $1.4 E+04$ \\
\hline${ }^{238} \mathrm{Pu}$ & $3.26 E-02$ & 8.81E-13 & $6.8 E+03$ & $7.5 E+03$ & $1.1 E+04$ & $1.5 E+04$ \\
\hline${ }^{239} \mathrm{Pu}$ & $3.02 E-02$ & $8.17 E-13$ & $8.3 E+02$ & $1.2 E+03$ & $1.6 E+03$ & $3.9 E+03$ \\
\hline${ }^{240} \mathrm{Pu}$ & $3.06 E-02$ & $8.26 E-13$ & $8.2 E+02$ & $6.8 E+02$ & $1.3 E+03$ & $3.6 E+03$ \\
\hline${ }^{241} \mathrm{Am}$ & $3.28 \mathrm{E}-02$ & $8.87 E-13$ & $4.2 E+03$ & $7.5 \mathrm{E}+03$ & $1.2 E+04$ & $1.2 E+04$ \\
\hline${ }^{244} \mathrm{Cm}$ & $3.44 \mathrm{E}-02$ & $9.29 \mathrm{E}-13$ & $4.5 E+04$ & $3.5 E+04$ & $5.3 E+04$ & $1.1 E+05$ \\
\hline \multicolumn{3}{|c|}{ Totollalpha (Ci//Kg) } & 1.77E-03 & $2.16 E-03$ & $2.33 E-03$ & 4.28EE0 3 \\
\hline \multirow{2}{*}{\multicolumn{3}{|c|}{ Total beta in 55 gal. drum (Ci): }} & 36.86 & 33.85 & 45.48 & 54.21 \\
\hline & & & 0.57 & 0.69 & 0.72 & 1.34 \\
\hline
\end{tabular}

Table 16 Distribution of Decay Heat in C1 and C2 Sludge

\begin{tabular}{|c|c|c|c|c|c|c|}
\hline Isotope & $\begin{array}{c}\text { "Q" value } \\
\text { (W/Ci) }\end{array}$ & $\begin{array}{c}\text { "Q" value } \\
\text { (W/Bq) }\end{array}$ & $\begin{array}{c}\text { C1-E } \\
(W / K g)\end{array}$ & $\begin{array}{c}\text { C1-W } \\
(W / K g)\end{array}$ & $\begin{array}{c}\text { C2-E } \\
(W / K g)\end{array}$ & $\begin{array}{l}\mathrm{C2-W} \\
(\mathrm{W} / \mathrm{Kg})\end{array}$ \\
\hline${ }^{60} \mathrm{Co}$ & $1.54 E-02$ & $4.16 E-13$ & 1.79E-05 & $8.75 E-06$ & $1.96 \mathrm{E}-05$ & $2.67 \mathrm{E}-05$ \\
\hline${ }^{90} \mathrm{Sr}$ & 1.16E-03 & $3.14 \mathrm{E}-14$ & $3.76 \mathrm{E}-05$ & $2.76 E-05$ & $2.79 E-05$ & 4.39E-05 \\
\hline${ }^{90} \mathrm{Y}$ & $5.54 \mathrm{E}-03$ & $1.50 E-13$ & $1.80 \mathrm{E}-04$ & $1.32 E-04$ & 1.33E-04 & 2.10E-04 \\
\hline${ }^{137} \mathrm{Cs}$ & $1.01 \mathrm{E}-03$ & $2.73 E-14$ & 1.26E-05 & $1.91 E-05$ & $2.51 E-05$ & $2.35 \mathrm{E}-05$ \\
\hline${ }^{137 \mathrm{mBa}} \mathrm{Ba}$ & $3.94 \mathrm{E}-03$ & $1.06 E-13$ & $4.90 \mathrm{E}-05$ & $7.45 E-05$ & $9.80 \mathrm{E}-05$ & $9.16 \mathrm{E}-05$ \\
\hline${ }^{152} \mathrm{Eu}$ & $7.65 \mathrm{E}-03$ & $2.07 E-13$ & 1.12E-04 & 1.07E-04 & 2.69E-04 & $2.48 \mathrm{E}-04$ \\
\hline${ }^{154} \mathrm{Eu}$ & $9.08 \mathrm{E}-03$ & $2.45 \mathrm{E}-13$ & $5.89 E-05$ & $3.68 \mathrm{E}-05$ & 9.33E-05 & $1.18 \mathrm{E}-04$ \\
\hline${ }^{155} \mathrm{Eu}$ & $7.59 \mathrm{E}-04$ & $2.05 E-14$ & $8.00 E-07$ & $7.80 \mathrm{E}-07$ & $1.91 E-06$ & $2.01 \mathrm{E}-06$ \\
\hline${ }^{241} \mathrm{Pu}$ & $3.20 \mathrm{E}-05$ & $8.65 \mathrm{E}-16$ & 1.33E-08 & $1.30 \mathrm{E}-08$ & $2.25 \mathrm{E}-08$ & 4.89E- 08 \\
\hline${ }^{233} \mathrm{U}$ & $2.86 E-02$ & $7.72 E-13$ & $5.99 \mathrm{E}-06$ & 2.18E-05 & $5.65 \mathrm{E}-06$ & $1.10 \mathrm{E}-05$ \\
\hline${ }^{238} \mathrm{Pu}$ & 3.26E-02 & $8.81 E-13$ & $5.95 E-06$ & $6.58 \mathrm{E}-06$ & $9.69 \mathrm{E}-06$ & $1.28 \mathrm{E}-05$ \\
\hline${ }^{239} \mathrm{Pu}$ & 3.02E-02 & $8.17 E-13$ & $6.77 \mathrm{E}-07$ & $9.40 E-07$ & $1.33 \mathrm{E}-06$ & $3.21 E-06$ \\
\hline${ }^{240} \mathrm{Pu}$ & $3.06 \mathrm{E}-02$ & $8.26 \mathrm{E}-13$ & $6.76 \mathrm{E}-07$ & 5.58E-07 & 1.11E-06 & $2.97 \mathrm{E}-06$ \\
\hline${ }^{241} \mathrm{Am}$ & $3.28 \mathrm{E}-02$ & $8.87 E-13$ & $3.73 E-06$ & $6.65 E-06$ & 1.07E-05 & $1.06 \mathrm{E}-05$ \\
\hline${ }^{24} \mathrm{Cm}$ & $3.44 \mathrm{E}-02$ & $9.29 E-13$ & 4.18E-05 & 3.25E-05 & 4.92E-05 & $1.02 E-04$ \\
\hline \multicolumn{3}{|l|}{ Total:(W/Kg) } & $5.27 \mathrm{E}-04$ & $4.76 \mathrm{E}-04$ & $7.45 E-04$ & 9:06E:04 \\
\hline Density & (Kg/L): & & 1.561 & 1.541 & 1.479 & 1.501 \\
\hline \multicolumn{3}{|c|}{ Total in 55 gal drum $(\mathrm{Kg})$ : } & 325 & 321 & 308 & 312 \\
\hline \multicolumn{3}{|c|}{ Total in 55 gal drum (Watt): } & 0.171 & 0.153 & 0.230 & 0.283 \\
\hline
\end{tabular}


Table 17 Summary of Relative Decay Heat in C1 and C2 Sludge

\begin{tabular}{|c|c|c|c|c|c|c|}
\hline Isotope & $\begin{array}{c}\text { "Q" value } \\
\text { (W/Ci) }\end{array}$ & $\begin{array}{l}\text { "Q" value } \\
\text { (W/Bq) }\end{array}$ & $\begin{array}{c}\text { C1-E } \\
\text { (\% Watt) }\end{array}$ & $\begin{array}{c}\text { C1-W } \\
\text { (\% Watt) }\end{array}$ & $\begin{array}{c}\text { C2-E } \\
\text { (\% Watt) } \\
\end{array}$ & $\begin{array}{c}C 2-W \\
(\% \text { Watt) }\end{array}$ \\
\hline${ }^{60} \mathrm{Co}$ & $1.54 E-02$ & 4.16E-13 & $3.40 \%$ & $1.84 \%$ & $2.63 \%$ & $2.94 \%$ \\
\hline${ }^{90} \mathrm{Sr}$ & $1.16 \mathrm{E}-03$ & $3.14 \mathrm{E}-14$ & $7.14 \%$ & $5.80 \%$ & $3.74 \%$ & $4.85 \%$ \\
\hline${ }^{90} \mathrm{Y}$ & 5.54E-03 & $1.50 \mathrm{E}-13$ & $34.10 \%$ & $27.69 \%$ & $17.88 \%$ & $23.14 \%$ \\
\hline${ }^{137} \mathrm{Cs}$ & $1.01 \mathrm{E}-03$ & $2.73 E-14$ & $2.38 \%$ & $4.02 \%$ & $3.37 \%$ & $2.59 \%$ \\
\hline${ }^{137 \mathrm{~m}} \mathrm{Ba}$ & $3.94 \mathrm{E}-03$ & $1.06 \mathrm{E}-13$ & $9.30 \%$ & $15.67 \%$ & $13.14 \%$ & $10.11 \%$ \\
\hline${ }^{152} \mathrm{Eu}$ & 7.65E-03 & $2.07 \mathrm{E}-13$ & $21.18 \%$ & $22.58 \%$ & $36.04 \%$ & $27.37 \%$ \\
\hline${ }^{154} \mathrm{Eu}$ & $9.08 \mathrm{E}-03$ & $2.45 E-13$ & $11.18 \%$ & $7.74 \%$ & $12.51 \%$ & $13.00 \%$ \\
\hline${ }^{155} \mathrm{Eu}$ & 7.59E-04 & $2.05 E-14$ & $0.15 \%$ & $0.16 \%$ & $0.26 \%$ & $0.22 \%$ \\
\hline${ }^{241} \mathrm{Pu}$ & $3.20 \mathrm{E}-05$ & 8.65E-16 & $0.00 \%$ & $0.00 \%$ & $0.00 \%$ & $0.01 \%$ \\
\hline \multicolumn{3}{|c|}{ Total beta heat (\%): } & $88.84 \%$ & $85.49 \%$ & $89.57 \%$ & $84.23 \%$ \\
\hline${ }^{233} \mathrm{U}$ & $2.86 \mathrm{E}-02$ & $7.72 \mathrm{E}-13$ & $1.14 \%$ & $4.58 \%$ & $0.76 \%$ & $1.22 \%$ \\
\hline${ }^{238} \mathrm{Pu}$ & $3.26 \mathrm{E}-02$ & 8.81E-13 & $1.13 \%$ & $1.38 \%$ & $1.30 \%$ & $1.41 \%$ \\
\hline${ }^{239} \mathrm{Pu}$ & 3.02E-02 & 8.17E-13 & $0.13 \%$ & $0.20 \%$ & $0.18 \%$ & $0.35 \%$ \\
\hline${ }^{240} \mathrm{Pu}$ & $3.06 \mathrm{E}-02$ & $8.26 \mathrm{E}-13$ & $0.13 \%$ & $0.12 \%$ & $0.15 \%$ & $0.33 \%$ \\
\hline${ }^{241} \mathrm{Am}$ & $3.28 \mathrm{E}-02$ & 8.87E-13 & $0.71 \%$ & $1.40 \%$ & $1.44 \%$ & $1.18 \%$ \\
\hline${ }^{244} \mathrm{Cm}$ & $3.44 \mathrm{E}-02$ & $9.29 E-13$ & $7.93 \%$ & $6.83 \%$ & $6.60 \%$ & $11.28 \%$ \\
\hline \multicolumn{3}{|c|}{ Total alpha heat $(\%)$ : } & $11.16 \%$ & $14.51 \%$ & $10.43 \%$ & $15.77 \%$ \\
\hline
\end{tabular}


Figure 8 Distribution of Beta Decay Heat in C1 and C2 Sludge

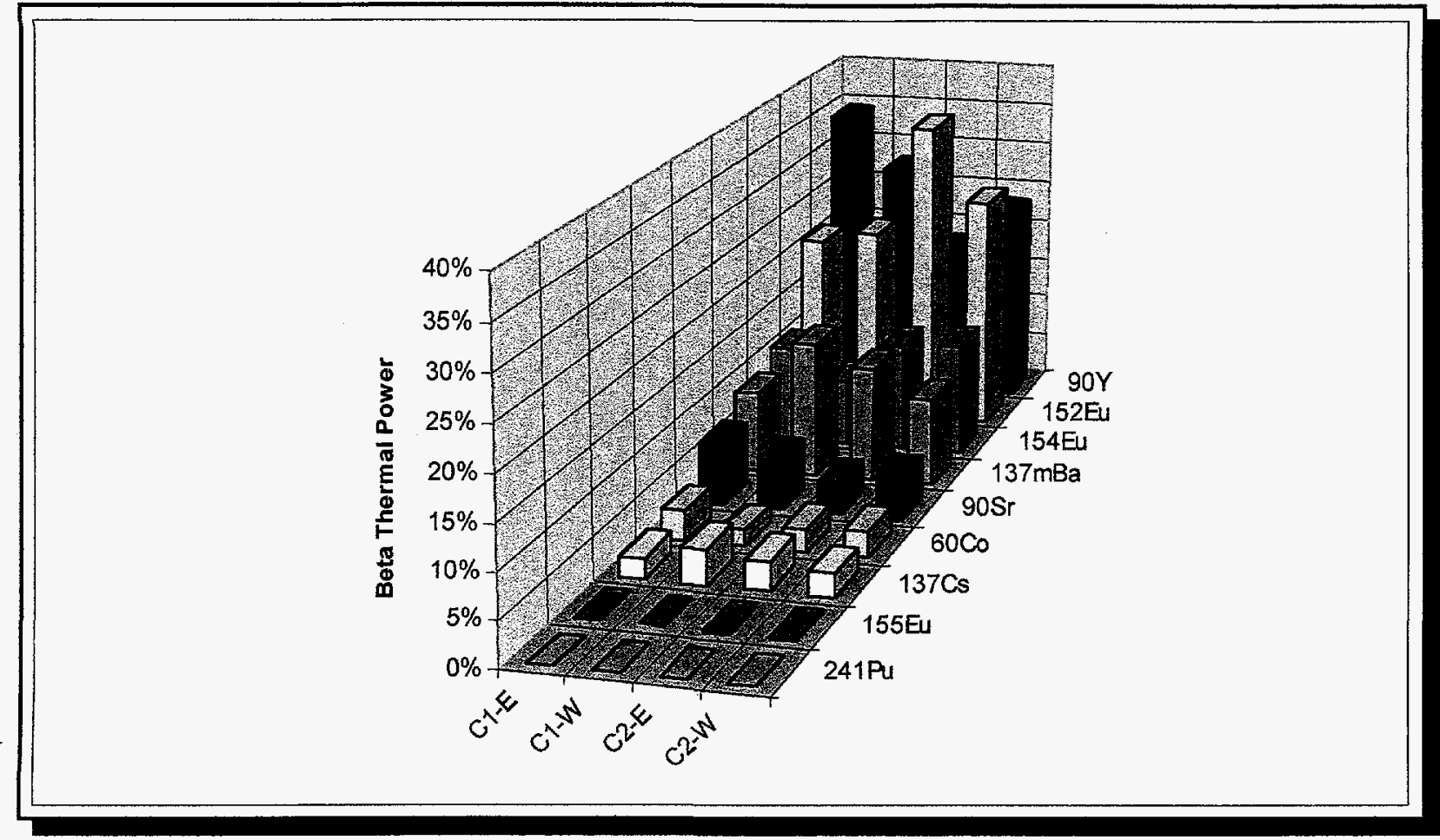

Figure 9 Distribution of Alpha Decay Heat in C1 and C2 Sludge

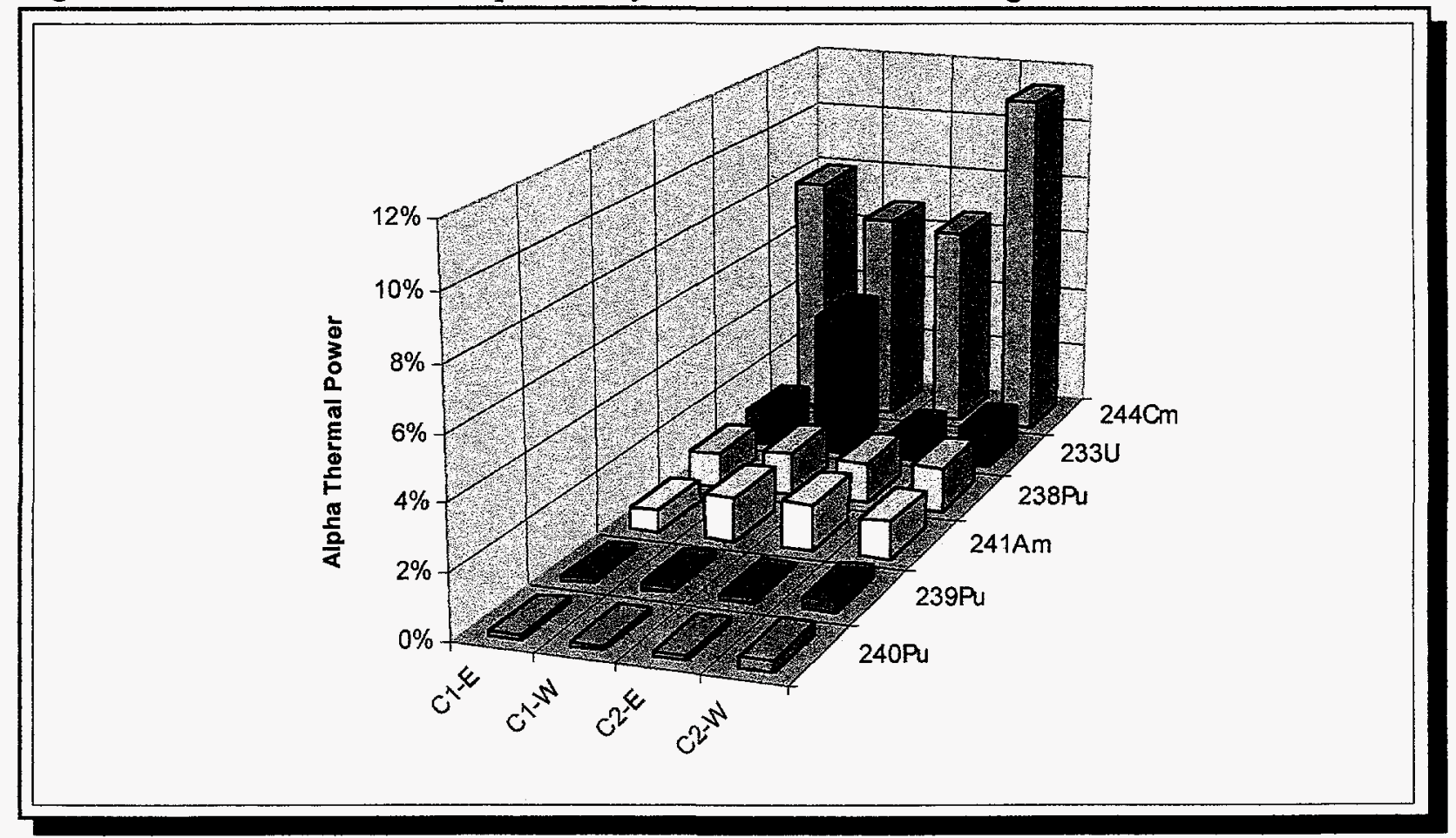




\subsection{Summary of Organic Analytical Results}

The organic target compound list (TCL) hits and the tentatively identified compounds (TIC) from the GC-MS, GC-FID, and GC-ECD analyses are listed in Table 18 for the $\mathrm{C} 1$ and $\mathrm{C} 2$ sludge samples. Table 19 also includes the regulatory limits based on the Universal Treatment Standards (UTS) from the Land Disposal Restrictions (LDR) regulations (40 CFR 268.48). The RCRA TCLP limits for organic compounds are listed in Table 19 and are reproduced for each corresponding RCRA compounds in parenthesis next to the compound name for quick reference in the liquid and sludge result tables. For the organic chemical characterization results the following reporting conventions are used:

\section{Reporting limits}

B

D

$\mathbf{E}$

$\mathbf{J}$

$\mathbf{U}$

TIC
The reporting limits are the concentrations above which the response of the instrument for the calibrated range of concentrations is linear.

Data qualifier meaning that the compound was also found in the accompanying laboratory blank sample.

Data qualifier meaning sample dilution was required.

Data qualifier indicating that the reported concentration of the compound exceeded the calibration range of the instrument.

Data qualifier meaning that the compound was estimated at a concentration below the reporting limit; also used to indicate that the concentrations for tentatively identified compounds (TICs) are estimates.

Data qualifier meaning compound was not detected or was below the method detection limits (MDL) and the MDL corrected for dilution was reported.

Tentatively identified compound. The identification is based upon mass spectral data only, and the quantitation is based upon the response factor of the nearest eluting internal standard. All TIC values are estimates and are flagged with the " $\mathrm{J}$ " qualifier. 


\section{Table 18 Analytical organic data for OHF sludge samples}

\begin{tabular}{|c|c|c|c|c|c|}
\hline \multirow{2}{*}{ Target Compound } & \multirow{2}{*}{$\begin{array}{c}\text { Reg. } \\
\text { Limit' } \\
\text { (mg/Kg) }\end{array}$} & \multicolumn{4}{|c|}{ Concentration in Sludge, $\mathrm{mg} / \mathrm{Kg}$} \\
\hline & & C1-East & C1-West & C2-East & C2-West \\
\hline \multicolumn{6}{|c|}{ Non-halogenated Volatile Organic Compounds (NH-VOA) } \\
\hline 67-64-1 Acetone & 160 & 10. U & 10. U & 10. U & 10. U \\
\hline $71-36-3 \quad$ Butanol & 2.6 & 10. U & 10. U & 18. J & 10. U \\
\hline 78-83-1 Isobutanol & 170 & 10. U & 10. U & 10. U & 10. U \\
\hline 67-56-1 Methanol & 15 & 10. U & 10. U & 10. U & 10. U \\
\hline $\begin{array}{ll}\text { 78-93-3 Methyl ethyl ketone }(4000) \\
\text { 2-Butanone }\end{array}$ & 36 & 10. U & 10. U & 10. U & 10. U \\
\hline $110-86-1$ Pyridine & 16 & 10. U & 10. U & 10. U & 10. U \\
\hline \multicolumn{6}{|l|}{ Volatile Organic Compounds (VOA) } \\
\hline 71-43-2 Benzene & 10 & $5.0 \mathrm{U}$ & $5.0 \mathrm{U}$ & $5.0 \mathrm{U}$ & $5.0 \mathrm{U}$ \\
\hline 75-25-2 Bromoform & 15 & $5.0 \mathrm{U}$ & $5.0 \mathrm{U}$ & $5.0 \mathrm{U}$ & $5.0 \mathrm{U}$ \\
\hline 75-15-0 Carbon disulfide & 96 & $5.0 \mathrm{U}$ & $5.0 \mathrm{U}$ & $5.0 \mathrm{U}$ & $5.0 \mathrm{U}$ \\
\hline 56-23-5 Carbon tetrachloride $\quad(10)$ & 6 & $5.0 \mathrm{U}$ & $5.0 \mathrm{U}$ & $5.0 \mathrm{U}$ & $5.0 \mathrm{U}$ \\
\hline 108-90-7 Chlorobenzene & 6 & $5.0 \mathrm{U}$ & $5.0 \mathrm{U}$ & $5.0 \mathrm{U}$ & $5.0 \mathrm{U}$ \\
\hline 67-66-3 Chloroform & 6 & $5.0 \mathrm{U}$ & $5.0 \mathrm{U}$ & $5.0 \mathrm{U}$ & $5.0 \mathrm{U}$ \\
\hline 95-50-1 1,2-Dichlorobenzene & 6 & $5.0 \mathrm{U}$ & $5.0 \mathrm{U}$ & $5.0 \mathrm{U}$ & $5.0 \mathrm{U}$ \\
\hline 106-46-7 1,4-Dichlorobenzene (150) & 6 & $5.0 \mathrm{U}$ & $5.0 \mathrm{U}$ & $5.0 \mathrm{U}$ & $5.0 \mathrm{U}$ \\
\hline 107-06-2 1,2-Dichloroethane $\quad(10)$ & 6 & $5.0 \mathrm{U}$ & $5.0 \mathrm{U}$ & $5.0 \mathrm{U}$ & $5.0 \mathrm{U}$ \\
\hline 75-35-4 1,1-Dichloroethylene & 6 & $5.0 \mathrm{U}$ & $5.0 \mathrm{U}$ & $5.0 \mathrm{U}$ & $5.0 \mathrm{U}$ \\
\hline 100-41-4 Ethyl benzene & 10 & $5.0 \mathrm{U}$ & $5.0 \mathrm{U}$ & $5.0 \mathrm{U}$ & $5.0 \mathrm{U}$ \\
\hline 60-29-7 Ethyl ether & 160 & $5.0 \mathrm{U}$ & $5.0 \mathrm{U}$ & $5.0 \mathrm{U}$ & $5.0 \mathrm{U}$ \\
\hline 75-09-2 Methylene Chloride & 30 & $5.0 \mathrm{U}$ & $5.0 \mathrm{U}$ & $5.0 \mathrm{U}$ & $5.0 \mathrm{U}$ \\
\hline 79-34-5 1,1,2,2-Tetrachloroethane & 6 & $5.0 \mathrm{U}$ & $5.0 \mathrm{U}$ & $5.0 \mathrm{U}$ & $5.0 \mathrm{U}$ \\
\hline 127-18-4, Tetrachloroethylene (14) & 6 & $5.0 \mathrm{U}$ & $5.0 \mathrm{U}$ & $5.0 \mathrm{U}$ & $5.0 \mathrm{U}$ \\
\hline 108-88-3 Toluene & 10 & $5.0 \mathrm{U}$ & $5.0 \mathrm{U}$ & $5.0 \mathrm{U}$ & $5.0 \mathrm{U}$ \\
\hline 71-55-6 1,1,1-Trichloroethane & 6 & $5.0 \mathrm{U}$ & $5.0 \mathrm{U}$ & $5.0 \mathrm{U}$ & $5.0 \mathrm{U}$ \\
\hline 79-00-5 1,1,2-Trichloroethane & 6 & $5.0 \mathrm{U}$ & $5.0 \mathrm{U}$ & $5.0 \mathrm{U}$ & $5.0 \mathrm{U}$ \\
\hline 79-01-6 Trichloroethylene & 6 & $5.0 \mathrm{U}$ & $5.0 \mathrm{U}$ & $5.0 \mathrm{U}$ & $5.0 \mathrm{U}$ \\
\hline 75-69-4 Trichlorofluoromethane & 30 & $5.0 \mathrm{U}$ & $5.0 \mathrm{U}$ & $5.0 \mathrm{U}$ & $5.0 \mathrm{U}$ \\
\hline $\begin{array}{r}\text { 76-13-1 1,1,2-Trichloro-1,2,2- } \\
\text { trifluoroethane }\end{array}$ & 30 & $5.0 \mathrm{U}$ & $5.0 \mathrm{U}$ & $5.0 \mathrm{U}$ & $5.0 \mathrm{U}$ \\
\hline 75-01-4 Vinyl Chloride & 6 & $5.0 \mathrm{U}$ & $5.0 \mathrm{U}$ & $5.0 \mathrm{U}$ & $5.0 \mathrm{U}$ \\
\hline
\end{tabular}




\begin{tabular}{|c|c|c|c|c|c|}
\hline \multirow{2}{*}{ Target Compound } & \multirow{2}{*}{$\begin{array}{c}\text { Reg. } \\
\text { Limit }^{2} \\
\text { (mg/Kg) }\end{array}$} & \multicolumn{4}{|c|}{ Concentration in Sludge, $\mathrm{mg} / \mathrm{Kg}$} \\
\hline & & C1-East & C1-West & C2-East & C2-West \\
\hline 1330-20-7 m\&p-Xylene & 30 & $5.0 \mathrm{U}$ & $5.0 \mathrm{U}$ & $5.0 \mathrm{U}$ & $5.0 \mathrm{U}$ \\
\hline 95-47-6 o-Xylene & 30 & $5.0 \mathrm{U}$ & $5.0 \mathrm{U}$ & $5.0 \mathrm{U}$ & $5.0 \mathrm{U}$ \\
\hline \multicolumn{6}{|c|}{ Tentatively Identified Volatile Organic Compounds (uncalibrated) } \\
\hline 135-01-3 Benzene, 1,2-diethyl- & - & - & $19 \mathrm{~J}$ & $7 \mathrm{~J}$ & - \\
\hline 141-93-5 Benzene, 1,3-diethyl- & - & - & $130 \mathrm{~J}$ & $110 \mathrm{~J}$ & $32 \mathrm{~J}$ \\
\hline 105-05-5 Benzene, 1,4-diethyl- & - & - & $100 \mathrm{~J}$ & $41 \mathrm{~J}$ & $25 \mathrm{~J}$ \\
\hline 62238-12-4 Decane, 2,3,6-trimethyl- & - & - & - & - & $81 \mathrm{~J}$ \\
\hline 112-40-3 Dodecane & $\cdot$ & - & $73 \mathrm{~J}$ & $63 \mathrm{~J}$ & $180 \mathrm{~J}$ \\
\hline $\begin{array}{l}\text { 1667-01-2 Ethanone, } 1-(2,4,6- \\
\text { trimethylphenyl) }\end{array}$ & - & - & - & $28 \mathrm{~J}$ & $10 \mathrm{~J}$ \\
\hline $1120-21-4$ Undecane & $\cdot$ & - & $68 \mathrm{~J}$ & $12 J$ & $34 \mathrm{~J}$ \\
\hline Unknown Hydrocarbon & - & - & $363 \mathrm{~J}(13)$ & - & $58 \mathrm{~J}(6)$ \\
\hline Unknown & - & $58 \mathrm{~J}(1)^{\mathrm{b}}$ & $39 \mathrm{~J}(2)^{b}$ & $39 J(2)^{b}$ & $48 \mathrm{~J}(1)^{\mathrm{b}}$ \\
\hline \multicolumn{6}{|l|}{ Semivolatile Organic Compounds (SVOA) } \\
\hline 51-28-5 2,4-Dinitrophenol & 160 & $25 \mathrm{U}$ & $25 \mathrm{U}$ & $25 \mathrm{U}$ & $25 \mathrm{U}$ \\
\hline 121-14-2 2,4-Dinitrotoluene & 140 & $1.5 \mathrm{U}$ & $1.5 \mathrm{U}$ & $1.5 \mathrm{U}$ & $1.5 \mathrm{U}$ \\
\hline 118-74-1 Hexachlorobenzene (2.6) & 10 & $1.5 \mathrm{U}$ & $1.5 \mathrm{U}$ & $1.5 \mathrm{U}$ & $1.5 U$ \\
\hline 67-72-1 Hexachloroethane & 30 & $25 \mathrm{U}$ & $25 \mathrm{U}$ & $25 \mathrm{U}$ & $25 \mathrm{U}$ \\
\hline 95-48-7 2-Methyl Phenol $\quad(4000)$ & 5.6 & $25 \mathrm{U}$ & $25 \mathrm{U}$ & $25 \mathrm{U}$ & $25 \mathrm{U}$ \\
\hline 106-44-5 4-Methyl Phenol $\quad(4000)$ & 5.6 & $25 U$ & $25 \mathrm{U}$ & $25 \mathrm{U}$ & $25 U$ \\
\hline 98-95-3 Nitrobenzene & 14 & $25 \mathrm{U}$ & $25 \mathrm{U}$ & $25 \mathrm{U}$ & $25 \mathrm{U}$ \\
\hline 87-86-5 Pentachlorophenol (2000) & 7.4 & $25 U$ & $25 \mathrm{U}$ & $-25 \mathrm{U}$ & $25 \mathrm{U}$ \\
\hline \multicolumn{6}{|c|}{ Tentatively Identified Semivolatile Organic Compounds (uncalibrated) } \\
\hline $\begin{array}{l}04478-10-9 \text { Benzene, 2-bromo-4-methyl- } \\
1-(1-\end{array}$ & - & - & $6 \mathrm{~J}$ & & - \\
\hline 4537-15-9 Benzene, (1-butylheptyl)- & & & & & $7 \mathrm{~J}$ \\
\hline 141-93-5 Benzene, -diethyl & - & - & $52 \mathrm{~J}$ & $3 \mathrm{~J}$ & - \\
\hline 2400-00-2 Benzene, (1-ethyldecyl)- & - & $2 \mathrm{~J}$ & - & & - \\
\hline 4534-52-5 Benzene, (1-ethylundecyl)- & - & $2 \mathrm{~J}$ & - & & - \\
\hline 4536-88-3 Benzene, (1-methyldecyl)- & - & $3 \mathrm{~J}$ & - & & $11 \mathrm{~J}$ \\
\hline $\begin{array}{l}\text { 2719-61-1 Benzene, (1- } \\
\text { methylundecy1). }\end{array}$ & - & $4 \mathrm{~J}$ & - & & $10 \mathrm{~J}$ \\
\hline 2719-62-2 Benzene, (1-pentylheptyl)- & & $2 \mathrm{~J}$ & - & & $8 \mathrm{~J}$ \\
\hline $\begin{array}{l}\text { 55044-09-2 Benzene, 1, 1'-(oxydi-2,1- } \\
\text { ethane) }\end{array}$ & - & - & $6 \mathrm{~J}$ & - & - \\
\hline
\end{tabular}




\begin{tabular}{|c|c|c|c|c|c|}
\hline \multirow{2}{*}{ Target Compound } & \multirow{2}{*}{$\begin{array}{c}\text { Reg. } \\
\text { Limit }^{2} \\
\text { (mg/Kg) }\end{array}$} & \multicolumn{4}{|c|}{ Concentration in Sludge, $\mathrm{mg} / \mathrm{Kg}$} \\
\hline & & C1-East & C1-West & C2-East & C2-West \\
\hline 117-81-7 Bis(2-ethylhexyl)phthalate & - & $2 \mathrm{~J}$ & & - & - \\
\hline $\begin{array}{l}\text { 4291-79-6 Cyclohexane, 1-methyl-2- } \\
\text { propyl- }\end{array}$ & - & - & - & $2 \mathrm{~J}$ & - \\
\hline 112-40-3 Dodecane & - & - & $11 \mathrm{~J}$ & $6 \mathrm{~J}$ & $22 \mathrm{~J}$ \\
\hline $\begin{array}{ll}120-40-1 & \text { Dodecanamide, N,N-bis(2- } \\
\text { hydroxyl }\end{array}$ & - & $2 \mathrm{~J}$ & - & - & - \\
\hline 112-95-8 Eicosane & - & - & $3 J$ & - & - \\
\hline 57-10-3 Hexadecanoic acid & - & $3 \mathbf{J}$ & - & - & - \\
\hline 104-76-7 1-Hexanol,2-ethyl- & - & $4 \mathrm{~J}$ & - & $10 \mathrm{~J}$ & $24 \mathrm{~J}$ \\
\hline 6280-57-5 Formamide, N,N-dioctyl- & - & - & - & $6 \mathrm{~J}$ & $\cdot$ \\
\hline 112-05-0 Nanoic acid & - & $7 \mathrm{~J}$ & - & - & - \\
\hline 1116-76-3 1-Octanamine, N,N-dioctyl- & - & - & - & - & $10 \mathrm{~J}$ \\
\hline 1120-48-5 1-Octanamine, n-octyl- & - & - & - & - & $10 \mathrm{~J}$ \\
\hline $\begin{array}{ll}\text { 78-42-2 } & \text { Phosphoric acid, tris(2- } \\
\text { ethylhexyl) }\end{array}$ & - & $5 \mathrm{~J}$ & $3 J$ & $43 \mathrm{~J}$ & $38 \mathrm{~J}$ \\
\hline 629-59-4 Tetradecane & - & $4 \mathrm{~J}$ & $16 \mathrm{~J}$ & $17 \mathrm{~J}$ & $28 \mathrm{~J}$ \\
\hline 629-50-5 Tridecane & - & $3 \mathbf{J}$ & $15 \mathrm{~J}$ & $14 \mathrm{~J}$ & $28 \mathrm{~J}$ \\
\hline 126-73-8 Tributylphosphate (TBP) & - & $3 \mathbf{J}$ & $15 \mathrm{~J}$ & - & $20 \mathrm{~J}$ \\
\hline 1120-21-4 Undecane & - & - & $8 \mathrm{~J}$ & - & - \\
\hline Unknown Hydrocarbon & - & - & $4 \mathrm{~J}(1)^{\mathrm{b}}$ & - & - \\
\hline Unknown & - & $11 \mathrm{~J}(3)^{6}$ & $58 \mathrm{~J}(8)^{\mathrm{b}}$ & $47 \mathrm{~J}(11)^{\mathrm{b}}$ & $89 \mathrm{~J}(7)^{\mathrm{b}}$ \\
\hline
\end{tabular}

${ }^{a}$ Regulatory limits based on Universal Treatment Standards (Nonwastewater standard) from 40 CFR $\$ 268.48$.

${ }^{b}$ Number of compounds grouped together listed in parenthesis. 
Table 19 RCRA TCLP limits for target organic compounds

\begin{tabular}{||l|l|c|c||}
\hline \hline CAS No. & \multicolumn{1}{|c|}{ Target Compound } & $\begin{array}{c}\text { TCLP Limit } \\
(\mathbf{m g} / \mathbf{L})\end{array}$ & $\begin{array}{c}\text { Sludge Limit }^{\mathrm{b}} \\
\text { (mg/Kg) }\end{array}$ \\
\hline \hline $71-43-2$ & Benzene & 0.5 & 10.0 \\
\hline $56-23-5$ & Carbon tetrachloride & 0.5 & 10.0 \\
\hline $108-90-7$ & Chlorobenzene & 100.0 & 2000.0 \\
\hline $67-66-3$ & Chloroform & 6.0 & 120.0 \\
\hline $95-48-7$ & o-Cresol & 200.0 & 4000.0 \\
\hline $108-39-4$ & m-Cresol & 200.0 & 4000.0 \\
\hline $106-44-5$ & p-Cresol & 200.0 & 4000.0 \\
\hline $51-28-5$ & 2,4-Dinitrophenol & 10.0 & 200.0 \\
\hline $106-46-7$ & 1,4-Dichlorobenzene & 7.5 & 150.0 \\
\hline $107-06-2$ & 1,2-Dichloroethane & 0.5 & 10.0 \\
\hline $75-35-4$ & 1,1-Dichloroethylene & 0.7 & 14.0 \\
\hline $121-14-2$ & 2,4-Dinitrotoluene & 0.13 & 2.6 \\
\hline $118-74-1$ & Hexachlorobenzene & 0.13 & 2.6 \\
\hline $87-68-3$ & Hexachloro-1,3-butadiene & 0.5 & 10.0 \\
\hline $67-72-1$ & Hexachloroethane & 3.0 & 60.0 \\
\hline $78-93-3$ & Methyl ethyl ketone & 200.0 & 4000.0 \\
\hline $98-95-3$ & Nitrobenzene & 2.0 & 40.0 \\
\hline $87-86-5$ & Pentachlorophenol & 100.0 & 2000.0 \\
\hline $110-86-1$ & Pyridine & 5.0 & 100.0 \\
\hline $127-18-4$ & Tetrachloroethylene & 0.7 & 14.0 \\
\hline $79-01-6$ & Trichloroethylene & 0.5 & 10.0 \\
\hline $95-95-4$ & $2,4,5-$ Trichlorophenol & 400.0 & 8000.0 \\
\hline $88-06-2$ & $2,4,6-$ Trichlorophenol & 2.0 & 40.0 \\
\hline $75-01-4$ & Vinyl chloride & 0.2 & \\
\hline
\end{tabular}

${ }^{2}$ Regulatory limits taken from SW-846, Chapter 7, Table 7-1 (also see 40 CFR \$261.24).

b The sludge limit is the concentration required in a solid sample to exceed the limit after a TCLP leach. 


\subsection{Discussion of Organic Analysis}

The concentration of non-polar organic compounds identified in the $\mathrm{C} 1$ and $\mathrm{C} 2$ sludge samples were limited to a few hundred $\mathrm{mg} / \mathrm{Kg}$ observed in the sludge samples. The organic compounds identified consistent with bi-products from the Purex and other actinide separations used by past nuclear processing operations within ORNL

The identification of the total organic content in radioactive waste tanks continues to be a problem for this laboratory and others throughout the DOE sites. Similar to past experiences, the sum of the identified organic compounds is considerably lower than what the total organic carbon content would indicate. The partial balance of the total organic carbon content was most likely due to the presence of high molecular weight polar compounds which would not have been detected by the gas and liquid chromatographic methods used for the organic measurements. Also, most forms of biological organic matter, including decay products from vegetation and microorganisms, would not be detected by the conventional measurement techniques used for waste characterization. The biological organic material would contribute to the final concentration reported from the total organic carbon measurements.

\subsection{Regulatory Concerns due to Organic Compounds in Waste Tank Sludge}

The regulatory definition states that the waste exhibits the characteristic of toxicity (RCRA) if the TCLP extract from a sub-sample of the waste contains any of the compounds listed in Table 18 at a concentration greater than or equal to the respective values given in the table. If the waste contains $<0.5 \%$ filterable solids, the liquid (supernatant for this project) itself, after filtering, is considered to be the extract for the purpose of analysis. None of the $\mathrm{C} 1$ and $\mathrm{C} 2$ sludge samples exceeded the TCLP leachate limits listed in Table 18.

The regulatory limits listed in Table 18 are requirements from the Land Disposal Restrictions (LDR) program (40 CFR $\$ 268.41$ ). These limits are provided for information only and can be found under Universal Treatment Standards (UTS) in 40 CFR $\$ 268.48$, Table UTS. Although some of the organic compounds in the liquid phase exceed the UTS limits, this should not be a problem for the 
disposal of radioactive waste. In general, the regulatory driver for both TRU and non-TRU radioactive waste is the WIPP Target Compound List which includes the RCRA compounds, some common organic solvents, plus a few additional organic compounds of interest to EPA and New Mexico state regulators. The WIPP waste acceptance criteria also requires the concentration of any PCBs present in the waste be documented. The waste acceptance criteria for the Nevada Test Site (NTS), which only accepts non-TRU waste, only requires that the generator demonstrate that the waste is not RCRA and does not contain PCBs over $50 \mathrm{ppm}$. The NTS requirements are similar to most other private and state operated disposal sites for non-TRU radioactive waste. Therefore, if the generator uses the WIPP target compound list for guidance and includes PCB data, all the organic results required for disposal of most radioactive waste should be covered. Most generators of radioactive waste use process knowledge to exclude organic complexing agents or chelators from the waste data package. 


\subsection{Summary of Rheometry Measurements}

\subsection{Rheometry Tests}

The rheometry data presented here was collected for the purpose of obtaining a simple and rapid estimate of flow properties for the $\mathrm{C} 2$ sludge at various concentrations of suspended solids. There was not enough sludge available fro the $\mathrm{Cl}$ tank to perform these tests. The sludge samples used for these tests were heterogeneous and contained coarse particles, both of these sample characteristics would degrade the rheometry measurements. The interpretation of the data presented in this section is left to the user of this document. No data reduction was performed nor were any mathematical corrections or curve fitting/smoothing parameters applied to the data. All of the data presented here is on file at the RMAL and is available for further study and analysis for those readers who desire more information.

Viscosity data was collected for the C2-East sludge samples using a Rotovisco RV30 Searle type rotational CR (controlled rate) rheometer, available from Gebrueder $\mathrm{HAAKE} \mathrm{GmbH,} \mathrm{Karlsruhe} \mathrm{or}$ HAAKE (USA). The Searle type measuring system is comprised of a calibrated spring whose deflection is proportional to the torque and converted by a transducer to an electronic signal. The system is close to friction free and provides an instantaneous response. Viscosity curves were generated using an immersion system comprised of an immersion tube and a modified HAAKE MV DIN rotor. The modified rotor has a smaller diameter than the original $(36.4 \mathrm{~mm}$ vs. $38.7 \mathrm{~mm})$ and a height of $58.08 \mathrm{~mm}$.

All tests were conducted in a hot cell. The sensors and measuring system were located in the cell and connected to a control unit outside of the cell. A personal computer connected to the control unit was used to run the rheometer software, set test parameters, and collect data. Samples for viscosity measurements were kept at a constant temperature during the tests utilizing a plexiglass bath located in the cell with cooling coils that were supplied from a temperature controlled water bath located outside of the cell. 


\subsection{Viscosity Curves}

The core sample from C2-East sludge was mixed and diluted with tank supernatant at an approximate ratios to yield $5 \%$ and $10 \%$ suspended solids. From this sludge dilution, an aliquot was removed for total solids and undissolved solids determination. Subsequently, the viscosity were measured over a range of increasing shear rates as indicated on the viscosity curves on Fig. 10 and Fig. 11. The ramp time was three minutes, and each sample was held at its highest shear rate for two minutes with no change in viscosity observed (no shear thickening). The temperature throughout the tests was maintained at $25^{\circ} \mathrm{C} \pm 1{ }^{\circ} \mathrm{C}$. The tests were performed using the HAAKE immersion sensor system. The system is comprised of a hollow immersion tube with an inner diameter of 42 $\mathrm{mm}$ and a modified cylindrical MV DIN rotor with a diameter of $36.8 \mathrm{~mm}$ that is placed within the tube. This leaves an annular distance of $5.2 \mathrm{~mm}$ between the rotor and tube wall for the sample to flow during the test. Without the modification to the rotor this annular distance would have only been $3.3 \mathrm{~mm}$. The annular distance was enlarged to minimize the bias due to the enactment of large particles within the sludges on the flow measurements.

Prior to the start of all tests, the samples were stabilized at a temperature of $25^{\circ} \mathrm{C} \pm 1{ }^{\circ} \mathrm{C}$ with a circulating water bath. During the temperature stabilization process each sample was stirred to suspend the slurry for the test. Typically this process took approximately $10 \mathrm{~min}$. to complete. Once at temperature, the sensor was lowered into the sample and the measurements were begun. The samples were stirred throughout the tests to ensure that the particles were maintained in suspension.

The fluctuations noted during measurements are believed to be due to a combination of the samples' heterogeneous matrix and the presence of some larger particles in the samples. Also, the sensitive measurement scale used (mPa-s) for the $y$-axis on the viscosity curves would amplify those fluctuations. 
Figure 10 Apparent Viscosity for C2-East with 3.1\% Suspended Solids

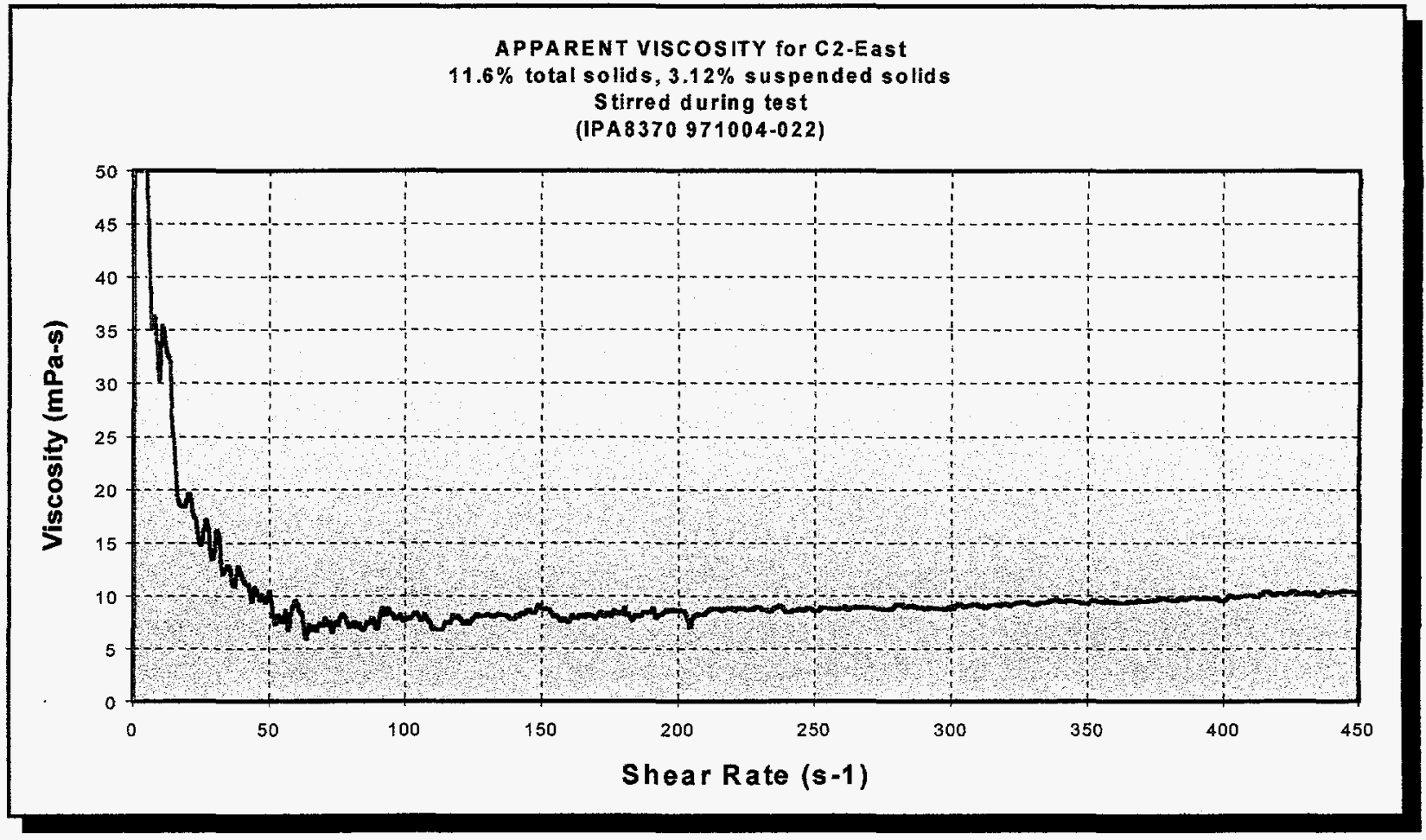

Figure 11 Apparent Viscosity for C2-East with $6.8 \%$ Suspended Solids

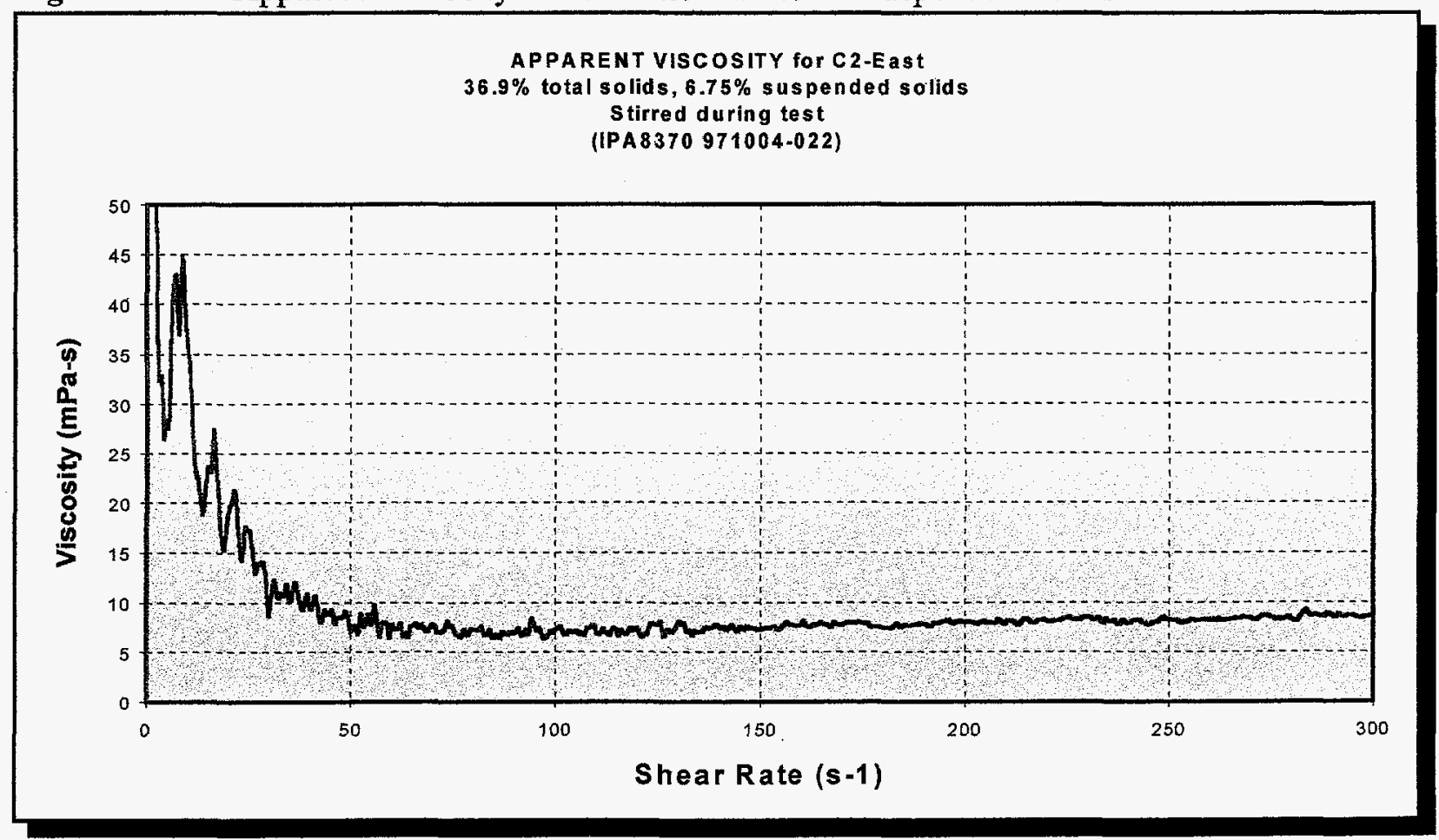




\subsection{Sedimentation Rates}

Settling characteristics are an important consideration in removal of the sludge from the waste tanks. The settling rate of undissolved solids in a solution is determined by the terminal velocities of the various particles. The terminal velocity can be calculated according to the following equation (Stoke's Law):

$$
V_{s}=\frac{g r^{2}\left(\rho_{1}-\rho_{2}\right)}{18 \mu}
$$

where: $\quad r=$ the radius of the spherical particle

$\rho_{1}=$ the density of the sphere

$\rho_{2}=$ the density of the medium

$\mu=$ fluid viscosity.

$\mathrm{g}=$ gravitational constant

Settling tests were conducted on portions of the $\mathrm{C} 1$ and $\mathrm{C} 2$ sludge samples using the following simplified procedure:

1. From the already settled sample, the supernatant layer was decanted leaving behind the wet sludge.

2. A portion of this sludge was introduced into a graduated cylinder $(100 \mathrm{~mL}$ capacity).

3. A portion of supernatant from the same tank was added to the sludge so the volumes were at approximately a 1:1 ratio in the graduated cylinder.

4. The cylinder was capped and inverted several times to suspend the solids.

5. All cylinders were positioned upright to start the settling test. The first two hours of settling was continuously recorded with a camcorder. For the next several days recordings were taken at various intervals during the working day.

6. At the end of the test period, the video record was used to plot the settling rate for each sample. Measurements were recorded in volume units according to the graduation of the cylinder at which the interface between the mostly sludge layer and the mostly liquid layer lie. 
This method is a crude but effective substitute for predicting the net effect of what would happen should a pump break or flow of the slurry be in some way forced to stop during the removal/transfer process. Visual observations of particles in a clear solution ceases at approximately 50 to 65 microns. Although the ambient temperature fluctuated some during the test it was considered to be a small enough change to not be a factor. It is also important to note that the graduated cylinders stood vertical during the entire time of the settling, since any angle introduced to the column would change (increase) the settling rate due to collection of the particles on the side of the column.

According to Stoke's law the largest particles will fall out of suspension the fastest, and of course the most dense particles will fall quicker than those which are less dense. This law assumes that first, the particles are spherical in shape, which will usually not be the case, and second, a solid particle would not allow flow of molecules and other particles through itself. In this experiment there is not enough information to apply Stoke's law to predict a true settling curve. However, the application of Stoke's Law using the available data across the same times required in the settling tests produces distances of travel that are consistent with the physical setup of the experiment.

Figure 12 illustrates the laboratory setup for the sedimentation experiments performed on the $\mathrm{C} 1$ and C2 sludge samples. As shown in Figure 12 the starting interface height between the supernatant and the sludge would be $0 \%$ solids suspended. The relative percent solids suspended plotted on the sedimentation curves is defined as follows:

$$
\% \text { settled sludge }=\left[1-\left(H_{t}-H_{x}\right) /\left(H_{t}-H_{s}\right)\right] \times 100 \%
$$

Figures 13 and 14 show the relative settling rates for the $\mathrm{C} 1$ and $\mathrm{C} 2$ sludge samples versus the time in hours following the mixing to suspend the solids. It should be noted that at the end of the settling period neither of the sludge samples settled down to the original starting volume $\left(\mathrm{H}_{\mathrm{s}}\right)$. After several days (approx. 120 hours) the sludge from C1-East and C2-East were $70 \%$ and $40 \%$ settled, respectively, relative to the starting sludge volumes. 
Figure 12 Illustration of Parameters used for Sedimentation Rate Experiments

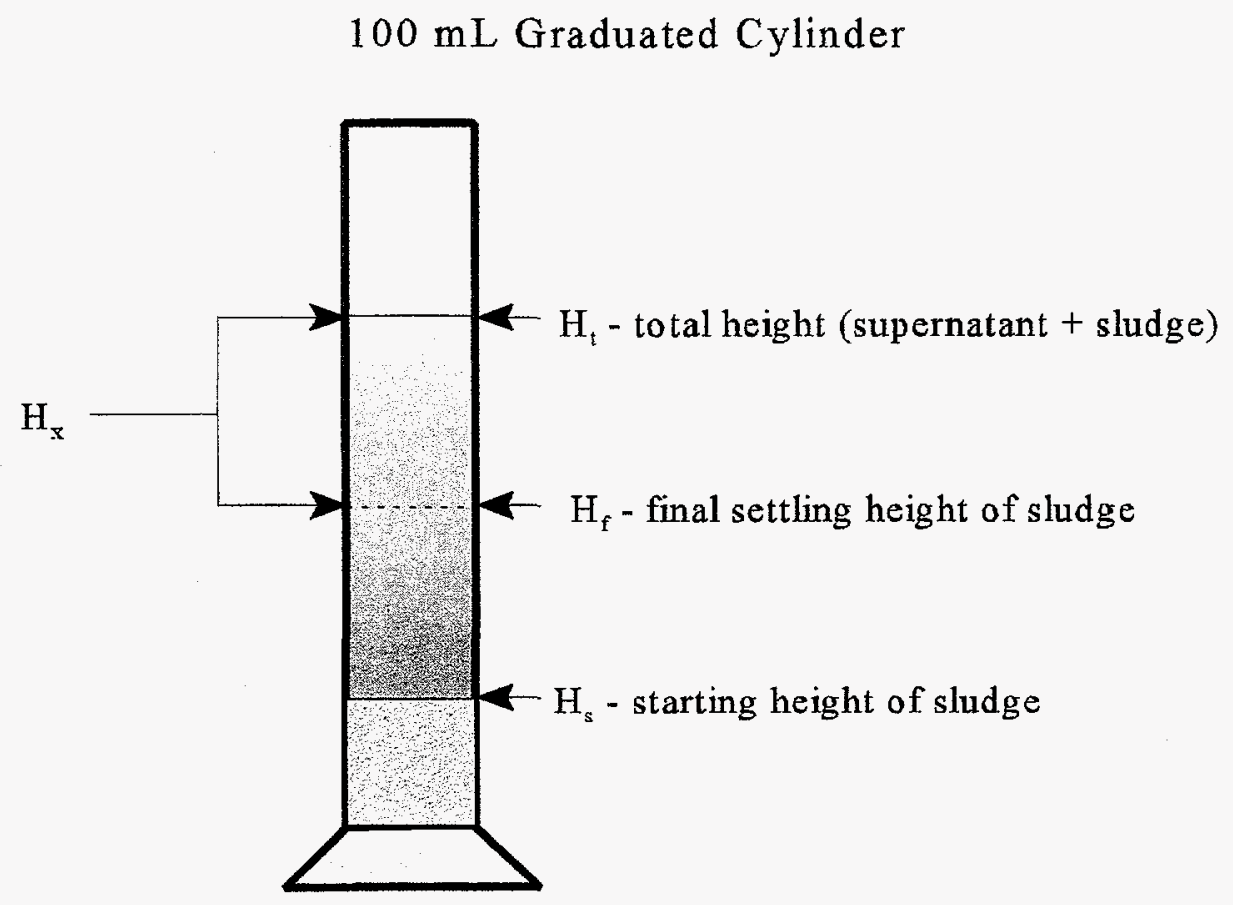


Figure 13 Sedimentation Rates for $\mathrm{C} 1$ and C2 Sludge During the First Five Hours

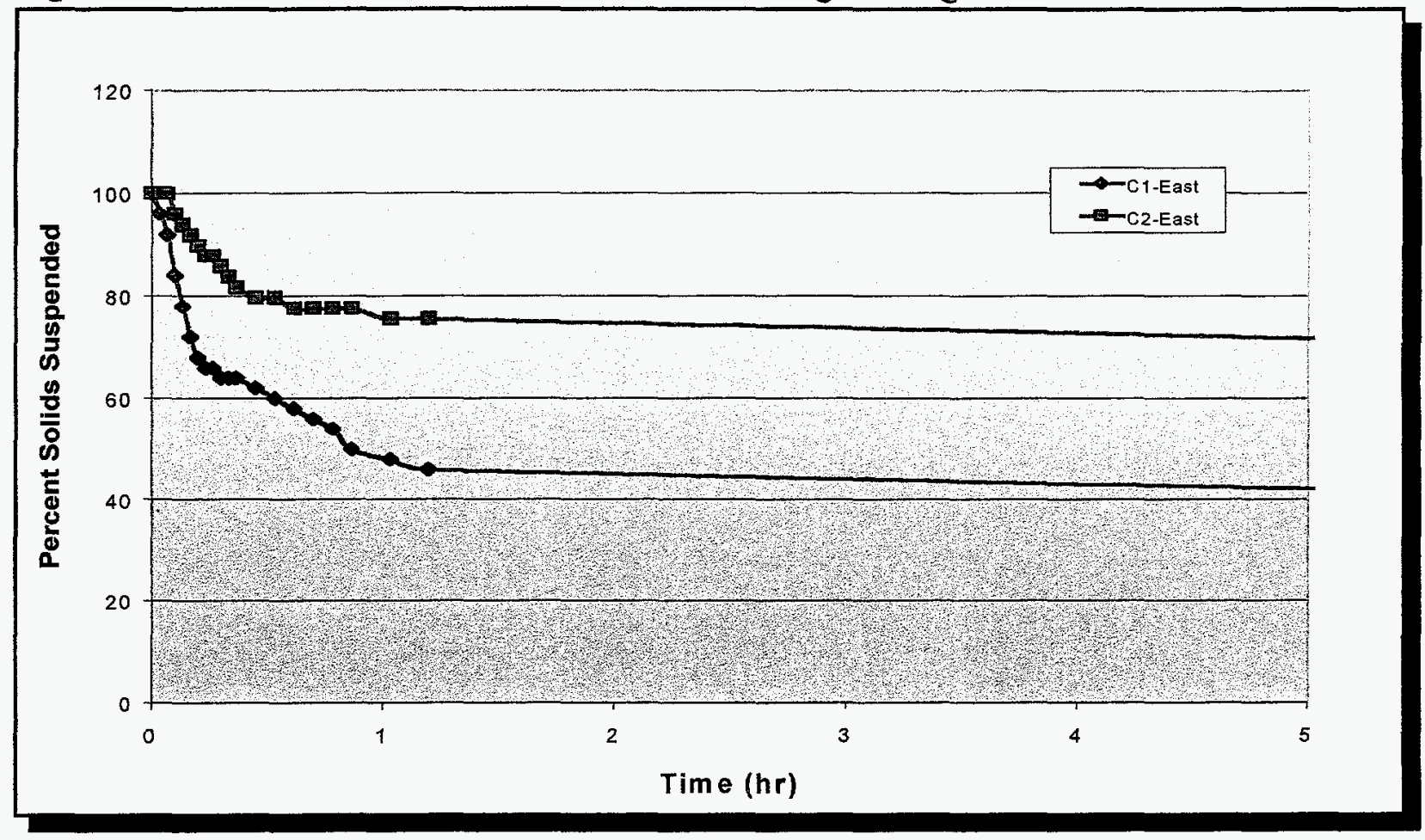

Figure 14 Sedimentation Rates for C1 and C2 Sludge for Several Days

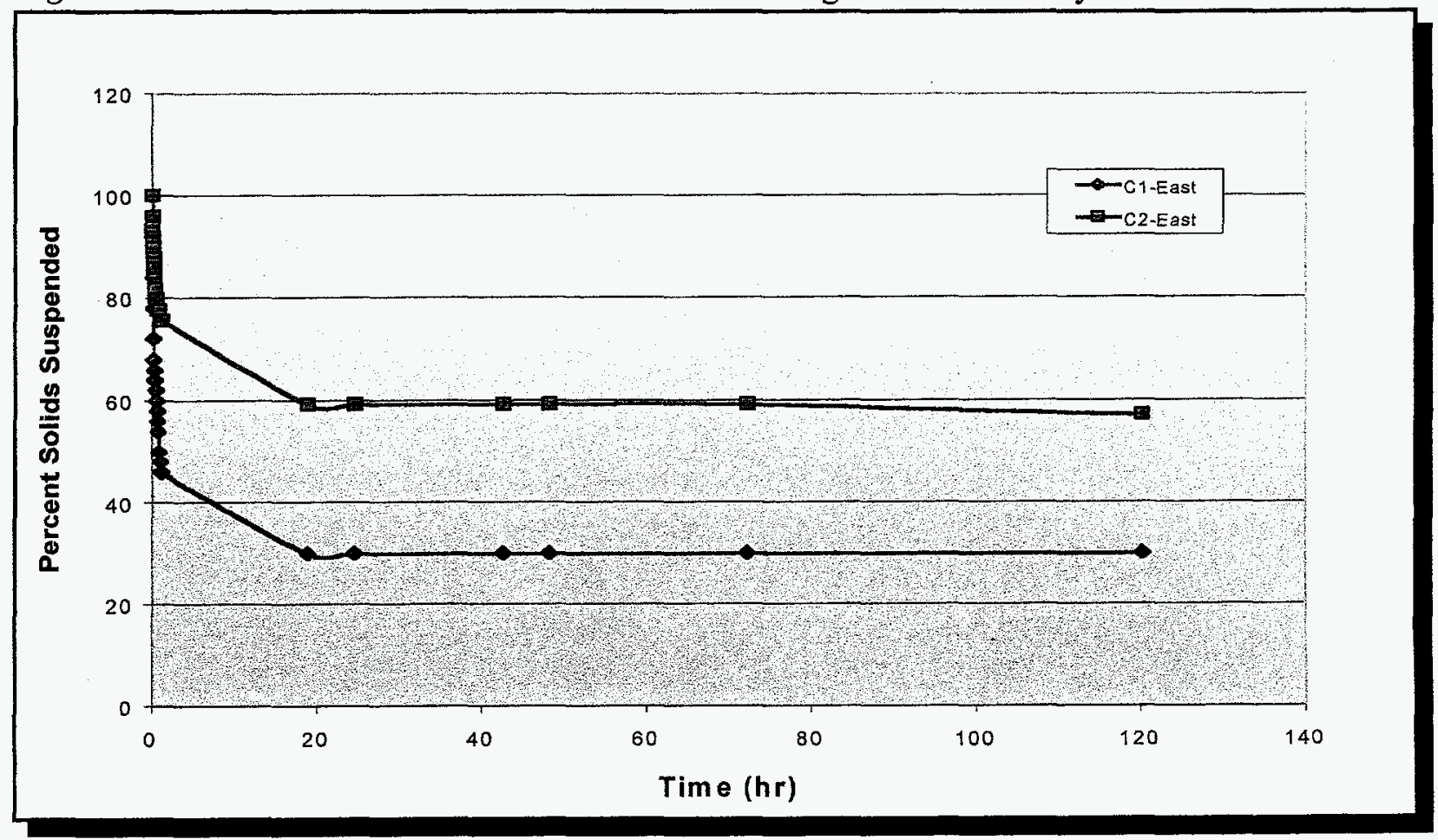


.

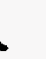

, 


\section{REFERENCES}

1. J. M. Keller, J. M. Giaquinto, and A. M. Meeks, Characterization of the MVST Waste Tanks Located at ORNL, ORNL/TM-13357, December 1996.

2. J. M. Keller, J. M. Giaquinto, and A. M. Meeks, Characterization of the BVEST Waste Tanks Located at ORNL, ORNL/TM-13358, January 1997.

3. J. M. Giaquinto, J. M. Keller, and T. P. Mills, Miscellaneous Data for the 1996-1997 Sampling and Analysis Campaigns of the MVST, BVEST, and OHF Tank Complexes, ORNL/TM-13455, July 1997.

4. F. J. Peretz, B. R. Clark, C. B. Scott, and J. B. Berry, Characterization of Low-Level Liquid Wastes at the Oak Ridge National Laboratory, ORNL/TM-10218, December 1986.

5. M. B. Sears, J. L. Botts, R. N. Ceo, J.J. Ferrada, W. H. Griest, J. M. Keller, and R. L. Schenley, Sampling and Analysis of Radioactive Liquid Wastes and Sludges in the Melton Valley and Evaporator Facility Storage Tanks at ORNL, ORNL/TM-11652, September 1990.

6. J. M. Keller, J. M. Giaquinto, and W. H. Griest, Characterization of Selected Waste Tanks from the Active LLLW System, ORNL/TM-13248, August 1996.

7. M. B. Sears, Results of Sampling the Contents of the Liquid Low-Level Waste Evaporator Feed Tank W-22, ORNL/TM-13234, September 1996.

8. C. K. Bayne, S. M. DePaoli, J. R. DeVore, D. J. Downing, J. M. Keller, Statistical Description of Liquid Low-Level Waste System Transuranic Wastes at Oak Ridge National Laboratory, Oak Ridge, Tennessee, ORNL/TM-13351, December 1996.

9. J. M. Keller, J. M. Giaquinto, and A. M. Meeks, Characterization of the Old Hydrofracture Facility (OHF) Waste Tanks Located at ORNL, ORNL/TM-13394, April 1997.

10. C. K. Bayne, J. R. DeVore, A. B. Walker, Statistical Description of Liquid Low-Level Waste System Supernatant Liquids at Oak Ridge National Laboratory, Oak Ridge, Tennessee, ORNL/TM-13351 Addendum 1, October 1997.

11. T. D. Hylton, Sampling and Analysis Plan for the C-1 and C-2 Tanks, ORNL/M-6156, October 1997.

12. J. W. Moore, Lockheed Martin Energy Systems, Central Engineering, Oak Ridge, TN, personal communication to J. M. Keller, October 28, 1997. 
13. U. S. Environmental Protection Agency, Test Methods for Evaluating Solid Waste, SW-846, 3rd ed, Office of Solid Waste and Emergency Response, Washington, D.C., November 1986; Update I, July 1992; and Final Update II, September 1994.

14. J. M. Giaquinto, A. M. Essling, and J. M. Keller, Comparison of SW-846 Method 3051 and SW-846 Method 7471A for the Preparation of Solid Waste Samples for Mercury Determination, ORNL/TM-13236, July 1996.

15. Transuranic Waste Characterization Quality Assurance Program Plan, Rev. 0, CAO-941010, April 30, 1995.

16. Radioactive Materials Analysis Laboratory - Oak Ridge National Laboratory (RMALORNL) Quality Assurance Project Plan (QAPjP) for the Transuranic Waste Characterization Program (TWCP), Rev. 1, QAP-X-CASD/RML-002, January 1996.

17. Radioactive Materials Analysis Laboratory Quality Assurance Plan for the Characterization of Radioactive Waste, QAP-X-CASD/RML-001, Rev. 1, June 1996

18. Waste Acceptance Criteria for the Waste Isolation Pilot Plant, WIPP-DOE-069, Rev. 5.0, April 1996.

19. Table B.1. Characteristics of Important Radionuclides, Integrated Database (IDB) Report, DOE/RW-0006, Rev. 11, September 1995. 


\section{APPENDIX A}

\section{Radioactive Materials Analytical Laboratory}

QC Acceptance Criteria for Radioactive Liquid/Solid Waste Samples

\begin{tabular}{|c|c|c|c|c|}
\hline Analysis & $\begin{array}{l}\text { Method (s) } \\
\text { CASD-AM- }\end{array}$ & $\begin{array}{l}\text { Quality Control } \\
\text { Check } \\
\text { (per batch) }\end{array}$ & $\begin{array}{c}\text { SW-846 } \\
\text { Acceptance } \\
\text { Criteria } \\
(\% D, \% R, R P D)^{\mathrm{e}}\end{array}$ & $\begin{array}{c}\text { RMAL } \\
\text { Acceptance } \\
\text { Criteria } \\
(\% \mathbf{\%}, \% \mathbf{R}, \mathbf{R P D})^{\mathrm{e}}\end{array}$ \\
\hline $\begin{array}{l}\text { Metals by ICP-AES } \\
\text { (inductively } \\
\text { coupled plasma } \\
\text { atomic emission } \\
\text { spectroscopy) }\end{array}$ & SW846-6010A & $\begin{array}{l}\text { high standard } \\
\text { calibration verifications (ICV \& CCV) } \\
\text { calibration blank \& checks (ICB \& CCB) } \\
\text { method blank (sample prep) } \\
\text { matrix spike } \\
\text { matrix spike duplicate or sample cuplicate } \\
\text { laboratory control sample (sample prep) } \\
\text { serial dilution (if interference suspected) }^{\mathrm{c}} \\
\text { post digestion spike }\end{array}$ & $\begin{array}{c} \pm 5 \% \mathrm{D} \\
\pm 10 \% \mathrm{D} \\
3 \times \mathrm{IDL} \\
\varangle \times \mathrm{IDL} \\
\pm 20 \% \mathrm{D} \\
\pm 20 \mathrm{RPD} \\
\text { none specified } \\
\pm 10 \% \mathrm{R} \\
\pm 20 \% \mathrm{D}\end{array}$ & $\begin{array}{c} \pm 5 \% \mathrm{D} \\
=10 \% \mathrm{D} \\
<\times \mathrm{IDL} \\
<3 \times \mathrm{IDL} \\
\pm 25 \% \mathrm{D} \text { (liq.), }=30 \% \mathrm{D} \text { (solid) } \\
\pm 20 \mathrm{RPD} \text { (liq.), } \pm 30 \mathrm{RPD} \text { (solid) } \\
\pm 20 \% \mathrm{D} \\
\pm 10 \% \mathrm{R} \\
\pm 25 \% \mathrm{D} \text { (liq.), } \pm 30 \% \mathrm{D} \text { (solid) }\end{array}$ \\
\hline $\begin{array}{l}\text { Metals by ICP-MS } \\
\text { (inductively } \\
\text { coupled plasma- } \\
\text { mass spectrometry, } \\
\text { fully quantitative } \\
\text { method) }\end{array}$ & SW846-6020 & $\begin{array}{l}\text { calibration verifications (ICV \& CCV)' } \\
\text { calibration blank \& blank checks (CCB) } \\
\text { method blank (sample prep) } \\
\text { matrix spike } \\
\text { matrix spike duplicate or sample duplicate } \\
\text { laboratory control sample (sample prep) } \\
\text { internal standard } \\
\text { post digestion spike }\end{array}$ & $\begin{array}{l} \pm 10 \% \mathrm{D} \\
<\times \text { IDL } \\
\text { none specified } \\
\text { none specified } \\
\pm 20 \mathrm{RPD} \\
\text { none specified } \\
30-120 \% \mathrm{R} \\
\pm 10 \% \mathrm{D}\end{array}$ & $\begin{array}{c} \pm 10 \% \mathrm{D} \\
<3 \times \mathrm{IDL} \\
<10 \times \mathrm{IDL} \\
\pm 25 \% \mathrm{D} \text { (liq.), } \pm 30 \% \mathrm{D} \text { (solid) } \\
\pm 20 \mathrm{RPD} \text { (liq.), } \pm 30 \mathrm{RPD} \text { (solid) } \\
\pm 20 \% \mathrm{D} \\
\pm 30 \% \mathrm{D} \\
\pm 20 \% \mathrm{D}\end{array}$ \\
\hline $\begin{array}{l}\text { Metals by GFAA } \\
\text { (graphite furmace } \\
\text { atomic absorption) }\end{array}$ & SW846-7000A & $\begin{array}{l}\text { high standard } \\
\text { calibration verifications (ICV \& CCV) } \\
\text { method blank (sample prep) } \\
\text { matrix spike } \\
\text { matrix spike duplicate } \\
\text { laboratory control sample (sample prep) } \\
\text { serial dilution (if interference suspected) } \\
\text { post digestion spike }\end{array}$ & $\begin{array}{c}\text { not required } \\
\pm 10 \% \mathrm{D}(\mathrm{ICV}), \pm 20 \% \mathrm{D}(\mathrm{CCV}) \\
\text { none specified } \\
\text { none specified } \\
\text { none specified } \\
\text { none specified } \\
\pm 10 \% \mathrm{R} \\
\pm 15 \% \mathrm{D}\end{array}$ & $\begin{array}{c} \pm 5 \% \mathrm{D} \\
\pm 10 \% \mathrm{D} \text { (ICV), } \pm 20 \% \mathrm{D} \text { (CCV) } \\
<3 \times \mathrm{IDL} \\
\pm 25 \% \mathrm{D} \text { (liq.), } \pm 30 \% \mathrm{D} \text { (solid) } \\
\pm 20 \mathrm{RPD} \text { (liq.), } \pm 30 \mathrm{RPD} \text { (solid) } \\
\pm 25 \% \mathrm{D} \\
\pm 10 \% \mathrm{R} \\
\pm 25 \% \mathrm{D} \text { (liq.) }, \pm 30 \% \mathrm{D} \text { (solid) }\end{array}$ \\
\hline $\begin{array}{l}\text { Mercury by CVAA } \\
\text { (cold vapor atomic } \\
\text { absorption) }\end{array}$ & $\begin{array}{l}\text { SW846-7471A } \\
\text { SW846-7470 }\end{array}$ & $\begin{array}{l}\text { instrument blank } \\
\text { calibration verification (ICV \& CCV)' } \\
\text { method blank (sample prep) } \\
\text { laboratory control sample (sample prep) } \\
\text { matrix spike } \\
\text { matrix spike duplicate or sample duplicate } \\
\text { post digestion spike }\end{array}$ & $\begin{array}{l}\text { none specified } \\
\text { none specified } \\
\text { none specified } \\
\text { none specified } \\
\text { none specified } \\
\text { none specified } \\
\text { none specified }\end{array}$ & $\begin{array}{c}<5 \times \mathrm{IDL} \\
\pm 10 \% \mathrm{D} \\
<5 \times \mathrm{IDL} \\
\pm 25 \% \mathrm{D} \\
\pm 25 \% \mathrm{D} \text { (liq.), } \pm 30 \% \mathrm{D} \text { (solid) } \\
\pm 20 \mathrm{RPD} \text { (liq.), } \pm 30 \mathrm{RPD} \text { (solid) } \\
\pm 25 \% \mathrm{D} \text { (liq.), } \pm 30 \% \mathrm{D} \text { (solid) }\end{array}$ \\
\hline $\begin{array}{l}\text { Carbon (total } \\
\text { organic carbon, } \\
\text { total carbon, total } \\
\text { inorganic carbon) }\end{array}$ & SW846-9060 & $\begin{array}{l}\text { instrument blank } \\
\text { calibration verification (ICV \& CCV)" } \\
\text { matrix spike } \\
\text { matrix spike duplicate }\end{array}$ & $\begin{array}{l}\text { none specified } \\
\text { none specified } \\
\text { none specified } \\
\text { none specified }\end{array}$ & $\begin{array}{c}<3 \times \mathrm{IDL} \\
\pm 10 \% \mathrm{D} \text { (lCV.), } \pm 20 \% \mathrm{D} \text { (CCV) } \\
\pm 25 \% \mathrm{D} \text { (liq.), } \pm 30 \% \mathrm{D} \text { (solid) } \\
\pm 20 \mathrm{RPD} \text { (liq.), } \pm 30 \mathrm{RPD} \text { (solid) }\end{array}$ \\
\hline $\begin{array}{l}\text { Anions by Ion } \\
\text { Chromatography } \\
\text { (IC) }\end{array}$ & SW846-9056 & $\begin{array}{l}\text { calibration verification (ICV \& CCV) } \\
\text { matrix spike } \\
\text { sample duplicate }\end{array}$ & $\begin{array}{c}=10 \% \mathrm{D}(\mathrm{ICV}), \pm 5 \% \mathrm{D}(\mathrm{CCV}) \\
\text { none specified } \\
\text { none specified }\end{array}$ & $\begin{array}{c} \pm 10 \% \mathrm{D}(\mathrm{ICV}), \pm 15 \% \mathrm{D}(\mathrm{CCV}) \\
\pm 25 \% \mathrm{D} \\
\pm 20 \mathrm{RPD}\end{array}$ \\
\hline $\mathrm{pH}$ measurement & $\begin{array}{l}\text { SW846-9040A } \\
\text { SW846-9045B }\end{array}$ & $\begin{array}{l}\text { check standard } \\
\text { sample duplicate }\end{array}$ & $\begin{array}{l}\text { none specified } \\
\text { none specified }\end{array}$ & $\begin{array}{l} \pm 10 \% D \\
\pm 20 \% \mathrm{D}\end{array}$ \\
\hline $\begin{array}{l}\text { Total and dissolved } \\
\text { solids (TS \& TDS) }\end{array}$ & $\begin{array}{l}\text { EPA600-160.2 } \\
\text { EPA600-160.3 }\end{array}$ & $\begin{array}{l}\text { sample duplicate } \\
\text { check standard }\end{array}$ & $\begin{array}{l}\text { none specified } \\
\text { none specified }\end{array}$ & $\begin{array}{c} \pm 10 \mathrm{mg} / 10 \mathrm{~mL} \text { sample } \\
\pm 10 \% \mathrm{D}\end{array}$ \\
\hline $\begin{array}{l}\text { Carbonate and } \\
\text { bicarbonate titration }\end{array}$ & AC-MM-1 003105 & $\begin{array}{l}\text { sample duplicate } \\
\text { check standard }\end{array}$ & $\begin{array}{l}\text { none specified } \\
\text { none specified }\end{array}$ & $\begin{array}{l} \pm 20 \mathrm{RPD} \\
\pm 20 \% \mathrm{D}\end{array}$ \\
\hline Gross alpharbeta & $\begin{array}{l}\text { EPA-900.0 } \\
\text { RML-RA02 } \\
\text { RML-RA12 }\end{array}$ & $\begin{array}{l}\text { background check } \\
\text { calibration verification } \\
\text { method blank (optional) } \\
\text { sample duplicate } \\
\text { matrix spike }\end{array}$ & $\begin{array}{l}\text { none specified } \\
\text { none specified } \\
\text { none specified } \\
\text { none specified } \\
\text { none specified }\end{array}$ & $\begin{array}{c}\text { < 3sigma daily change } \\
\pm 10 \% \mathrm{D} \\
\text { evaluated for contamination } \\
\pm 25 \mathrm{RPD} \text { (liq), } \pm 30 \mathrm{RPD} \text { (solid) } \\
\pm 25 \% \mathrm{D} \text { (liq.) \& } \pm 30 \% \mathrm{D} \text { (solid) }\end{array}$ \\
\hline $\begin{array}{l}\text { Nuclides by gamma } \\
\text { spectrometry }\end{array}$ & $E P A-901.1$ & $\begin{array}{l}\text { background check } \\
\text { calibration verification } \\
\text { sample duplicate }\end{array}$ & $\begin{array}{l}\text { none specified } \\
\text { none specified } \\
\text { none specified }\end{array}$ & $\begin{array}{c}<3 \text { sigma daily change } \\
\pm 10 \% \mathrm{D} \\
\pm 25 \% \mathrm{D} \text { (liq.) \& } \pm 30 \% \mathrm{D} \text { (solid) }\end{array}$ \\
\hline
\end{tabular}




\begin{tabular}{|c|c|c|c|c|}
\hline Analysis & $\begin{array}{l}\text { Method (s) } \\
\text { CASD-AM- }\end{array}$ & $\begin{array}{c}\text { Quality Control } \\
\text { Check } \\
\text { (per batch) }\end{array}$ & $\begin{array}{c}\text { SW-846 } \\
\text { Acceptance } \\
\text { Criteria } \\
(\% \mathbf{D}, \% \mathbf{R}, \mathbf{R P D})^{\mathbf{e}}\end{array}$ & $\begin{array}{c}\text { RMAL } \\
\text { Acceptance } \\
\text { Criteria } \\
(\% \mathbf{D}, \% \mathbf{R}, \mathbf{R P D})^{\mathbf{e}}\end{array}$ \\
\hline ST-90 determination & $\begin{array}{l}\text { RML-RA13 } \\
\text { EPA-905.0 }\end{array}$ & $\begin{array}{l}\text { method blank (optional) } \\
\text { laboratory control sample } \\
\text { matrix spike } \\
\text { matrix spike duplicate or sample duplicate } \\
\text { associated instrument } Q C\end{array}$ & $\begin{array}{l}\text { none specified } \\
\text { none specified } \\
\text { none specified } \\
\text { none specified } \\
\text { none specified }\end{array}$ & $\begin{array}{l}\text { evaluated for contamination } \\
\qquad 20 \% \mathrm{D} \\
=25 \% \mathrm{D} \text { (liq.) } 8 \pm 30 \% \mathrm{D} \text { (solid) } \\
\pm 25 \mathrm{RPD} \text { (liq.), } \pm 30 \mathrm{RPD} \text { (solid) } \\
\text { see gross aipha/beta criteria }\end{array}$ \\
\hline $\begin{array}{l}\mathrm{T}-99 \\
\text { determination }\end{array}$ & $\begin{array}{l}\text { DOE Compendium } \\
\text { RP550 } \\
\text { RML-RA05 }\end{array}$ & $\begin{array}{l}\text { method blank (optional) } \\
\text { laboratory control sample } \\
\text { matrix spike } \\
\text { matrix spike or sample duplicate } \\
\text { associated instrument QC }\end{array}$ & $\begin{array}{l}\text { none specified } \\
\text { none specified } \\
\text { none specified } \\
\text { none specified } \\
\text { none specified }\end{array}$ & $\begin{array}{c}<3 \times \text { IDL } \\
20 \% \mathrm{D} \\
\pm 25 \% \mathrm{D} \text { (liq.) \& } \pm 30 \% \mathrm{D} \text { (solid) } \\
\pm 25 \mathrm{RPD} \text { (liq.), } \pm 30 \mathrm{RPD} \text { (solid) } \\
\text { see ICP-MS criteria }\end{array}$ \\
\hline $\mathrm{H}-3$ determination & EPA-906.0 & $\begin{array}{l}\text { method blank (optional) } \\
\text { laboratory control sample } \\
\text { matrix spike } \\
\text { matrix spike duplicate or sample duplicate } \\
\text { associated instrument } Q C\end{array}$ & $\begin{array}{l}\text { none specified } \\
\text { none specified } \\
\text { none specified } \\
\text { none specified } \\
\text { none specified }\end{array}$ & $\begin{array}{l}\text { evaluated for contamination } \\
\qquad 20 \% \mathrm{D} \\
\pm 25 \% \mathrm{D} \text { (liq.) } \& \pm 30 \% \mathrm{D} \text { (solid) } \\
\pm 25 \mathrm{RPD} \text { (liq.), } \pm 30 \mathrm{RPD} \text { (solid) } \\
\text { see gross alpha/beta criteria }\end{array}$ \\
\hline $\mathrm{Cm}-244$ & RML-RA06 & $\begin{array}{l}\text { method blank (optional) } \\
\text { laboratory control sample } \\
\text { matrix spike } \\
\text { matrix spike duplicate or sample duplicate } \\
\text { associated instrument } Q C\end{array}$ & $\begin{array}{l}\text { none specified } \\
\text { none specified } \\
\text { none specified } \\
\text { none specified } \\
\text { none specified }\end{array}$ & $\begin{array}{l}\text { evaluated for contamination } \\
\qquad 20 \% \mathrm{D} \\
\pm 25 \% \mathrm{D} \text { (liq.) } \& \pm 30 \% \mathrm{D} \text { (solid) } \\
\pm 25 \mathrm{RPD} \text { (liq.), } \pm 30 \mathrm{RPD} \text { (solid) } \\
\text { see gross alpha/beta criteria }\end{array}$ \\
\hline $\mathrm{Put}-238,239 / 240$ & $\begin{array}{l}\text { RML,RA11 } \\
\text { RML-RA08 }\end{array}$ & $\begin{array}{l}\text { method blank (optional) } \\
\text { laboratory control sample } \\
\text { matrix spike } \\
\text { matrix spike duplicate or sample duplicate } \\
\text { associated instrument } Q C\end{array}$ & $\begin{array}{l}\text { none specified } \\
\text { none specified } \\
\text { none specified } \\
\text { none specified } \\
\text { none specified }\end{array}$ & $\begin{array}{l}\text { evaluated for contamination } 8 \\
20 \% \mathrm{D} \\
\pm 25 \% \mathrm{D} \text { (liq.) \& } \pm 30 \% \mathrm{D} \text { (solid) } \\
\pm 25 \mathrm{RPD} \text { (liq.), } \pm 30 \mathrm{RPD} \text { (solid) } \\
\text { see gross alpha/beta criteria }\end{array}$ \\
\hline$U-233 / 234$ & RML-RA10 & $\begin{array}{l}\text { method blank (optional) } \\
\text { laboratory control sample } \\
\text { matrix spike } \\
\text { matrix spike duplicate or sample duplicate } \\
\text { associated instrument QC }\end{array}$ & $\begin{array}{l}\text { none specified } \\
\text { none specified } \\
\text { none specified } \\
\text { none specified } \\
\text { none specified }\end{array}$ & $\begin{array}{l}\text { evaluated for costemineting } \\
\qquad 20 \% \mathrm{D} \\
\pm 25 \% \mathrm{D} \text { (liq.) \& } \pm 30 \% \mathrm{D} \text { (solid) } \\
\pm 25 \mathrm{RPD} \text { (liq.), } \pm 30 \mathrm{RPD} \text { (solid) } \\
\text { see gross alpha/beta criteria }\end{array}$ \\
\hline Th Determination & $\begin{array}{l}\text { EPA-901.1 } \\
\text { RML-RA09 }\end{array}$ & $\begin{array}{l}\text { method blank (optional) } \\
\text { laboratory control sample } \\
\text { matrix spike } \\
\text { matrix spike duplicate or sample duplicate } \\
\text { associated instrument QC }\end{array}$ & $\begin{array}{l}\text { none specified } \\
\text { none specified } \\
\text { none specified } \\
\text { none specified } \\
\text { none specified }\end{array}$ & $\begin{array}{l}\text { evaluated for contamination } \\
\qquad 20 \% \mathrm{D} \\
\pm 25 \% \mathrm{D} \text { (liq.) \& } \pm 30 \% \mathrm{D} \text { (solid) } \\
\pm 25 \mathrm{RPD} \text { (liq.), } \pm 30 \mathrm{RPD} \text { (solid) } \\
\text { see gamma spectrometry criteria }\end{array}$ \\
\hline $\begin{array}{l}\text { PCBs } \\
\text { (polychlorinated- } \\
\text { biphenyls) }\end{array}$ & SW846-8080 & $\begin{array}{l}\text { calibration verification (ICV \& CCV)" } \\
\text { method blank (sample prep) } \\
\text { surrogate standard } \\
\text { matrix spike } \\
\text { matrix spike duplicate } \\
\text { sample duplicate } \\
\text { laboratory control sample (sample prep) }\end{array}$ & $\begin{array}{l}\text { refer to method } 8080 \\
\text { none specified } \\
\text { none specified } \\
\text { none specified } \\
\text { none specified } \\
\text { none specified } \\
\text { none specified }\end{array}$ & $\begin{array}{l}\text { to be specified" } \\
\text { < regulatory limit (2ppm) } \\
\quad \pm 50-150 \% R \\
\pm 50-150 \% R \\
\quad \neq 50-150 \% R \\
\text { to be specified } \\
\text { to be specified }\end{array}$ \\
\hline Volatile organics & SW846-8260 & $\begin{array}{l}\text { calibration verification (ICV \& CCV) } \\
\text { method blank (sample prep) } \\
\text { surrogate standard } \\
\text { matrix spike } \\
\text { matrix spike duplicate } \\
\text { sample duplicate } \\
\text { laboratory control sample (sample prep) }\end{array}$ & see SW846 8260, Sept. '86 & 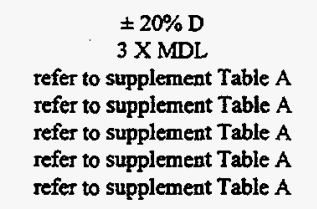 \\
\hline $\begin{array}{l}\text { Nonhalogenated } \\
\text { volatile organics }\end{array}$ & SW846-8015 & $\begin{array}{l}\text { calibration verification (ICV \& CCV) } \\
\text { method blank (sample prep) } \\
\text { surrogate standard } \\
\text { matrix spike } \\
\text { matrix spike duplicate } \\
\text { sample duplicate } \\
\text { laboratory control sample (sample prep) }\end{array}$ & $\begin{array}{c}\text { see SW846-8015, Sept. '86 } \\
" \\
" \\
"\end{array}$ & $\begin{array}{l}\quad \pm 15 \% \mathrm{D} \\
\quad 3 \mathrm{X} \mathrm{MDL} \\
\text { refer to supplement Table B } \\
\text { refer to supplement Table B } \\
\text { refer to supplement Table B } \\
\text { refer to supplement Table B } \\
\text { refer to supplement Table B }\end{array}$ \\
\hline $\begin{array}{l}\text { Semivolatile } \\
\text { organics }\end{array}$ & SW846-8270 & $\begin{array}{l}\text { calibration verification }(\mathrm{ICV} \& \mathrm{CCV})^{\mathrm{a}} \\
\text { method blank (sample prep) } \\
\text { surrogate standard } \\
\text { matrix spike } \\
\text { matrix spike duplicate } \\
\text { sample duplicate } \\
\text { laboratory control sample (sample prep) }\end{array}$ & $\begin{array}{c}\text { see SW846-8270, Sept. ' } 86 \\
" \\
" \\
" \\
"\end{array}$ & $\begin{array}{l}\qquad \pm 20 \% \mathrm{D} \\
\quad 3 \mathrm{XMDL} \\
\text { refer to supplement Table C } \\
\text { refer to supplement Table C } \\
\text { refer to supplement Table } \mathrm{C} \\
\text { refer to supplement Table } \mathrm{C} \\
\text { refer to supplement Table C }\end{array}$ \\
\hline
\end{tabular}


Initial calibration verification (ICV) is typically performed at the beginning of a run to check the calibration and must be independent of the calibration standards. The continuing calibration verification (CCV) must also be independent of the calibration standards, but may be the same standard as the ICV. The CCV is typically analyzed every 10 samples and at the end of the run for metals analysis or every 12 samples for organic analysis.

b The calibration blank is an instrument blank used in the calibration to initially determine the blank value and therefore used as blank subtraction. The continuing calibration blank (CCB) is also an instrument blank which is analyzed every 10 samples and at the end of the run, but is not used in blank subtraction, but only to monitor instrument contamination.

Method blanks and laboratory control samples are only required if a sample preparation is performed before analysis. Sample preparation does not include dilutions or transfers to containers.

d Post digestion spikes are not necessary if the pre-digestion spike is in control. If this control does not meet the QC acceptance criteria, the post digestion spike should be performed.

e

Acceptance criteria:

$\% \mathrm{D}=\%$ deviation from true value

$\% \mathrm{R}=\%$ recovery of true value

$\mathrm{RPD}=$ relative percent difference between two compared values

f Method blanks for radiochemical analysis are used to monitor cross contamination. However, due to the levels of radioactivity present in samples at the RMAL, the effect of contamination may be insignificant in most cases. Therefore, the requirement to analyze a method blank for radiochemical analysis is optional (i.e. at the discretion of the chemist or supervisor).

g Acceptance criteria for the method blanks performed for radiochemical analysis varies based upon the level of activity in the samples and the amount of background activity. A qualified chemist reviews the data from method blanks to determine if significant contamination is present.

h The acceptance criteria for PCB analyses which are not identified in this table, shall be specified at a later date. Currently, the Analytical Methods Group group leader specifies the QC criteria if different from SW846 and if not specified by the sample generator. 
SUPPLEMENT TABLE A

Volatile Organic Analyses QC Limits

\begin{tabular}{|c|c|c|c|c|c|c|}
\hline$\overline{\mathrm{CAS} \#}$ & Compound & $\begin{array}{c}\text { Precision } \\
\text { (RPD) }\end{array}$ & $\begin{array}{c}\text { Accuracy } \\
(\% \mathrm{R})\end{array}$ & $\begin{array}{c}\text { MDL } \\
\text { (mg/Kg) }\end{array}$ & $\begin{array}{c}\text { PRQL } \\
\text { (mg/Kg) }\end{array}$ & $\begin{array}{c}\mathbf{L C S} \\
(\% \mathrm{R}) \\
\end{array}$ \\
\hline $75-01-4$ & Vinyl Chloride & $\leq 200$ & $\mathrm{D}-251$ & 1 & 4 & D-251 \\
\hline $75-69-4$ & Trichlorofluoromethane & $\leq 110$ & $17-181$ & 1 & 10 & $17-181$ \\
\hline $76-13-1$ & 1,1,2-Trichloro-1,2-2-Trifluoroethane & $\leq 50$ & $60-150$ & 1 & 10 & $60-150$ \\
\hline $75-35-4$ & 1,1-Dichloroethylene & $\leq 250$ & $\mathrm{D}-234$ & 1 & 10 & $\mathrm{D}-234$ \\
\hline $75-9-2$ & Methylene Chloride & $\leq 50$ & D-221 & 1 & 10 & $\mathrm{D}-221$ \\
\hline $75-15-0$ & Carbon Disulfide & $\leq 50$ & $60-150$ & 1 & 10 & $60-150$ \\
\hline $67-66-3$ & Chloroform & $\leq 44$ & $51-138$ & 1 & 10 & $51-138$ \\
\hline $107-6-2$ & 1,2-Dichloroethane & $\leq 42$ & $49-155$ & 1 & 10 & $49-155$ \\
\hline $71-55-6$ & 1,1,1-Trichloroethane & $\leq 33$ & $52-162$ & 1 & 10 & $52-162$ \\
\hline $56-23-5$ & Carbon Tetrachloride & $\leq 30$ & $70-140$ & 1 & 10 & $70-140$ \\
\hline $71-43-2$ & Benzene & $\leq 45$ & $37-151$ & 1 & 10 & $37-151$ \\
\hline $79-1-6$ & Trichloroethylene & $\leq 36$ & $71-157$ & 1 & 10 & $71-157$ \\
\hline $79-0-5$ & 1,1,2-Trichloroethane & $\leq 38$ & $52-150$ & 1 & 10 & $52-150$ \\
\hline $75-25-2$ & Bromoform & $\leq 47$ & $45-169$ & 1 & 10 & $45-169$ \\
\hline $108-88-3$ & Toluene & $\leq 29$ & $47-150$ & 1 & 10 & $47-150$ \\
\hline $127-18-4$ & Tetrachloroethylene & $\leq 29$ & $64-148$ & 1 & 10 & $64-148$ \\
\hline $108-90-7$ & Chlorobenzene & $\leq 38$ & $37-160$ & 1 & 10 & $37-160$ \\
\hline $100-41-4$ & Ethylbenzene & $\leq 43$ & $37-162$ & 1 & 10 & $37-162$ \\
\hline $1330-20-7$ & Xylenes & $\leq 50$ & $60-150$ & 1 & 10 & $60-150$ \\
\hline $79-34-5$ & 1,1,2,2-Tetrachloroethane & $\leq 55$ & $46-157$ & 1 & 10 & $46-157$ \\
\hline $106-46-7$ & 1,4-Dichlorobenzene & $\leq 60$ & $18-190$ & 1 & 10 & $18-190$ \\
\hline $95-50-1$ & ortho-Dichlorobenzene & $\leq 60$ & $18-190$ & 1 & 10 & $18-190$ \\
\hline $60-29-7$ & Ethyl Ether & $\leq 50$ & $60-150$ & 1 & 10 & $60-150$ \\
\hline \multicolumn{7}{|l|}{ Surrogates } \\
\hline & 1,2-Dichloroethane- $d_{4}$ & & $67-131$ & & & \\
\hline & Toluene- $d_{8}$ & & $95-118$ & & & \\
\hline & 4-Bromofluorobenzene & & $90-107$ & & & \\
\hline
\end{tabular}


SUPPLEMENT TABLE B

Nonhalogenated Volatile Organic Analyses QC Limits

\begin{tabular}{|c|l|c|c|c|c|c||}
\hline CAS \# & Compound & Precision (RPD) & $\begin{array}{c}\text { Accuracy } \\
(\% \mathbf{R})\end{array}$ & $\begin{array}{c}\text { MDL } \\
(\mathbf{m g} / \mathbf{K g})\end{array}$ & $\begin{array}{c}\text { PRQL } \\
(\mathbf{m g} / \mathbf{K g})\end{array}$ & $\begin{array}{c}\text { LCS } \\
(\% \mathbf{R})\end{array}$ \\
\hline \hline $67-56-1$ & Methanol & $\leq 50$ & $60-150$ & 10 & 100 & $60-150$ \\
\hline $67-64-1$ & Acetone & $\leq 50$ & $60-150$ & 10 & 100 & $60-150$ \\
\hline $78-93-3$ & $\begin{array}{l}\text { Methyl Ethyl } \\
\text { Ketone }\end{array}$ & $\leq 50$ & $60-150$ & 10 & 100 & $60-150$ \\
\hline $78-83-1$ & Isobutanol & $\leq 50$ & $60-150$ & 10 & 100 & $60-150$ \\
\hline $71-36-3$ & Butanol & $\leq 50$ & $60-150$ & 10 & 100 & $60-150$ \\
\hline $110-86-1$ & Pyridine & $\leq 50$ & $60-150$ & 10 & 100 & $60-150$ \\
\hline Surrogate & & & & & & \\
\hline $71-23-8$ & n-Propanol & & $60-150$ & & & \\
\hline
\end{tabular}

SUPPLEMENT TABLE C Semivolatile Organic Analyses QC Limits

\begin{tabular}{|c|c|c|c|c|c|c|}
\hline CAS\# & Compound & $\begin{array}{c}\text { Precision } \\
\text { (RPD) }\end{array}$ & $\begin{array}{c}\text { Accuracy } \\
(\% \text { R) }\end{array}$ & $\begin{array}{c}\text { MDL } \\
(\mathrm{mg} / \mathbf{K g})\end{array}$ & $\begin{array}{c}\text { PRQL } \\
(\mathrm{mg} / \mathbf{K g})\end{array}$ & $\begin{array}{c}\text { LCS } \\
(\% \mathrm{R}) \\
\end{array}$ \\
\hline $95-48-7$ & 2-Methylphenol & $\leq 50$ & $60-150$ & 5 & 40 & $60-150$ \\
\hline $67-72-1$ & Hexachloroethane & $\leq 44$ & $40-113$ & 5 & 40 & $40-113$ \\
\hline $106-44-5$ & 4-Methylphenol & $\leq 50$ & $60-150$ & 5 & 40 & $60-150$ \\
\hline $98-95-3$ & Nitrobenzene & $\leq 72$ & $35-180$ & 5 & 40 & $35-180$ \\
\hline $121-14-2$ & 2,4-Dinitrotoluene & $\leq 46$ & $39-139$ & 0.3 & 2.6 & $39-139$ \\
\hline $118-74-1$ & Hexachlorobenzene & $\leq 319$ & $\mathrm{D}-152$ & 0.3 & 2.6 & D-152 \\
\hline $87-86-5$ & Pentachlorophenol & $\leq 128$ & $14-176$ & 5 & 40 & $14-176$ \\
\hline $51-28-5$ & 2,4-Dinitrophenol & $\leq 119$ & D-172 & 5 & 40 & D-172 \\
\hline \multicolumn{7}{|l|}{ Surrogates } \\
\hline \multirow[t]{3}{*}{$367-12-4$} & 2-Fluorophenol & & D-107 & & & \\
\hline & Phenol- $d_{s}$ & & $8-142$ & & & \\
\hline & Nitrobenzene- $d_{s}$ & & $28-117$ & & & \\
\hline \multirow[t]{3}{*}{$321-60-8$} & 2-Fluorobiphenyl & & $24-144$ & & & \\
\hline & 2,4,6-Tribromophenol & & D-100 & & & \\
\hline & Terphenyl- $\mathrm{d}_{14}$ & & D-226 & & & \\
\hline
\end{tabular}




\section{APPENDIX B}

This section includes a table of information that may be of value to the data users. Table B1 includes the total mass and/or activity for some of the major species in the sludge of general interest to the data users. 
Table B1 Total Mass and Activity for Selected Species of Interest in Sludge

\begin{tabular}{|c|c|c|c|c|c|c|}
\hline \multicolumn{2}{|l|}{ Measurement } & C1-East & C1-West & C2-East & C2-West & \\
\hline \multicolumn{6}{|c|}{ Summary of tank volumes and sludge mass } & \\
\hline \multicolumn{6}{|c|}{ Volume of Supernatant $\quad$ (L) } & \\
\hline Volume of Sludge & $(\mathrm{L})$ & 5680 & 5680 & 17030 & 17030 & \\
\hline Density of Sludge & $(\mathrm{Kg} / \mathrm{L})$ & 1.561 & 1.541 & 1.479 & 1.501 & \\
\hline Mass of Sludge & $(\mathrm{Kg})$ & 8866 & 8753 & 25187 & 25562 & \\
\hline \multicolumn{6}{|c|}{ Concentration of selected species of interest in sludge } & \\
\hline Thorium & $(\mathrm{mg} / \mathrm{Kg})$ & 3990 & 5360 & 3820 & 7490 & \\
\hline Uranium & $(\mathrm{mg} / \mathrm{Kg})$ & 11800 & 17600 & 18400 & 24300 & \\
\hline Plutonium & $(\mathrm{mg} / \mathrm{Kg})$ & 0.48 & 0.61 & 0.90 & 2.22 & \\
\hline${ }^{233} \mathrm{U}$ & $(\mathrm{mg} / \mathrm{Kg})$ & 21.8 & 79.2 & 20.5 & 40.0 & \\
\hline${ }^{235} \mathrm{U}$ & $(\mathrm{mg} / \mathrm{Kg})$ & 26.5 & 53.3 & 50.9 & 80.3 & \\
\hline${ }^{239} \mathrm{Pu}$ & $(\mathrm{mg} / \mathrm{Kg})$ & 0.36 & 0.50 & 0.71 & 1.71 & \\
\hline \multicolumn{6}{|c|}{ Activity for selected species of interest in sludge } & \\
\hline${ }^{90} \mathrm{Sr}$ & $(\mathrm{Bg} / \mathrm{g})$ & 1200000 & 880000 & 890000 & 1400000 & \\
\hline${ }^{137} \mathrm{Cs}$ & $(\mathrm{Bg} / \mathrm{g})$ & 460000 & 700000 & 920000 & 860000 & \\
\hline${ }^{152} \mathrm{Eu}$ & $(\mathrm{Bg} / \mathrm{g})$ & 540000 & 520000 & 1300000 & 1200000 & \\
\hline${ }^{154} \mathrm{Eu}$ & $(\mathrm{Bg} / \mathrm{g})$ & 240000 & 150000 & 380000 & 480000 & \\
\hline${ }^{155} \mathrm{Eu}$ & $(\mathrm{Bg} / \mathrm{g})$ & 39000 & 38000 & 93000 & 98000 & \\
\hline${ }^{233} \mathrm{U}$ & $(\mathrm{Bg} / \mathrm{g})$ & 7760 & 28200 & 7320 & 14300 & \\
\hline${ }^{238} \mathrm{Pu}$ & $(\mathrm{Bg} / \mathrm{g})$ & 6750 & 7470 & 11000 & 14500 & \\
\hline${ }^{241} \mathrm{Am}$ & $(\mathrm{Bg} / \mathrm{g})$ & 4200 & 7500 & 12100 & 12000 & \\
\hline${ }^{244} \mathrm{Cm}$ & $(\mathrm{Bg} / \mathrm{g})$ & 45000 & 35000 & 53000 & 110000 & \\
\hline \multicolumn{6}{|c|}{ Total mass for selected species of interest in sludge } & Range \\
\hline Thorium & $(\mathrm{Kg})$ & 35.4 & 46.9 & 96.2 & 191.5 & $131.6-238.4$ \\
\hline Uranium & $(\mathrm{Kg})$ & 104.6 & 154.1 & 463.4 & 621.2 & $568.1-775.2$ \\
\hline Plutonium & $(\mathrm{Kg})$ & 0.004 & 0.005 & 0.023 & 0.057 & $0.027-0.062$ \\
\hline${ }^{233} \mathrm{U}$ & $(\mathrm{Kg})$ & 0.193 & 0.693 & 0.516 & 1.022 & $0.710-1.716$ \\
\hline${ }^{235} \mathrm{U}$ & $(\mathrm{Kg})$ & 0.235 & 0.467 & 1.282 & 2.053 & $1.517-2.519$ \\
\hline${ }^{239} \mathrm{Pu}$ & $(\mathrm{Kg})$ & 0.003 & 0.004 & 0.018 & 0.044 & $0.021-0.048$ \\
\hline \multicolumn{6}{|c|}{ Total activity for selected species of interest in sludge } & Range \\
\hline${ }^{90} \mathrm{Sr}$ & (Ci) & 287.56 & 208.18 & 605.86 & 967.21 & $893.4-1175.4$ \\
\hline${ }^{137} \mathrm{Cs}$ & (Ci) & 110.23 & 165.60 & 626.28 & 594.14 & $736.5-759.7$ \\
\hline${ }^{152} \mathrm{Eu}$ & (Ci) & 129.40 & 123.01 & 884.96 & 829.04 & $1014.4-952.1$ \\
\hline${ }^{154} \mathrm{Eu}$ & (Ci) & 57.51 & 35.48 & 258.68 & 331.62 & $316.2-367.1$ \\
\hline${ }^{155} \mathrm{Eu}$ & (Ci) & 9.35 & 8.99 & 63.31 & 67.70 & $72.7-76.7$ \\
\hline${ }^{233} \mathrm{U}$ & (Ci) & 1.86 & 6.67 & 4.98 & 9.88 & $6.8=16.6$ \\
\hline${ }^{238} \mathrm{Pu}$ & (Ci) & 1.62 & 1.77 & 7.49 & 10.02 & $9.1-11.8$ \\
\hline${ }^{241} \mathrm{Am}$ & (Ci) & 1.01 & 1.77 & 8.24 & 8.29 & $9.2-10.1$ \\
\hline${ }^{244} \mathrm{Cm}$ & (Ci) & 10.78 & 8.28 & 36.08 & 76.00 & $46.9-84.3$ \\
\hline
\end{tabular}


INTERNAL DISTRIBUTION

1. J.F. Alexander

2. J.S. Baldwin

3. E. C. Beahm

4. C. A. Bednarz

5. J. M. Begovich

6. J. B. Berry

7. D. A. Bostick

8. J. A. Chapman

9. C. W. Chase

10. J. L. Collins

11. T. B. Conley

12. A. G. Croff

13. S. M. DePaoli

14. J. R. DeVore

15. T. L. Donaldson

16. D. D. Ensor

17. L. K. Felker

18. R. K. Genung

19. J. M. Giaquinto

20. T. M. Gilliam

21. R. D. Hunt

22. T. D. Hylton

23. R. T. Jubin

24. J. M. Keller

25. C. M. Kendrick

26. T. E. Kent

27. K. T. Klasson

28. D. D. Lee

29. S. Y. Lee

30. B. E. Lewis

31. A. J. Lucero

32. J. J. Maddox

33. R. C. Mason

34. A. P. Malinauskas

35. A. J. Mattus

36. C. P. McGinnis

37. L. E. McNeese

38. T. P. Mills

39. T. H. Monk

40. J. W. Moore

41. T. W. Morris

42. T. E. Myrick
43. B. D. Patton

44. J. H. Platfoot

45. M. L. Poutsma

46. S. M. Robinson

47. S. T. Rudell

48. T. F. Scanlan

49. F. J. Schultz

50. C. B. Scott

51. M. B. Sears

52. R. D. Spence

53. B. B. Spencer

54. R. C. Stewart

55. J. R. Stokely

56. P. A. Taylor

57. N. A. Teasley, Jr.

58. L. M. Toth

59. J. R. Trabalka

60. J. R. Travis

61. S. D. Van Hoesen

62. J. F. Walker, Jr.

63. J. S. Watson

64. C. F. Weber

65. T.D. Welch

66. J. H. Wilson

67. C. C. Wynn

68. ORNL Laboratory Records, RC

69. Central Research Library

70-71. Laboratory Records (OSTI) 


\section{EXTERNAL DISTRIBUTION}

72. Stan Blacker, MACTEC, 189 Lafayette Dr., Suite C, Oak Ridge, Tennessee 37830

73. William Brewster, FOB, MS-8722

74. Michael Brown, Waste Isolation Pilot Plant, P. O. Box 3090, Carlsbad, New Mexico 88221

75. C. S. Mims, U. S. Department of Energy, 3 Main, Oak Ridge, Tennessee 37830

76. Elizabeth Phillips, U. S. Department of Energy, 3 Main, Oak Ridge, Tennessee 37830

77. Carl Pilj, ORNL, Building 3130, MS-6058

78-87. Gary Riner, U. S. Department of Energy, 3 Main, Oak Ridge, Tennessee 37830

88. Ken Redus, MACTEC, 189 Lafayette Dr., Suite C, Oak Ridge, Tennessee 37830

89. John Harbour, Westinghouse Savannah River Company, Bldg. 773-43A, Aiken, SC 29808 